\title{
Proceedings of the First Annual Northern California Earthquake Hazards Workshop, January 13-14, 2004
}

Edited by Mary Lou Zoback, USGS, Menlo Park, NEHRP Regional Coordinator, Northern California

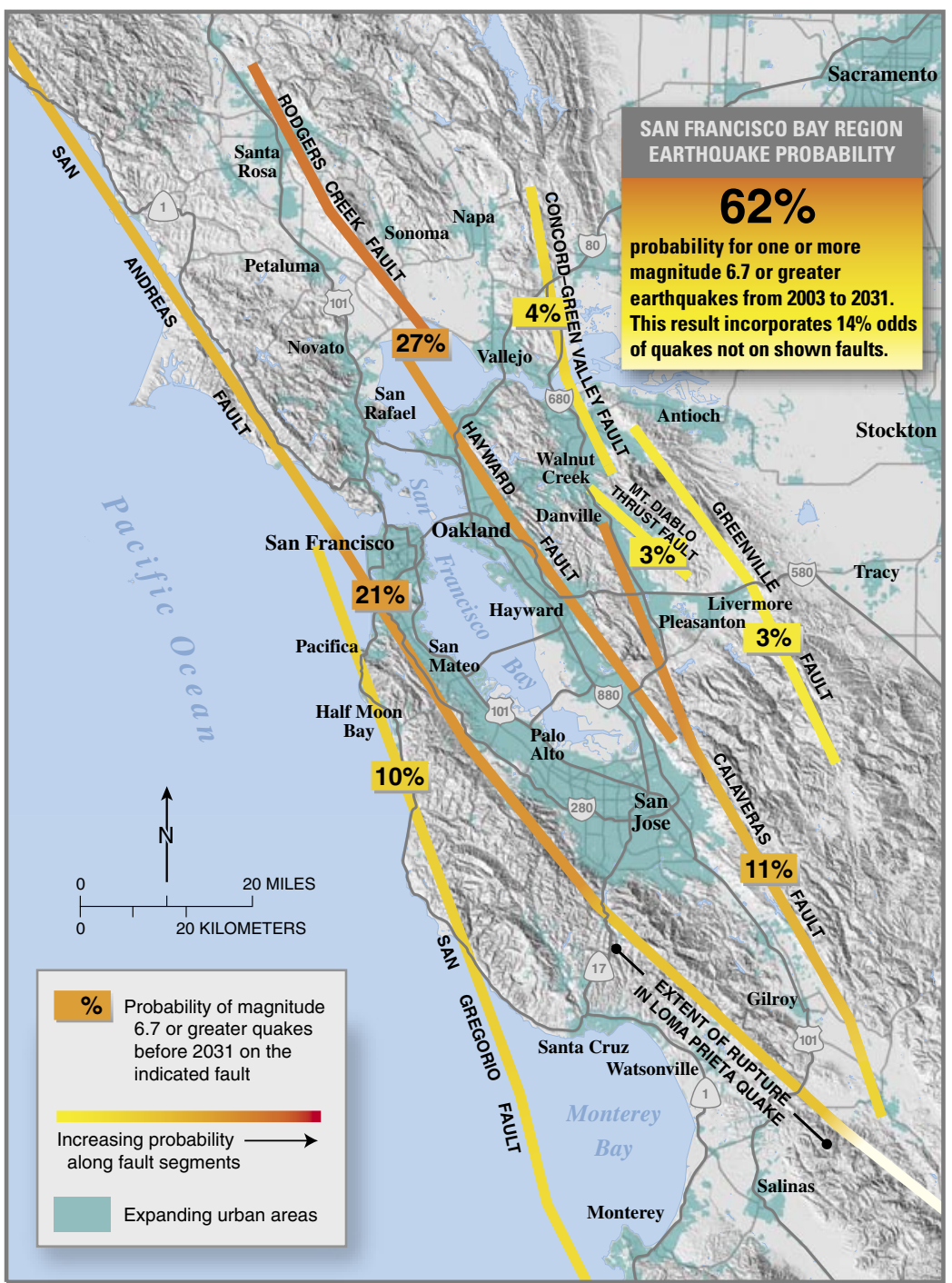

Open-File Report 2004-1424

2004

\section{U.S. Department of the Interior}

\author{
U.S. Geological Survey
}




\section{Contents}

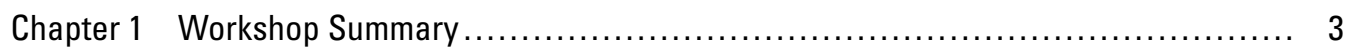

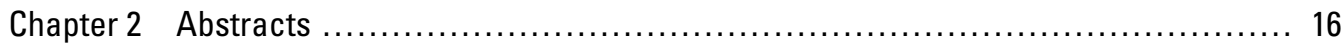

Chapter 3 User Perspective Panel—Synthesis and Individual Presentation Summaries...... 104

Chapter 4 Prospectus for USGS combined Internal and External Earthquake

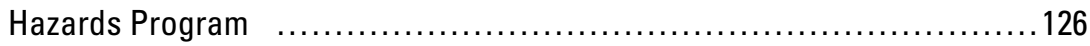

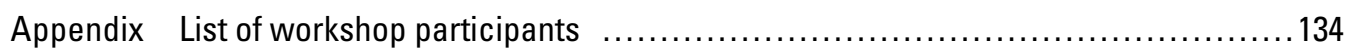




\section{Chapter 1 WORKSHOP SUMMARY}

\section{Introduction, purposes and goals of the workshop}

The USGS Earthquake Hazards Program, as a part of the National Earthquake Hazards Reduction Program (NEHRP), has the broad objectives to:

- Improve earthquake hazard identification and risk assessment methods and their use

- Maintain comprehensive earthquake monitoring with focus on "real-time" systems in urban areas

- Improve the understanding of earthquakes occurrence and their effects and consequences

These objectives are carried out through a number of regional and topical programs. The USGS currently invests about $\$ 7 \mathrm{M} /$ year on earthquake monitoring and hazards research and products for northern California (defined as all of California north of about $35.5^{\circ} \mathrm{N}$, roughly the latitude of Parkfield, CA). Approximately $\$ 1 \mathrm{M} / \mathrm{year}$ of this total supports university and private researchers funded through a highly competitive external grants program designed to complement and expand upon the internal effort.

The first annual workshop on Northern California earthquake hazards sponsored by the USGS NEHRP was held at USGS headquarters in Menlo Park, California on January 13-14, 2004. More than 100 researchers and members of the Northern California user community attended the workshop. Approximately half of the attendees were USGS scientists from Menlo Park and Golden, Colorado, the balance were from the external community.

The purpose of the workshop was multifold:

- increase communication on northern California earthquake hazards issues between internal and external researchers, connect these researchers with the needs of our user community, as well as bring everyone up-to-date on latest research results

- $\quad$ highlight important unresolved questions and issues

- reach a consensus on short- and long-term priorities for hazard and risk reduction products as well as for future research in Northern California.

\section{Format of the workshop and this report}

The workshop was broken into three main parts. The first day and part of the morning of the second day was filled with a series of individual presentations on recent research results followed by updates on large-scale, long-term group efforts and projects. The second part of the workshop was a panel discussion involving members of the user community focused on needs for Northern California earthquake hazard products and research. The user panel included representatives from the utility, water, transportation, mass transit, insurance, and emergency response communities.

To conclude the workshop, researchers and members of the user community were invited to join topical breakout sessions to define major unresolved questions and hazard product 
needs. Between 13 and 29 workshop attendees participated in one of four breakout groups:

1) deformation monitoring and modeling

2) seismic monitoring and 3-D velocity model

3) earthquake effects and hazard products

4) active faulting and Quaternary fault database.

Each breakout group provided a list of short-term (1-3 years) and (longer-term 5+ years) priorities for research and products that were direct input for a combined internal and external prospectus for the northern California earthquake hazards program.

An overview of the USGS-funded northern California earthquake hazard program is given below, followed by a summary of recent research results and status of large group efforts based on the abstracts submitted. For more details, abstracts for both the individual presentations as well as the project updates given at the workshop are included as Chapter 2 together with additional abstracts by researchers unable to attend the workshop. A synthesis of the main points raised in the user perspective panel along with summaries of the individual presentations comprise Chapter 3. Finally, a prospectus for the combined internal and external USGS northern California earthquake hazards program based on the breakout group recommendations is included as Chapter 4. A list of all workshop participants is given in the Appendix.

\section{Overview of the northern California earthquake hazards program}

A recent comprehensive analysis lead by the USGS concluded that the greater San Francisco Bay region has a $62 \%$ likelihood of a major, damaging earthquake (magnitude 6.7 or greater) over the next 30 years (Working Group on Northern California Earthquake Probabilities, 2003). Exposure in the greater Bay Region to this high level of hazard translates to a predicted $\$ 1 \mathrm{~B} /$ year annualized loss due to earthquakes, roughly $25 \%$ of the estimated annualized earthquake losses for the entire United States (FEMA, 2000). These statistics provide a compelling rationale to focus additional research and develop new earthquake hazard products for Northern California. Furthermore, our strong working relationships with the broad user community in northern California-including transportation, utilities and water, emergency response, and earthquake insurance sectors as well as state agencies and local governments - helps assure that our research and hazard products are utilized in local- to state-level planning and policy decisions.

Northern California provides an unprecedented opportunity for major advances in the USGS' NEHRP research, monitoring, and hazard assessment efforts for several reasons:

- It is one of the most densely-sampled (geologically and geophysically) active seismic region in the country. Our sustained effort in studying the seismicity, geology, structure and tectonics of northern California has built a substantial knowledge base.

- The USGS NEHRP investment in northern California is leveraged by sustained complementary and contributory efforts by other USGS programs-particularly the National Geologic Mapping and Coastal and Marine Programs ( \$1.6M/year). 
- Active collaborations with partners at California Geological Survey, Pacific Earthquake Engineering Research center (PEER), California Governor's Office of Emergency Services (OES), FEMA, DOE's Lawrence Livermore Laboratory, and the university and consulting communities.

- New high-density, state-of-the-art seismic, geodetic, and borehole strainmeter data will be soon be available for central and northern California as a result of the NSF-funded EarthScope program, a new major research equipment (MRE) initiative in earth sciences ( $\$ 220 \mathrm{M}$ over 10 years, http://www.earthscope.org)

These factors combined with the tectonic setting of northern California makes the region an ideal natural laboratory to address major NEHRP science questions:

- Coefficient of variation/recurrence interval-A concerted multi-year paleoseismological effort to develop thousand plus year records of past earthquakes on the major faults is yielding valuable data on their long-term behavior.

- Fault zone structure and near-fault ground motions-Dense seismic coverage along the multiple, well-defined traces of major faults offer the opportunity to constrain these critical parameters.

- Role of creeping faults-Northern California has the largest number and distribution of faults with aseismic slip, their influence on the strain release budget is being examined.

- Soil non-linearity-The dense sampling of the shallow subsurface structure by coreholes and cone-penetrometer studies, high resolution seismic refraction and reflection profiles, and a dense strong motion monitoring network provides an ideal opportunity to obtain the necessary data to test theoretical models of the non-linearity of soils

- Fault communication and stress shadows--The close spacing and subparallel nature of the major active faults make this an ideal locality to test theories on fault interactions and viscoelastic effects on stress transfer.

- Strain partitioning - Though the Bay region is dominated by strike-slip fault systems, it appears that roughly one tenth of the total deformation rate is accommodated on a number of subparallel compressional faults whose slow rates of deformation (relative to strike-slip faults) provide a challenge to recognize and accurately assess their hazard

- Precursory phenomena-the combination of dense surface networks of earthquake monitoring systems, borehole instrumentation, and the planned deployment of EarthScope monitoring systems will allow us to continue to search for temporal changes that might indicate imminent future activity.

All of the above reasons combined with significant recent scientific advances make this a critical time to focus earthquake hazards work in Northern California. Furthermore, the upcoming centennial anniversary of the 1906 earthquake will focus the region's and the nation's attention on earthquake science and engineering and provide an unprecedented opportunity to promote public education on hazard products, preparedness, mitigation, and risk reduction. 


\section{Summary of recent results, major-ongoing projects and hazard products in North- ern California}

The recently released San Francisco Bay Region Earthquake probability (Working Group on California Earthquake Probabilities-WGEP, 2003) synthesized a wealth of new data and information for the greater Bay Region. The Working Group devoted considerable effort to defining and quantifying uncertainties in all data, models, and parameters used in their analysis. Their sensitivity analysis indicated a number of unresolved scientific issues strongly impacting the probability uncertainties, including:

- $\quad$ effect of stress shadows and the importance of fault interaction and viscoelastic effects

- creep behavior at depth and its relationship to earthquakes

- coefficient of variation for earthquake recurrence

- "strength" and apparent persistence of segment boundaries

These major sources of uncertainties are already guiding research priorities in northern California as indicated by results presented at the workshop (and in abstracts submitted by those unable to attend), the research results are summarized below by topic. In addition, significant research continues on developing the capabilities and methodologies to quantitatively predict earthquake effects. For more detail, the reader is referred to specific abstracts in Chapter 2. These are referenced below by the abstract's author name(s) in italics in parentheses. References to published papers are given in regular type and format.

\section{Source characterization including building a Quaternary fault map and database}

Numerous studies have been carried out in northern California to address the location, size and frequency of past earthquakes. A major goal moving forward will be to create a Quaternary fault map database for northern California (Graymer) that will synthesize the most recent geologic mapping of active fault traces (1:24,000 when available), paleoseismological information, as well as geophysical data on 3-D fault geometry. The initial product, to be released in April 2006-coinciding with the 1906 centennial, will focus on the grater San Francisco Bay region, including Santa Cruz and Monterey Counties. This fault map database will be part of the USGS National Quaternary fault database.

The Bay Area Paleoseismology Experiment (BAPEX) was initiated in 1998 with the goal of developing a 2000+ year chrononology of large earthquakes on the major strike-slip faults of the region (Schwartz). To date BAPEX has yielded significant new data on the spatial-temporal pattern of past seismic activity relevant to the coefficient of variation of the recurrence interval, timing of stress shadows and fault interactions, as well as the long-term behavior of creeping faults. A major observation from the BAPEX results is that during a maximum interval of 176 years (from 1600 to $1776 \mathrm{AD}$ at 2-sigma) significant seismic moment was released in the greater San Francisco Bay region by large surface faulting events $(M>=6.7)$ on nearly all the major faults. This suggests that at the beginning of the historical period ( 1776 AD, founding of Mission Delores in San Francisco) the region had 
released most of its strain and there was a roughly 60 year period of quiescence before the M 7 earthquake thought to be on the Peninsula segment of the San Andreas.

Long paleoearthquake chronologies have been obtained for the southern Hayward fault where the data indicate a mean recurrence interval of $195 \pm 15 \mathrm{yr}$ over the past 2000 years (Lienkaemper et al.; Williams and Lienkaemper) and for the San Andreas north of San Francisco where a 2500 year record suggests recurrence intervals ranging from 130 to 300 years (Niemi et al.). In contrast, a 1000-year record from two trenches on the San Andreas fault south of the Peninsula near Watsonville has yielded a mean recurrence interval of only 105 years (Fumal), this is half the recurrence interval used by the Working Group in 2002 for this segment of the San Andreas fault.

An even longer earthquake chronology (6000-10,000 years) is being developed for the San Andreas fault in northern California by correlation of turbidite chronology across submarine channels on the adjacent continental shelf (Goldfinger et al,). Detailed core analysis and dating have just begun and preliminary results suggest 35 earthquakes in the last 6200 years, roughly a third of which seem to rupture the entire 1906 segment. Paleoseismic data on the San Andreas near Point Arena suggest the penultimate earthquake, occurred in the mid 1600's and offsets suggest it was comparable in magnitude to 1906 (Baldwin et al.). The offshore turbidite data also bear on source characterization by suggesting a possible additional segment boundary between Point Reyes and Point Arena. Interestingly, a paleoseismic study on the San Andreas near Fort Ross (Prentice et al.), located approximately halfway between Point Reyes and Point Arena, suggests the fault there has a significantly lower slip rate $(18 \pm 3 \mathrm{~mm} / \mathrm{yr})$ than that assumed by the Working Group $(24 \pm 3 \mathrm{~mm} / \mathrm{yr})$. A newly collected Lidar dataset (acquired in collaboration with NASA) is yielding valuable bare-earth topographic information for analysis of geomorphic features along the heavily forested north coast San Andreas fault and along uplifted marine terraces (Prentice et al.). Ultimately, this dataset may help constrain possible segment boundaries along this stretch of the San Andreas as well as provide numerous slip-rate estimates.

Significant new paleoseismologic data for other northern CA faults include: timing of past events on the northern San Gregorio (Koehler), a slip rate and timing of the most recent earthquake on the Maacama (Prentice et al.), evidence for multiple surface-rupturing events on the Green Valley fault in the past 2700 years (Borchardt and Baldwin), and recognition of and approximate slip rate for three major faults beneath Lake Tahoe with significant Holocene activity (Seitz). Near Santa Rosa, where there is a complex right-releasing stepover between the Rodgers Creek and Maacama faults, data indicate an aggregate slip rate between 12-15 mm/yr over the past 2.0-2.5 MA. Over time, three extensional basins have formed to accommodate deformation this complex region that contains faults with the potential for earthquakes between magnitude 5.7 to 6.9 (McLaughlin and Sarna).

Quantification of the seismic potential of thrust faulting in the greater Bay Area remains a major knowledge gap. Working Group 02 characterized only one thrust source zone, the blind thrust beneath Mt. Diablo, but recognized that events on other thrust faults contribute to the regional earthquake probability in the form of background earthquakes. 
The Working Group assessed a 30-yr probability of 14\% for a M6.7 or greater earthquake in the "background", compared to the $62 \%$ overall regional $30-y r$ probability (WGEP, 2003).

Numerous geologic and geomorphic studies have increased our knowledge of the ongoing compressional deformation in northern California. Aerial photography and field reconnaissance suggest that some of the right-lateral slip at the north end of the Green Valley faults is transferred westward to the Maacama fault across constructional structures in the Howell Mountains (Baldwin and Unruh). Similarily, detailed geomorphic mapping and analysis of the region between the San Andreas and Rodgers Creek faults in the northern San Francisco Bay area have indicated localized late Quaternary warping and uplift, probably the result of on-going compressional deformation between the two strikeslip faults (Hitchcock and Kelson).

In the south Bay region, detailed mapping of Quaternary deposits and deformed surfaces along the largely blind frontal thrust fault system east of the San Andreas near Palo Alto suggest an uplift rate of approximately $0.6-0.7 \mathrm{~mm} / \mathrm{yr}$ over the last 4400 years across one strand, the Stanford fault zone (Bullard). On the other side of the Bay, stream terrace profiling and geomorphic mapping suggest that the East Valley thrust system (eastern Santa Clara Valley at the southern end of the Hayward fault) experiences only minor offset (Hitchcock and Brankman). Rather than providing a link between the left step between the Hayward and Calaveras faults, they suggest that this fault system may not be a fully independent earthquake source, and instead may only rupture in secondary response to large earthquakes on either the Hayward and Calaveras faults.

Potential field data combined with accurately relocated seismicity have proven extremely valuable in defining the location and subsurface geometry of faulting. Distinct gravity and magnetic anomalies correlate with mapped mafic and ultramafic rocks along the entire length of the Hayward fault (Ponce et al.). Near San Leandro, the modern trace of the Hayward fault appears to follow the lower, steeply-dipping $\left(\sim 75^{\circ} \mathrm{E}\right)$ boundary of one of these gabbro bodies. A 40-km-long gravity low at the southern end of the Hayward fault delineates the Evergreen basin that sits between the Hayward and subparallel Silver Creek fault zone. Presently the basin boundaries are characterized by steeply-dipping reverse faults, however the basin has been interpreted as forming in a transtensional right-step that was superceded by a transpressional left-step related to the CalverasHayward fault junction (Jachens et al.). The proposed early transtensional evolution of the Evergreen basin suggests there may have been more than $100 \mathrm{~km}$ offset on the Silver Creek fault, a fault that now appears dormant. Detailed analysis of relocated seismicity (from double-difference technique) has illuminated subsurface structure along the Hayward and Calaveras faults (Simpson et al.). Below $6 \mathrm{~km}$ depth the central Calaveras fault appears to connect to the southern Hayward fault through several straight, nonvertical segments. Above $6 \mathrm{~km}$ depth the connection is complex and not well-defined by seismicity. Further south along the central Calaveras the fault appears to consist of several active subparallel strands the upward projection of which deviate from the mapped surface trace. 


\section{Deformation monitoring and modeling}

The stress shadow of the 1906 earthquake and uncertainty about its effects at present and into the future is perhaps the biggest issue impacting the accuracy of time-dependent probability in the Bay region. Recent viscoelastic modeling of the stress interaction of all magnitude 5.8 and larger earthquakes since 1838 suggests that the region emerged from the 1906 "shadow" about 1980, consistent with the acceleration in regional seismicity at that time (Pollitz). A similar conclusion about the timing of emergence from the Bay Area stress shadow was obtained using a somewhat different finite element simulation of post 1906 stress recovery (Parsons).

Modern geodetic monitoring within the United States was pioneered by the USGS in northern California. Deformation has been monitored by the USGS since the 1960's in six transects across the Bay area as well as in measurements near Point Arena and Cape Mendocino, these surveys were originally carried out by theodolite and now by survey-mode GPS ( $J$. Murray et al.). In addition, UC Berkeley has been monitoring numerous profiles throughout northern California since the early 1990's. These data have been critical in helping constrain slip-rate estimates for Bay Area faults. Interpretation of a 68 monument array spanning the Coast Ranges resurveyed by GPS eight times between 1993-2001 yielded a uniform simple shear rate of $38.7 \pm 1.2 \mathrm{~mm} / \mathrm{yr}$ in a $\mathrm{N} 29^{\circ} \mathrm{W}$ direction (Savage et al.). The similarity of this result with the vector sum of the slip rates assigned by Working Group 02 together with the absence of significant areal dilation is interpreted to indicate that major strain release is not required on reverse faults within the Coast Ranges subparallel to the San Andreas fault.

The Bay Area Regional Deformation (BARD) network, a collaborative effort between U.C. Berkeley and the USGS, has been operational for over a decade and now includes close to 70 continuous GPS stations. This network helps constrain the broad-scale deformation patterns across northern California, including the motions of the Sierra-Great Valley block and the San Andreas fault system (M. Murray). These data have been integrated with campaign geodetic results in the Bay Area Velocity Unification (BAVU) project developed at UC Berkeley that has produced a map of Bay Area crustal velocities and slip rates on major faults by analyzing all available data in a self-consistent manner using a 3-D block model (d'Alessio et al., 2005).

Deployment of additional continuous GPS stations in northern California as a part of the EarthScope Plate Boundary Observatory (PBO) provides the opportunity for real-time or near real time analysis of the data stream to search for possible temporal variations of strain and to enable rapid assessment of coseismic slip and associated finite fault models (Murray et al., and Murray). In addition, the role for more traditional survey-mode GPS will likely change, such measurements could provide increased spatial coverage to better constrain the convergent component of motion, monitor likely blind thrusts, and improve resolution of fault slip rates at depth (Murray et al.)

In addition to the measurements of surface deformation, the USGS also pioneered and has carried out for more than 25 years high precision monitoring of borehole strain and 
deformation in northern California. Currently faults in the Bay area are monitored by five USGS borehole dilatometers, five 3-component borehole strain meters installed as part of a (described in the next paragraph), and one 3-component borehole designed and maintained by Mick Gladwin with funding through the USGS NEHRP external program.

A prototype cluster of five seismic and derformation instrumented borehole sites have been installed in the Bay Area as part of planning for the NSF-MRE EarthScope Plate Boundary Observatory. This "mini-PBO" cluster was a collaborative effort between the USGS, UC Berkeley and the Carnegie Institution. Each $200 \mathrm{~m}$ deep borehole was equipped with a tensor strainmeter, seismometer, pore pressure transducer, tiltmeter, surface GPS, and temperature monitor (Johnston et al. ). Initial results indicate that: 1) the total moment release in local earthquakes down to magnitude 3 can be determined from borehole strain offsets, 2) constraints can be placed on the geometry and depth of both surface creep and deep slip, and 3) the timescale and size of earthquake nucleation can be constrained (Johnston et al.). Reliable heat flow values were also determined in 4 of the 5 Bay Area mini-PBO boreholes. Heat flows determined ranged from $78-92 \mathrm{~mW} /$ $\mathrm{m}^{2}$, consistent with previous measurements of elevated heat flow throughout the Coast Ranges in the Bay Area (average heat flow for the 4 sites together with 12 previous sites is $87 \pm 8 \mathrm{~mW} / \mathrm{m}^{2}$ ).

Borehole strain monitoring monitoring will be greatly intensified as a result of PBO. In order to take full advantage of this new array for USGS earthquake hazard program goals, we must enhance and better document their automated data processing, more completely compile all the existing strain data (collected both internally and externally), and develop a state of readiness with respect to interpreting borehole strain, creep, and fluid pressure, as well as a plan for real-time interpretation of such data (Roeloffs).

The Bay Area is unique in containing probably the highest density of creeping strike-slip faults in the world. A surface fault creep-monitoring program involving resurveying of alignment arrays was created by Jon Galehouse at San Francisco State in 1979 and has been funded by the USGS NEHRP external program since its inception. The project is now lead by John Caskey and Karen Grove of San Francisco State and has been carried out in close colloboration with Jim Lienkaemper at the USGS. Creep is being monitored every 23 months by theodolite surveys at over 30 sites around the Bay region (Caskey et al.). The data show that the character of creep varies between gradual deformation and episodic, relatively rapid creep events and also that surface creep is sensitive to both dynamic and static post-earthquake stress changes. A website is currently under development at UCSF to make the creep data publicly available.

The relationship between creep and aligned streaks of repeating microearthquakes has been established for the central San Andrea fault near San Juan Bautista. Joint inversion of near fault deformation measured by GPS and InSAR for fault slip showed astrong correspondence between fault patches with steady secular creep and regions of abundant microseismicity (Johanson and Burgman). 


\section{Seismic Monitoring}

Formation of the California Integrated Seismic Network (with UC Berkeley, Caltech, CGS, and CA OES) in 2000 has resulted in a statewide seismic monitoring system with redundancy between northern and southern California as well as a direct tie to the state Office of Emergency Services (Oppenheimer and Gee). Through coordination with CGS and the USGS National Strong Motion Program, approximately100 new digital strong motion stations have been installed in the greater San Francisco Bay Area and two recently retrofit buildings have been instrumented, all as part of the USGS's Advanced National Seismic System (ANSS) (Savage et al.). All the new ANSS strong motion stations are connected by dial-up or real-time telemetry to allow production of ShakeMap for the greater Bay region within minutes of significant events. The new stations are also greatly increasing the database of ground motions for moderate-sized events.

The100 new ANSS stations are complemented by deployment of 13 low cost strong motion sensors, the TREMOR array, developed as part of USGS Project Impact in Oakland. This array has resulted in Oakland being one of the most densely instrumented urban centers in the United States, with an average spacing of $3 \mathrm{~km}$ (Evans et al.). The TREMOR sensors send peak accelerations, peak velocities, and response spectral amplitudes at three periods in a data packet that arrives within 90 seconds of trigger time. They have successfully recorded a number of small to moderate size events (M3.4-4.7). The San Jose Dense Seismic Array consists of 45 accelerometers with a spacing of about $1 \mathrm{~km}$ deployed in a band from downtown San Jose eastward across the Evergreen Basin. To date about 40 earthquakes have been recorded on 30 or more stations and are being used to determine basin effects and site response (Frankel et al.).

Seismic and geodetic deformation monitoring data are publicly available through the Northern California Earthquake Data Center, a joint project of the University of Callifornia Berkeley Seismological Laboratory and the United States Geological Survey (Gee and Oppenheimer). The datasets include earthquake catalogs, seismograms, GPS time series, and other geophysical data sets including strain, tilt, and creep. A major effort is underway to convert waveform data to MiniSEED format and to put earthquake catalogs into a database format. When these projects are completed, users will be able to access waveform data using a common set of tools and will have integrated access to the earthquake catalogs, parametric, and waveform data.

Analysis of characteristically repeating microearthquake $(\mathrm{M}<3.5)$ locations along a 175 $\mathrm{km}$ segment of the central San Andreas fault directly southeast of the Loma Prieta rupture reveal patterns of quasi-periodic repetition or pulsing of deep aseismic slip events (Nadeau and McEvilly). This extensive, large amplitude, long duration pulsing occurs both in conjunction with and independent of transient slip from larger earthquakes. The pattern of pulsing in the northern part of the study area appears coherently timed over $60-70 \mathrm{~km}$ of fault length and, in fact, the occurrence of the M6.9 1989 Loma Prieta earthquake correlates with one of the pulse onset periods. 
A massive effort to relocate all earthquakes in Northern California using both waveform cross correlation and double difference relative location techniques is currently underway (Schaff et al.) Results to date show a substantially increased level of detail across most of the northern California region and, in particular, well-delineated fault planes.

\section{Subsurface structure, basin effects, and 3-D velocity model}

A wealth of data from urban seismic arrays and several decades of active seismic experiments throughout the Northern California region are being integrated with gravity and magnetic data to define basin structure, build and test models of basin amplification, and delineate young faulting. These data complement numerous site response studies, cone-penetrometer testing in the near surface, and the recent correlation and consistent mapping of Quaternary deposits and liquefaction susceptibility for the greater Bay Area (Knudsen et al., 2000). A major effort in Northern California over the next two years will be to combine all these data with existing geologic mapping to produce an updated 3-D geologic "map/model" and to derive from it a new 3-D velocity model for the region (Jachens; Brocher; Mooney et al.). A new "double-difference" tomographic inversion of earthquake and active source data for northern California will be an important component of the new 3-D velocity model (Thurber and $\mathrm{Du}$ ).

Over the past few years, considerable NEHRP effort has been focused on defining the subsurface structure of the southern San Francisco Bay area (Santa ClaraValley) and the effects of underlying basins on seismic amplification. Contour maps of the top of Pleistocene deposits and Holocene sediment thickness are have been developed for the Southern San Francisco Bay area using compiled subsurface data (Hitchcock and Helley). The top of the Pleistocene unconformity is distinguished by a distinct soil horizon associated with a notable increase in density and changes in color and texture identifiable in geotechnical boring logs. This shallow structural data aid in site characterization and provide a unique strain marker for evaluating the location and style of Holocene deformation along the Bay margins.

The deeper structure of Santa Clara Valley consists of two major basins, the Cupertino basin on the southwest and the Evergreen basin on northeast, separated by a basement high (Wentworth et al.). The Santa Clara Valley is bounded on both sides by outward dipping reverse faults subparallel to the nearby San Andreas and Calaveras faults. Gravity and well log data indicate that the Cupertino basin has an asymmetric structure with beds dipping SW into the bounding reverse fault. It is about 400m deep (depth to the Plio-Quaternary unconformity) and is less than 1 million years old. In contrast, the northeastern Evergreen basin appears to be a pull-apart basin formed between the subparallel Silver Creek and Hayward faults and is filled with flat lying sediments in at least the upper 1+ km. Seismic reflection profiling in the Evergreen basin suggests reverse fault movement on the Silver Creek fault in the Pleistocene (although there is no surface manifestation of fault activity) (Williams et al.) and a $70^{\circ}$ east dip on the Hayward fault in the upper $500 \mathrm{~m}$. Similar profiling in the Cupertino basin reveals primarily horizontal near-surface strata over a prominent angular unconformity. 
Preliminary processing suggests that the Cascade and Santa Clara thrust faults mapped at the surface do displace reflectors at depth (Williams et al.).

Amplification of ground motion across the Evergreen Basin is being studied using the San Jose Dense Array (Frankel et al.). Results to date indicate that ground motions are amplified about a factor of two on the western side of the basin, relative to a reference rock site, over a broad range of frequencies. Waveforms of regional events show large basin surface waves trapped in the basin. Despite preliminary modeling the mechanism for the amplification on the western edge of the Evergreen basin remains unclear. A new 3-D velocity model for Santa Clara Valley will be constructed that is consistent with all available seismic and geologic mapping (Evans et al.).

\section{Hazard mapping and earthquake effects}

The USGS northern California earthquake hazard program has been addressing several generic hazard/earthquake effects topics as well as site-specific studies including a focus on completing a pilot urban hazard assessment project for the city of Oakland. Two of the generic hazard efforts are being conducted in collaboration with PEER: 1) the Next Generation of Attenuation (NGA) project to develop new and consistent ground motion attenuation models for earthquakes in the western U. S. (Boatwright), and 2) development of design-oriented conditional probability models needed for estimating fault rupture hazard within either a deterministic or probabilistic framework (also being done in collaboration with CGS) (Petersen).

Other general hazard studies being conducted in northern California include:

- An analysis of a composite geologic dataset (521 observations from 180 sites) on repeated fault offset has been completed. The results indicate that event-toevent variability in slip at a given point along a fault is less than expected from a Gutenberg-Richter distribution of earthquake sizes and is also less than assumed in fault rupture hazard evaluations (Hecker and Abrahamson).

- Development of a model for predicting site coefficients in building codes based on theoretical solutions for a viscoelastic soil layer over rock. Parameteric analysis of the theoretical solutions shows that average site response characteristics for vertically incident $S$-waves are in good agreement with those currently specified using site class (shear velocity) and base acceleration (Borcherdt).

- Development of a methodology for site hazard zonation by mapping of the thickness and shear wave velocity of near-surface sediments using a spatial autocorrelation of array studies of microtremors. This methodogy will be tested against more traditional (and much more costly) of shallow shear wave studies at a site in the Santa Clara Valley in 2005 (Asten).

- Development of a web-based Home Quake Safety Toolkit that provides information on both structural and non-structural hazards and mitigation, as well as on family disaster plans by the Association of Bay Area Governments (ABAG). ABAG is currently developing Tools for Businesses to Tame Disaster that will be released in the late winter of 2004 or early spring of 2005 (Perkins). 
- An evaluation of whether the location and magnitude of earthquake-induced lateral spreading might be a predictable phenomenon subject to eptistemic uncertainty (rather than occurring randomly within an area of high liquefaction susceptibility). The first phase of this evaluation was an investigation in Watsonville of site of possible repeatability of lateral spreading associated with liquefaction along a stratigraphic boundary (Thompson et al.)

In January 1998, the city of Oakland, California was named by FEMA as one of seven pilot "Project Impact" communities. The goal of this program was to help communities assess their vulnerability and prepare for natural disasters. In a collaborative effort with the Oakland Office of Emergency Services, the California Geological Survey, and EQE International the USGS developed hazard assessments for earthquake ground shaking, liquefaction, and landslides (Boatwright). Oakland, a city with complex distribution of young, poorly consolidated sediments and which sits astride one of the most hazardous faults in the region, the Hayward fault was an excellent pilot study for such an urban hazard assessment.

The effort began with an accelerated geologic map compilation of nine 7.5" quadrangles (Graymer et al., 1996) to create a digital geologic base for all the hazard studies. More than 210 sites were sampled in Oakland and the neighboring island of Alameda using a Cone Penetrometer Truck to determine the strength and shear velocity of the near surface sediments and construct a 3D geologic map of near surface units (Holzer et al., 2002). Maps of shaking hazard (Hand et al., 2004), liquefaction potential index (Holzer et al., 2002), and seismic landslide hazard (Miles and Keefer, 2001) were produced for a scenario M7.1 rupture of the entire Hayward fault. In addition, a geologic (non-seismic trigger) landslide susceptibility map was also developed (Pike et al., 2001).

\section{References}

d'Alessio, M.A., Johanson, I. A., Burgmann, R., Schmidt, D.A., and Murray, M. H., 2005, Slicing up the San Francisco Bay Area: Block kinematics and fault slip rates from GPS-derived surface velocities. Journal of Geophysical Research, doi:2004JB003496. http://www.seismo.berkeley.edu/ burgmann/RESEARCH/BAVU/

FEMA, 2000, HAZUS99 Estimated Annualized Earthquake Losses for the United States: FEMA 366, available on the web at:

Graymer, R.W., Jones, D.L., and Brabb, E.E., (1999), Preliminary geologic map emphasizing bedrock formations in Alameda County, California: a digital database: USGS OpenFile Report 96-252, http://geology.wr.usgs.gov/open-fine/of96-2521.

Hand, E, K., Boatwright, J., and Silva, W. (2004) A sensitivity analysis of ground motion in Oakland for a Hayward fault earthquake, Bull. Seism. Soc. Am. (submitted). 
Holzer, T.L., Bennett, M.J., Noce, T.E., Padovani, A.C., and Tinsley, J.C., III, (2002). Liquefaction hazard and shaking amplification maps of Alameda, Berkeley, Emeryville, Oakland, and Piedmont: A digital database: U.S. Geological Survey Open-file Report 02-296.(http://geopubs.usgs.wr.gov/open_file/of02-296). For CPT data access, and related articles see: http://quake.usgs.gov/prepare/cpt/alameda.htm

Knudsen, K. L., Sowers, J. M., Witter, R. C., Wentworth, C. M., and Edward J. Helley, 2000, Preliminary maps of Quaternary deposits and liquefaction susceptibility, ninecounty San Francisco Bay region, California: a digital database: U. S. Geological Survey Open-File Report, 00-444, http://geopubs.wr.usgs.gov/open-file/of00-444).

Miles, S.B., and Keefer, D.K.(2001) Seismic landslide hazard for the cities of Oakland and Piedmont, California: USGS MF Map 2379, 1 sheet, scale 1:24,000, http://geopubs. wr.usgs.gov/map-mf/mf2379

Pike, R. J., Graymer, R. W., Roberts, S.,Kalman, N.B., and Sobierszczyk, S. (2001). Map and map database of susceptibility to slope failure by sliding and earthflow in the Oakland area, California: USGS MF Map 2385, 37 pp., http://geopubs.wr.usgs.gov/ map-mf/mf2385.

Working Group on California Earthquake Probabilities, 2003, Earthquake Probabilities in the San Francisco Bay region, 2002-2031: U. S. Geological Survey Open-File Report, 03-214, 187 p., http://geopubs.wr.usgs.gov/open-file/of03-214). 


\section{Chapter 2 Abstracts}

This chapter contains abstracts for all Northern California Earthquake Hazard Workshop presentations, listed alphabetically. In addition, abstracts by USGS-NEHRP funded investigators who were unable to attend the workshop are also included. A complete list of abstracts include is given below, for abstracts with more than two authors, the first author is given along with "et al".

\begin{tabular}{|c|c|}
\hline Asten, M. & $\begin{array}{l}\text { Method for site hazard zonation, Santa Clara Valley: Thickness } \\
\text { and shear-velocity mapping of Holocene-Pleistocene sdeiments } \\
\text { by array studies of microtremors }\end{array}$ \\
\hline Baldwin, J. N. et al. & $\begin{array}{l}\text { Timing of a prehistoric earthquake and estimate of coseismic } \\
\text { displacement of the penultimate earthquake on the northern } \\
\text { San Andreas fault, Pt. Arena, California }\end{array}$ \\
\hline Baldwin, J.N. & $\begin{array}{l}\text { References for NEHRP-funded paleoseismology work in } \\
\text { northern California }\end{array}$ \\
\hline Baldwin, J.N. and Unruh, J. R. & $\begin{array}{l}\text { Neotectonic lineaments and Quaternary folds in the Howell } \\
\text { Mountains, Eastern Napa County, California: restraining } \\
\text { stepover at the northern termination of the Green Valley fault? }\end{array}$ \\
\hline Boatwright, J. & USGS Contributions to Project Impact in Oakland \\
\hline Boatwright, J. & The next generation of attenuation (NGA) relations \\
\hline Borchardt, G. and Baldwin, J. N. & $\begin{array}{l}\text { Late Holocene behavior and seismogenic potential of the } \\
\text { Concord-Green Valley fault system in Contra Costa and Solano } \\
\text { Counties, CA }\end{array}$ \\
\hline Borcherdt, R. D. & $\begin{array}{l}\text { Viscoelastic wave propagation in layered soil deposits: a } \\
\text { theoretical model for site coefficients in building codes }\end{array}$ \\
\hline Brocher, T.M. & $\begin{array}{l}\text { Data Sources for the USGS 3-D velocity model for the San } \\
\text { Francisco Bay Area, California }\end{array}$ \\
\hline Bullard, T. et al. & $\begin{array}{l}\text { Quaternary investigations to evaluate seismic source } \\
\text { characteristics of the frontal thrust belt, Palo Alto region, CA }\end{array}$ \\
\hline Caskey, J. & Bay area creep project \\
\hline Evans, J. R. & Constrained forward modeling for subsurface velocity structure \\
\hline Evans, J. R. et al. & TREMOR and dense networks \\
\hline Frankel, A. et al. & $\begin{array}{l}\text { San Jose Dense Seismic Array: findings to date and future } \\
\text { plans }\end{array}$ \\
\hline Fumal, T. E. et al. & $\begin{array}{l}\text { A 100-yr average recurrence interval for the San Andreas fault, } \\
\text { southern San Francsico Bay Area }\end{array}$ \\
\hline Furlong, K. P. & $\begin{array}{l}\text { Imaging patterns of fault creep: implications for earthquakes } \\
\text { on the Hayward fault }\end{array}$ \\
\hline Gee, L. and Oppenheimer, D. & The Northern California Earthquake Data Center \\
\hline Goldfinger, C. et al. & $\begin{array}{l}\text { A possible long-term paleoseismic earthquake record along the } \\
\text { northern San Andreas fault based on turbidite stratigraphy }\end{array}$ \\
\hline Graymer, R. W. & Northern California active fault map database \\
\hline Hecker, S. and Abrahamson, N. & $\begin{array}{l}\text { Low slip-at-a-point variability: Implications for earthquake- } \\
\text { size distribution, fault rupture hazard, and ground motion } \\
\text { modeling }\end{array}$ \\
\hline Hitchcock, C. S. & $\begin{array}{l}\text { Characterization of subsurface sediments, southern San } \\
\text { Francisco Bay Area, CA }\end{array}$ \\
\hline
\end{tabular}




\begin{tabular}{|c|c|}
\hline $\begin{array}{l}\text { Hitchcock, C. S. and Kelson, K. } \\
\text { I. }\end{array}$ & $\begin{array}{l}\text { Assessment of seismogenic sources between the Rodgers } \\
\text { Creek and San Andreas faults, NW San Francisco Bay Region, } \\
\text { Sonoma County, CA }\end{array}$ \\
\hline $\begin{array}{l}\text { Hitchcock, C.S. and Brankman, } \\
\text { C. M. }\end{array}$ & $\begin{array}{l}\text { Assessment of late Quaternary deformation, E. Santa Clara } \\
\text { Valley, San Francisco Bay region }\end{array}$ \\
\hline Holzer, T. L. et al. & $\begin{array}{l}\text { Quantitative liquefaction hazard maps: San Francisco Bay } \\
\text { Area, CA }\end{array}$ \\
\hline Jachens, R. C. & The 3-D Geologic Map and Visualization Project \\
\hline Jachens, R. C. et al. & $\begin{array}{l}\text { Significant role of the Silver Creek fault in the San Andreas } \\
\text { System, CA }\end{array}$ \\
\hline Johanson, I. A. and Burgmann, R. & $\begin{array}{l}\text { Connecting aseismic slip and microseismicity on the central } \\
\text { San Andreas fault }\end{array}$ \\
\hline Johnston, M. J. S. et al. & $\begin{array}{l}\text { Borehole tensor strain and pore pressure from San Francisco } \\
\text { Mini-PBO sites: initial results and comparison with other } \\
\text { USGS borehole strain and deformation data }\end{array}$ \\
\hline Keefer, D. K. and Miles, S. B. & Earthquake-induced landslides \\
\hline Knudsen, K. & $\begin{array}{l}\text { Priorities and needs for ground failure research--a CGS } \\
\text { perspective }\end{array}$ \\
\hline Koehler, R. D. et al. & $\begin{array}{l}\text { Paleoseismic investigation of the N San Gregorio fault at Pillar } \\
\text { Point Marsh near Half Moon Bay, CA }\end{array}$ \\
\hline Lienkaemper, J. J. & $\begin{array}{l}\text { A } 2000 \text {-year preliminary record of large earthquakes on the } \\
\text { southern Hayward fault }\end{array}$ \\
\hline $\begin{array}{l}\text { McLaughlin, R. J. and } \\
\text { Sarna-Wojcicki, A. }\end{array}$ & $\begin{array}{l}\text { The right-releasing stepover between the Rodgers Creek- } \\
\text { Healdsburg and Maacama fault zones: modeling the evolution } \\
\text { of young pull-apart basins along the northern part of the east } \\
\text { San Francisco Bay strike-slip fault system }\end{array}$ \\
\hline Mooney, W. D. et al. & $\begin{array}{l}\text { Towards an updated 3-D velocity model of the San Francisco } \\
\text { Bay Area }\end{array}$ \\
\hline Murray, J. et al. & Geodetic efforts in northern California \\
\hline Murray, M. H. & Geodetic studies of the northern San Andreas fault system \\
\hline $\begin{array}{l}\text { Nadeau, R. M. and } \\
\text { McEvilly, T. V. }\end{array}$ & Deep aseismic slip transients on the central San Andreas fault \\
\hline Niemi, T. M. et al. & $\begin{array}{l}\text { A 2500-year record of large earthquakes along the northern San } \\
\text { Andreas fault at Vedanta Marsh, Olema, CA }\end{array}$ \\
\hline Oppenheimer, D. and Gee, L. & $\begin{array}{l}\text { The California Integrated Seismic Network (CISN) and } \\
\text { northern CA earthquake monitoring }\end{array}$ \\
\hline Parsons, T. & $\begin{array}{l}\text { USGS Coastal and Marine Program earthquake hazard studies } \\
\text { in northern CA }\end{array}$ \\
\hline Perkins, J. & $\begin{array}{l}\text { Earthquake hazard information for small businesses and } \\
\text { multifamily housing with implications for public policy-San } \\
\text { Francisco Bay area }\end{array}$ \\
\hline Petersen, M. et al. & $\begin{array}{l}\text { Mapping fault rupture hazard for strike-slip earthquakes: a } \\
\text { cooperative study between the USGS, PEER, and CGS }\end{array}$ \\
\hline Pollitz, F. & Stress evolution in the SF Bay region since 1838 \\
\hline Ponce, D. A. et al. & $\begin{array}{l}\text { Geophysical studies along the Hayward fault and their } \\
\text { implications on the geometry and segmentation of the fault, } \\
\text { northern CA }\end{array}$ \\
\hline Prentice, C. et al. & $\begin{array}{l}\text { Paleoseismology along the northern San Andreas and } \\
\text { Maacama faults }\end{array}$ \\
\hline
\end{tabular}




\begin{tabular}{|l|l|}
\hline Prentice, C. et al. & Northern California LIDAR project \\
\hline Roeloffs, E. & $\begin{array}{l}\text { Low-frequency borehole strain monitoring in northern CA: } \\
\text { current status and outlook as EarthScope (PBO) is deployed }\end{array}$ \\
\hline Savage, J. C. & $\begin{array}{l}\text { Strain accumulation across the Coast Ranges at the latitude of } \\
\text { San Francisco, 1994-2000 }\end{array}$ \\
\hline Savage, W. U. & $\begin{array}{l}\text { Implementing the structural monitoring program of the } \\
\text { Advanced National Seismic System (ANSS) }\end{array}$ \\
\hline Schaff, D. P. et al. & $\begin{array}{l}\text { Applying massive waveform cross-correlation and double } \\
\text { difference location to northern CA and China }\end{array}$ \\
\hline Schwartz, D. P. & $\begin{array}{l}\text { The Bay Area Paleoearthquake Experiment (BAPEX) and the } \\
\text { Bay Area Earthquake Cycle }\end{array}$ \\
\hline Seitz, G. & $\begin{array}{l}\text { Closing the gap between on and offshore paleoseismic records } \\
\text { in the Lake Tahoe basin }\end{array}$ \\
\hline Simpson, R. W. et al. & $\begin{array}{l}\text { Structures in the Hayward and Calaveras fault zones inferred } \\
\text { from relocated seismicity }\end{array}$ \\
\hline Thompson, S. C. et al. & $\begin{array}{l}\text { Evaluating the repeatibility of lateral spreading near } \\
\text { Watsonville, CA }\end{array}$ \\
\hline Thurber, C. and Du, W. & $\begin{array}{l}\text { Improving earthquake locations and velocity models in } \\
\text { northern CA }\end{array}$ \\
\hline Wentworth, C. M. et al. & Structure and stratigraphy of the Santa Clara Valley \\
\hline Williams, C. F. and Harris, R. N. & $\begin{array}{l}\text { Opportunities for heat flow and borehole studies with PBO } \\
\text { drilling and results from SF Bay Area miniPBO measurements }\end{array}$ \\
\hline $\begin{array}{l}\text { Williams, P. L. and } \\
\text { Lienkaemper, J. J. }\end{array}$ & $\begin{array}{l}\text { Early paleoearthquake data from Tule Pond, southern Hayward } \\
\text { fault, CA }\end{array}$ \\
\hline Williams, R. et al. & $\begin{array}{l}\text { Seismic reflection images of the Hayward and Silver Creek } \\
\text { faults and the Evergreen and Cupertino basins, southern San } \\
\text { Francisco Bay area, CA }\end{array}$ \\
\hline Zoback, M. L. & Introduction, goals, and purposes of the workshop \\
\hline & \\
\hline
\end{tabular}




\title{
METHOD FOR SITE HAZARD ZONATION, SANTA CLARA VALLEY: THICKNESS AND SHEAR-VELOCITY MAPPING OF HOLOCENE-PLEISTOCENE SEDIMENTS BY ARRAY STUDIES OF MICROTREMORS.
}

\author{
Michael W. Asten \\ Professorial Fellow, School of Geosciences, Monash University, Melbourne, Australia \\ Email: masten@mail.earth.monash.edu.au
}

Characterization of the thickness and shear-strength of unconsolidated sediments is necessary for the computation of site amplification effects which in turn is an essential part of earthquake hazard zonation.

The approach used in this project is to use the Spatial Autocorrelation method (SPAC) of array processing to measure velocity-period dispersion curves of Rayleigh modes of microtremor seismic energy, and invert to layered-earth models of thickness and shear velocity. Particularities of the approach as implemented by this author are (a) direct inversion of autocorrelation coefficients (also known as spatially-averaged coherencies) for layered-earth parameters, and (b) solutions involving novel array design which allow for multi-mode Rayleigh-wave propagation of microtremors.

The objectives of this project are to acquire microtremor data using an array of seismometers from a location or locations where boreholes also exist for sediment and hydrology studies, such as Coyote Creek CCOC and Guadalupe GUAD (Santa Clara Valley Water District). The USGS has an existing program to log such holes for $\mathrm{P}$ and $\mathrm{S}$-wave interval velocities; (such borehole data is treated as an independent data set separate from this project, to be used for verification of results). Microtremor data is to be processed for spatially-averaged coherencies and inverted to yield a best-fit layered-earth model of thicknesses and shear velocities, including parameter sensitivities and bounds, at each site. The parameters derived from the array studies are being compared with the $\mathrm{P}$ and $\mathrm{S}$-wave logs for the purpose of evaluation of accuracy of the inversion method.

Current USGS studies have found that drilling and seismic P-S logging costs of order $\$ 16 \mathrm{~K}$ per site. Seismic cone penetrometer studies are cheaper, but still invasive, and may be blocked by strata of coarse gravels. We anticipate that the results of this project will demonstrate that the non-invasive, passive seismic microtremor observations provide thickness and shear-velocity data of sufficient accuracy to allow computation of site-amplification effects, at a cost at least an order of magnitude cheaper than drilling and logging a hole. Lateral resolution as set by array sizes is on the scale of hundreds of meters, consistent with the needs for site hazard mapping at a scale of 1:24,000. This result will have large implications for the cost and ease of both regional and site studies of site amplification as required for earthquake hazard zonation.

$* * *$ 


\title{
TIMING OF A PREHISTORIC EARTHQUAKE AND ESTIMATE OF COSEISMIC DISPLACEMENT OF THE PENULTIMATE EARTHQUAKE ON THE NORTHERN SAN ANDREAS FAULT, CALIFORNIA
}

\author{
John N. Baldwin ${ }^{(1)}$, Keith L. Knudsen ${ }^{(2)}$, Carol S. Prentice ${ }^{(3)}$ Aletha Lee $^{(4)}$, Ralf Gross ${ }^{(5)}$ \\ ${ }^{(1)}$ William Lettis \& Associates, Inc.; 1777 Botelho Drive, Suite 262; Walnut Creek, CA 94593 \\ (925) 256-6070, fax (925) 256-6076; e-mail: baldwin@ lettis.com \\ ${ }^{(2)}$ Now at California Division of Mines and Geology, 185 Berry Street, Suite 210, San Francisco, \\ CA, kknudsen@conserv.ca.gov \\ ${ }^{(3)}$ United States Geological Survey; 345 Middlefield Road, MS 977; Menlo Park, CA 94025 \\ cprentice@ isdmnl.wr.usgs.gov \\ ${ }^{(4)}$ West Virginia University; Geology Department; Morgantown, WV 26505; alee@WVU.edu \\ ${ }^{(5)}$ Institute of Geophysics; ETH-Honggerberg, CH-8093; Zurich, Switzerland \\ ralfgross@aug.ig.erdw.ethz.ch
}

Earthquake-timing data from paleoseismic investigations on the northern San Andreas fault (SAF) permit the interpretation that an earthquake, perhaps similar to the 1906 earthquake, occurred in the mid-1600's; however, no information is available on the amount of coseismic slip during this mid-1600 event. At the Alder Creek trench site near Point Arena, California, we collect earthquake timing data, and develop coseismic slip information for the penultimate earthquake on the northern SAF. Based on trench exposures of stratigraphic and structural relations, a poorly-constrained prehistoric earthquake occurred at the site between AD 680 to AD 1630. The trenches also exposed the western margin of a paleochannel that is right-laterally offset a minimum of $8.5 \pm 0.5 \mathrm{~m}$ to a maximum of $9.0 \pm 0.5 \mathrm{~m}$ by the SAF. Radiometric ${ }^{14} \mathrm{C}$ data provide an average maximum age of $490 \pm 20 \mathrm{yr}$ BP for the offset paleochannel.

Using earthquake timing data from the Scaramella Ranch (1.7 km southeast of Alder Creek site), that suggests the penultimate earthquake occurred after AD 1640, the offset paleochannel at Alder Creek likely records coseismic surface displacement from two events: the 1906 and penultimate earthquakes. About $4.9 \mathrm{~m}$ of surface displacement was measured in 1906, $1.2 \mathrm{~km}$ southeast of Alder Creek. The displacement associated with the penultimate earthquake is the difference between the total offset of the paleochannel ( 8 to $9.5 \mathrm{~m}$ ) and the coseismic surface displacement $(4.9 \mathrm{~m})$ observed after the 1906 earthquake. This analysis includes at least three assumptions: (1) the penultimate earthquake ruptured the surface at the site; (2) the paleochannel has been displaced by only two events; and (3) the displacement occurred along the main fault zone. The trench data suggest that the penultimate earthquake displaced the $490 \pm 20 \mathrm{yr}$ old paleochannel between 3.1 to $4.6 \mathrm{~m}$, and was similar in magnitude to the 1906 earthquake.

$* * *$ 


\title{
NEOTECTONIC LINEAMENTS AND QUATERNARY FOLDS IN THE HOWELL MOUNTAINS, EASTERN NAPA COUNTY, CALIFORNIA: RESTRAINING STEPOVER AT THE NORTHERN TERMINATION OF THE GREEN VALLEY FAULT?
}

\author{
John N. Baldwin and Jesse R .Unruh \\ William Lettis \& Associates, Inc., 1777 Bothelho Dr., Suite 262, Walnut Creek, CA 94596, 510- \\ 256-6070; baldwin@lettis.com; unruh@lettis.com
}

The Green Valley fault (GVF) is an active 30-km-long strike-slip fault within the eastern San Andreas system north of Suisun Bay with an average creep rate of about $5.5 \mathrm{~mm} / \mathrm{yr}$. Prominent geomorphic expression of the fault terminates abruptly within a massive landslide complex in Wooden Valley. Although workers have suggested that the continuation of the fault north of Wooden Valley lies along a NW-trending alignment of seismicity that can be traced to the Clear Lake area and the southern end of the Bartlett Springs fault, evidence for late Quaternary surface faulting is discontinuous along this trend. Based on analysis of aerial photography and field reconnaissance, we propose that at least some of the slip on the GVF may be transferred westward in a restraining stepover to the Maacama fault, and accommodated by contractional deformation in the Howell Mountains west of Wooden Valley. We map two prominent northwest-trending lineament zones northwest of the GVF in the Howell Mountains, herein named the Foss Valley-Atlas Peak and Snow Flat-Lake Hennessey zones. The lineaments cut across Pliocene Sonoma Volcanics and Cretaceous Franciscan rocks and are expressed by tonal contrasts, springs, scarps, apparent offset of volcanic units, and aligned drainages, notches, linear troughs, sidehill benches and ridges. Field reconnaissance reveals that the lineaments locally correlate with poorly-developed shear zones, probable thrust faults and small-amplitude folds within the Sonoma Volcanics. The lineaments regionally are associated with a series of westnorthwest-trending asymmetric, southwest-vergent folds in the Howell Mountains that include the Conn Creek anticline and Foss Valley syncline. Individual folds are approximately $8 \mathrm{~km}$ or more in length and locally exhibit several $\mathrm{km}$ of structural relief on the Sonoma Volcanics. The lineaments, faults and folds in the Howell Mountains can be traced from the northern GVF westnorthwest to eastern Napa Valley, and they appear to be on trend with a series of SW-vergent thrust faults at the southern end of the Maacama fault west of Napa Valley.

We suggest that the apparent termination of the GVF at Wooden Valley reflects transfer of at least some dextral slip westward across the contractional structures in the Howell Mountains. Based on geologic cross-sections and an age of 2.9 Ma for the upper Sonoma Volcanics (Fox, 1983), we estimate a minimum shortening of $6 \mathrm{~km}$ across the Conn Creek anticline and Foss Valley syncline, implying a long-term average NE-SW shortening rate of about $2 \mathrm{~mm} / \mathrm{yr}$ northwest of the GVF. Historical seismicity in the vicinity of the Howell Mountains (i.e., the M5.5 earthquake of 10/12/1891; Toppozada et al., 1981), folded late Quaternary (?) alluvium, and possible late Quaternary faulting documented by excavations for water supply facilities in eastern Napa Valley, suggest that these lineaments may be active tectonic features associated with folding.

$* * *$ 


\section{REFERENCES FOR NEHRP-FUNDED PALEOSEISMOLOGY WORK IN NORTHERN CALIFORNIA}

John N. Baldwin, William Lettis and Associates

1777 Bothelho Dr., Suite 262, Walnut Creek, CA 94596

Baldwin, J.N., Knudsen, K.L., Prentice, C.S., Lee, A., Gross, R., in review, Timing of a prehistoric earthquake and estimate of coseismic displacement of the penultimate earthquake on the northern San Andreas fault, Pt. Arena, California, submitted to Geological Society of America Bulletin, $31 \mathrm{p}$.

Prentice C.S., Crosby, C.J., Harding, D.J., Haugerud, R.A., Merritts, D.J., Koehler, R.D., and Baldwin, J.N., 2003, Northern California LIDAR data: A tool for mapping the San Andreas fault and Pleistocene Marine Terraces in heavily vegetated terrain, abs. American Geophysical Union 2003 Fall Meeting, San Francisco, December 8-12, 2003, EOS Supplement.

Green, A., Gross, R., Holliger, K., Horstmeyer, H., and Baldwin, J., 2003, Results of 3-D georadar surveying and trenching across the San Andreas fault near its northern landward limit, Tectonophysics 368, 7-23.

Knudsen, K.L., Witter, R.C., Garrison-Laney, C.E., Baldwin, J.N., Carver, G.A., 2002, Past earthquake-induced rapid subsidence along the northern San Andreas fault: A paleoseismological method for investigating strike-slip faults, in Bulletin Seismological Society of America, v.. 92, no. 7, p. 2612-2636.

Borchardt, G. and Baldwin, J.N., 2001, Late Holocene behavior and seismogenic potential of the Concord-Green Valley fault system in Contra Costa and Solano Counties, CA: in Ferriz, H. (ed.), Engineering Geologic Practice in Northern California: Association of Engineering Geologists special volume.

Prentice, C. S., Langridge, R., Baldwin, J.N., Dawson, T., Merritts, D.J., and Crosby, C.J., 2001, Paleoseismic and Quaternary tectonic studies of the San Andreas fault between Point Arena and Fort Ross, northern California, USA, abs., International Conference on Paleoseismology, conference held in New Zealand.

Simpson, G.D., Baldwin, J.N., Kelson, K.I., Lettis, W.R., 1999, Late Holocene slip rate and earthquake history for the northern Calaveras fault at Welch Creek, eastern San Francisco Bay area, California: Bulletin of Seismological Society of America, v. 89, p. 1250-1263.

Unruh, J.R., Sawyer, T.L., and Baldwin, J.N., 1999, Transpressional tectonics of the eastern Coast Ranges in central California abs.: Geological Society of America Abstracts with Programs, Cordilleran Section, v. 31, A-103.

Baldwin, J.N., and Unruh, J.R., 1997, Neotectonic lineaments and Quaternary folds in the Howell Mountains, eastern Napa County, California: Restraining stepover at the northern termination of the Green Valley Fault? [abs.]: Annual American Geophysical Union, v. 78, p. F632.

Kelson, K.I., Baldwin, J.N., and Randolph, C.E., 1997, Geologic slip rate along the southern Calaveras fault at San Ysidro Creek near Gilroy, California, abs.: Annual American Geophysical Union, v. 78, p. F439.

Knudsen, K.L., Garrison, C.E., Baldwin, J.N., Carver, G.A., Lettis, W.R., 1997, Evidence for earthquake-induced, rapid subsidence preserved in estuarine sediment along the North Coast segment of the San Andreas fault, abs.: Geological Society of America Abstracts with Programs, Annual Meeting, v. 29, A-206.

Simpson, G.D., Baldwin, J.N., Kelson, K.I., Lettis, W.R., 1997, Late Holocene slip rate and earthquake history of the northern Calaveras fault at Welch Creek, eastern San Francisco Bay area, California abs.: Annual American Geophysical Union, v. 78, p. F439.

$* * *$ 


\section{U. S. GEOLOGICAL SURVEY CONTRIBUTIONS TO PROJECT IMPACT IN OAKLAND}

John Boatwright, USGS/Project Impact Liaison

USGS, Menlo Park, CA 94025

In January 1998, the City of Oakland was named by FEMA as one of seven pilot Project Impact communities. Project Impact: Building a Disaster Resistant Community, was a national initiative that aimed to change the way America deals with disasters by encouraging communities to assess their vulnerabilities to hazards and implement strategies to limit damage before disasters occurred. The Western Region Earthquake Hazards Team, collaborated with the Oakland Office of Emergency Services, the California Geological Survey, and EQE International to develop hazard assessments from earthquake ground shaking, liquefaction, and landslides.

The first USGS effort to produce results in Oakland was John Evans' deployment of seven prototype strong motion instruments within the city. These TREMOR instruments record strong ground motion and send the peak accelerations, peak velocities, and response spectral amplitudes at three periods back to Menlo Park in a data packet that arrives within $90 \mathrm{~s}$ of the trigger time, to be incorporated into ShakeMap. In a remarkable shakedown, all seven instruments recorded and transmitted data for the M 4.7 Bolinas earthquake that occurred on September 17, 1999 (see Evans et al., 2004). The array was expanded to eleven instruments in 2000 and has contributed data to all of the ShakeMaps of local events.

Russ Graymer's publication of the USGS digital geologic maps, that is, the nine 7.5" quads that encompass the City of Oakland, was similarly rapid. The scanning, checking, and publication of these geologic maps was greatly expedited to allow their incorporation into all the aspects of the hazards calculations that require a digital geologic base.

These digital maps form the base for mapping two different landslide hazards. In 2001, Scott Miles and David Keefer published maps of the potential landslides triggered by an M 7.1 earthquake that ruptured both the northern and southern segments of the Hayward fault. In this research, they used a Newmark analysis to model the landslides that might be triggered by strong ground shaking. In 2001, Dick Pike published a map of the landslide susceptibility of the Oakland hills, that used the mapped landslide deposits, geology, and slopes to predict geologic landslide hazard.

The choice of Oakland as a Project Impact community made it a natural study area for the Cone Penetrometer Truck (CPT). The CPT measures tip resistance, sleeve resistance, and shear wave velocity as the penetrometer is pushed vertically through shallow sediments $(\leq 30 \mathrm{~m})$. Some 210 CPT holes were punched in various geologic units in Oakland and Alameda in two years of work. Holzer et al. (2002) used this CPT data to construct a 3D geologic map of the near-surface sedimentary units, and to map the liquefaction hazard from a M 7.1 earthquake on the nearby Hayward fault.

Finally, this detailed 3D map of the near-surface sediments was the critical element necessary for the map of ground motion in Oakland expected from a M 7.1 earthquake on the Hayward fault produced by Hand et al. (2004). These authors used a Monte Carlo simulation of ground motion in a variable $1 \mathrm{D}$ velocity structure. The velocity structure had three components: a set of welldetermined near-surface Holocene sedimentary layers, a set of poorly determined Pleistocene and Tertiary sedimentary layers, and a Franciscan basement. They used an equivalent linear 
approximation of non-linear soil behavior. They found that despite the extensive mapping and consequent resolution of the near-surface $S$-wave velocity and thickness performed by Holzer et al. (2002), the prediction of ground motion in the sediments was most sensitive to Vs30.

\section{REFERENCES}

Evans, J. R., and Hamstra, R. H. Jr., Spudich, P., Kündig, C., Camina, P., and Rogers, J.A., 2004, TREMOR: A wireless, MEMS accelerograph for dense arrays, Earthquake Spectra, (submitted).

R.W. Graymer, 2001, Miscellaneous Field Studies Map MF-342 Geologic Map and Map Database of the Oakland Metropolitan Area, Alameda, Contra Costa, and San Francisco Counties, California, http://geopubs.wr.usgs.gov/map-mf/mf2342,

Hand, E.K., Boatwright, J., and Silva, W.J., 2004, A sensitivity analysis of ground motion in Oakland for a Hayward fault earthquake, Bull. Seism. Soc. Am., (submitted).

Holzer, T.L.,, Bennett, M.J., Noce, T.E., Padovani, A.C., and Tinsley, J.C., III, 2002, Liquefaction hazard and shaking amplification maps of Alameda, Berkeley, Emeryville, Oakland, and Piedmont: a digitial database. US Geological Survey Open-file Report 02-296. http:// geopubs.usgs.wr.gov/open_file/of02-296.

Miles, S.B., and Keefer, D.K., 2001, Seismic landslide hazard for the cities of Oakland and Piedmont, California: USGS MF Map 2379, scale 1:24,000 and 14 pp. text, http://geopubs. wr.usgs.gov/map-mf/mf2379.

Miles, S.B., and Keefer, D.K., 2001, Seismic landslide hazard for the city of Berkeley, California: USGS MF Map 2378, scale 1:24,000 and 13 pp. text, http://geopubs.wr.usgs.gov map-mf/mf2378.

Pike, R.J., Graymer, R.W., Roberts, S., Kalman, N.B., and Sobierszczyk, S., 2001, Map and map database of susceptibility to slope failure by sliding and earthflow in the Oakland area, California: USGS MF Map 2385, 37 pp., http://geopubs.wr.usgs.gov/map-mf/mf2385). 


\section{THE NEXT GENERATION OF ATTENUATION RELATIONS (NGA) PROJECT-- A Collaborative Project with the Pacific Earthquake Engineering Research Center, the US Geological Survey, the California Geological Survey, and the Southern California Earthquake Center.}

Jack Boatwright, USGS/NGA Liaison

USGS, Menlo Park, CA 94025

The objective of the Next Generation of Attenuation (NGA) Project is to develop new and consistent ground motion attenuation models for earthquakes in the western United States. By expanding and standardizing in a database the existing strong motion data, creating earthquake descriptions or "metadata," and developing site characterizations, the NGA project hopes to effect a consensus of attenuation relations for western U. S. earthquakes. Five modelers or "developers" will each work on revising their attenuation relationships in a consistent manner to best reproduce the available observations.

The NGA research effort is comprised of five critical preparation tasks, four working groups, and the development task itself. These 10 elements are depicted in Figure 1 along with two subsequent development and modeling tasks. Preparation Task 1, expanding and standardizing the strong motion database, and Task 4, determining the empirical and theoretical soil amplification factors, are fundamental for the success of the project. The different regressions must be run on equivalent sets of strong motion database with equivalent earthquake descriptions, and with a complete set of site characterizations.

USGS involvement in NGA is extensive. Dave Boore (USGS, Menlo Park) is one of the 5 attenuation modelers, and will upgrade the strong motion regressions that he and Bill Joyner pioneered in 1980 and revised in 1996 and 1997. Roger Borcherdt (USGS, Menlo Park) and Ned Field (USGS, Pasadena) are leading and serving on Working Group1, the site amplification working group. Mark Petersen (USGS, Golden) and Paul Spudich, Jack Boatwright, and Ruth Harris (all 3 at USGS, Menlo Park) are serving on Working Group 4, the ground motion model development working group. In addition, Paul Spudich has already contributed a significant theoretical recasting of source directivity for NGA. He is also providing the strong motion database with all the strong ground motion he had assembled for a DOE-funded regression of ground motion from extensional earthquakes. Jack Boatwright and Linda Seekins (USGS, Menlo Park) are analyzing ground motions from five $\mathrm{M} \sim 5$ events in southern California to establish effective "Green's functions" for propagation characteristics. With the help of Rufus Catchings, Mark Goldman, and Shane Detweiler, Jack Boatwright and Walter Mooney (all USGS, Menlo Park) are collating the velocity structures obtained from nine refraction lines shot in the Bay Area from 1980 to 2003 in order to test the sedimentary depths in the Brocher et al. (1996) 3D velocity model. Chris Stephens (USGS, Menlo Park) has reprocessed some sixty records for the strong motion database.

The NGA project is working toward a deadline of March, 2005. Because much of the work is effectively serial, that is, the strong motion database must be completed before the developers can run their regressions, the schedule is very tight. However, the broad objectives of the project and the collective emphasis of the work will ensure that this effort will be a critical advance for earthquake engineering. When the project is completed the new, standardized ground motion database will be made publicly available on the web. 


\section{Next Generation Attenuation (NGA) Models}

\section{Objective: Develop New and Comparable Ground Motion Attenuation Models for WUS Crustal Earthquakes \\ Researchers: PEER-LL, USGS, CGS, \& SCEC}
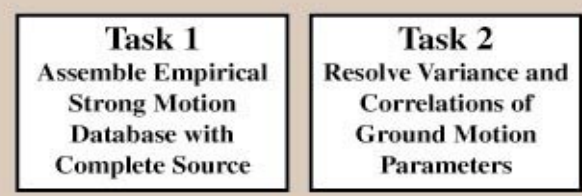

\begin{tabular}{|c|}
\hline Task 8 \\
Develop Engineering \\
Model for Fault Fling \\
\hline
\end{tabular}

Task 4

Build Empirical and

Theoretical Soil

Amplification Factors
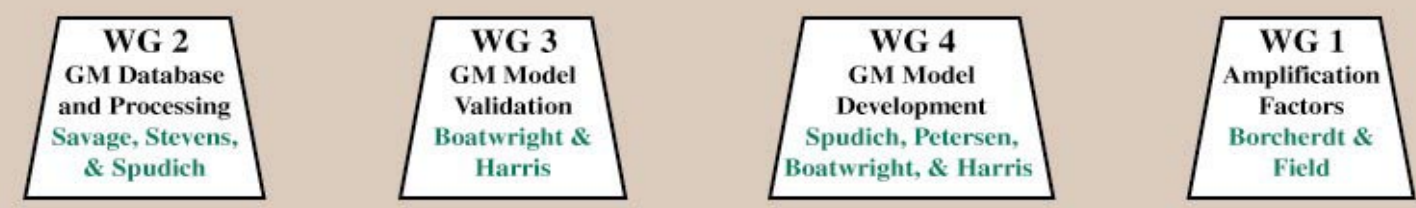

Task 6

Update Major Empirical Attenuation Models Abrahamson \& Silva, Boore, Campbell \& Bozorgnia, Chiou \& Youngs, Idriss
Task 7

Develop Hybrid Attenuation

Models using Empirical \& Simulated Data
Task 5

Develop Scenario Maps for 3-D Basin Effects in Los Angeles and the Bay Area

Figure 1. Structure of the Next Generation Attenuation Relations (NGA) Project showing Tasks and Working Groups. USGS participants are indicated in green.

$* * *$ 


\section{LATE HOLOCENE BEHAVIOR AND SEISMOGENIC POTENTIAL OF THE CONCORD-GREEN VALLEY FAULT SYSTEM IN CONTRA COSTA AND SOLANO COUNTIES, CALIFORNIA}

Glenn Borchardt and John N. Baldwin

William Lettis \& Associates, 1777 Bothelho Dr., Suite 262, Walnut Creek, CA 94593

The dextral strike-slip Concord-Green Valley fault (CGVF) system traverses the heavily populated I-680 and I-80 corridor in the eastern San Francisco Bay area. Recent paleoseismic studies at Galindo Creek and Lopes Ranch provide new insight into the seismic behavior of this fault system. The 16-to 24-km-long Concord fault appears to have a geologic slip rate $(3.4 \pm 0.3$ $\mathrm{mm} / \mathrm{yr}$ ) similar to the average "long-term" (18-year record) creep rate for the fault (3-4 mm/yr). Based on the presence of ductile deformation at Galindo Creek, it appears likely that part of the Concord fault behaves primarily aseismically and seldom has catastrophic ground rupture associated with major earthquakes. Trench exposures on the northern part of the Concord fault and on the southern part of the Green Valley fault (GVF), however, suggest multiple episodes of surface faulting. Based on the occurrence of a M5.4 earthquake on the central part of the Concord fault in 1955, it appears that the fault is at least partly locked at depth. It is unknown if $\leq$ M5.5 earthquakes are typical of the southern part of the CGVF and large earthquakes are typical of the northern part of the CGVF. Paleoseismic studies at Lopes Ranch on the GVF suggest that multiple surface-rupturing events have occurred within the last 2,700 years. The preliminary minimum slip rate at Lopes Ranch is 3.8 to $4.8 \mathrm{~mm} / \mathrm{yr}$ (over the last 300 years) - similar to the 14-year average creep rate of $4.9 \mathrm{~mm} / \mathrm{yr}$. The CGVF appears not to have produced an earthquake greater than M5.4 since 1776 when the written record began in the Bay area.

$* * *$ 


\title{
VISCOELASTIC WAVE PROPAGATION IN LAYERED SOIL DEPOSITS: A THEORETICAL MODEL FOR SITE COEFFICIENTS IN BUILDING CODES
}

\author{
Roger D. Borcherdt \\ United States Geological Survey, Menlo Park, CA 94025
}

Theoretical solutions for wave propagation in layered anelastic media provide the theoretical basis for seismic wave propagation in layered soil and rock deposits. These exact theoretical solutions predict that physical characteristics of two and three dimensional wave fields in layered anelastic media are distinct from those predicted by elastic models or one dimensional anelastic models. They predict that the velocity, damping, particle motion, direction of energy flow, kinetic energy, potential energy and energy flux for anelastic waves vary with angle of incidence. These variations are most significant for anelastic waves in soils with large amounts of damping or for anelastic waves incident at the edge of a basin or near critical refraction angles.

Application of these results to the problem of site response characterization for purposes of building code provisions shows that the theoretical solution for a viscoelastic soil layer over rock provides an exact theoretical model for site coefficients, $\mathrm{Fa}$ and $\mathrm{Fv}$, in current building code provisions (e.g. NEHRP, IBC, ICC, and ASCE 7 provisions). Parametric analyses conducted from the theoretical solutions with Mathematica shows that average site response characteristics for vertically incident Type-II $S$ waves are in good agreement with those specified in current code provisions as a function of site class (shear velocity) and base acceleration. With the exception of inhomogeneous wave fields incident at shallow angles of incidence on basin margins, the parametric analyses suggest that $\mathrm{Fa}$ and $\mathrm{Fv}$ in code provisions conservatively account for the average short- and long-period characteristics of the dynamic response of an anelastic soil layer.

$* * *$ 


\section{DATA SOURCES FOR THE USGS THREE-DIMENSIONAL VELOCITY MODEL FOR THE SAN FRANCISCO BAY AREA, CALIFORNIA}

Thomas M. Brocher, Robert C. Jachens, and Carl M. Wentworth

U.S. Geological Survey, 345 Middlefield Rd., Menlo Park, CA 94205

We summarize data sources used to generate the USGS three-dimensional shear- and compressional-wave velocity model for the greater San Francisco Bay area (Brocher et al., 1997). The model extends north to south from San Pablo Bay to Monterey Bay, and west to east from the San Gregorio fault near the coast to the center of the Diablo Range. Our goal in developing this USGS model was to produce the most geologically accurate model possible for the calculation of strong ground motions produced by anticipated earthquakes in the Bay area (Hartzell et al., 1998). The model has been compiled in two steps: (1) the assembly of a three-dimensional model of principal faults and stratigraphic boundaries, and then (2) the assignment of seismic properties to the volumes delineated by these discrete surfaces. The model boundaries have been compiled from a variety of geological and geophysical data and/or models, each having its own intrinsic resolution and accuracy. These boundaries include: a detailed GIS-based map of the velocities at the surface based on geological mapping of the physical properties of surficial geological units (Fumal, 1978; Helley and Graymer, 1997a, b; Wentworth, 1997; Wentworth et al., 1997; Wagner et al., 2002), the base of Plio-Quaternary deposits, the base of Cenozoic sedimentary basin fill (Jachens et al., 1997), and the tops of the reflective lower crust and upper mantle (Brocher et al., 1999). These boundaries are offset by the San Andreas, Zayante, Hayward, Calaveras, and Pilarcitos faults, which are assigned dips that vary along strike. The model extends from the surface, currently assumed to be at sealevel, to the base of the crust. The middle and lower crust of the model is virtually identical to that used by Stidham et al. (1999).

Key elements of the model important to strong ground motions include a new map of shear- and compressional-wave velocities at the surface based on a digital surficial geologic materials map, refined estimates for the geometry and thicknesses of several Cenozoic sedimentary basins, a strong contrast in P- and S-wave velocities at top of the middle crust ( $16 \mathrm{~km}$ depth) leading to strong midcrustal P- and S-wave reflections at ranges of 40-60 km, and a thin $(22-26 \mathrm{~km})$ crust leading to large-amplitude PmP and SmS reflections at ranges of 80-100 km. An important uncertainty of the model includes the absence of borehole or seismic control on the depth of the thickest Cenozoic basins, and of the shear-wave velocities of the basin filling sedimentary rocks.

The very abbreviated bibliography included below provides an introduction into the sources of available information on the crustal structure in the SF Bay Area. Boore (2003) summarized Pand S-wave velocities logged by the USGS in shallow (30-m) boreholes. Information on wells logs available from oil industry boreholes in northern California is given by Brocher et al. (1997), Tiballi et al. (1998), Brabb et al. (2001), and Brocher (in prep.). A summary of crustal refraction experiments conducted in northern California is provided by Brocher et al. (1999) and Brocher (2003a,b). Holbrook et al. (1996) present results from the Bay Area Seismic Imaging experiment (BASIX) and Hole et al. (2000) inverted first arrival times from earthquakes and BASIX shots for the most recent 3-D tomography study of the greater Bay Area. Williams et al. (1999) present a Data Report for unpublished seismic refraction profiles in the Livermore Valley and the Santa Cruz mountains.

Many potential improvements to the 3-D model, dating to 1997, are now possible, and we highlight several of these. S- and P-wave velocity logs for several 300-m-deep wells in the Santa Clara valley (Wentworth et al., this volume), sampling mainly Quaternary units, should 
improve estimates of shear-wave velocities for these units. Recent results of seismic reflection and refraction profiling in Santa Clara valley (Williams et al., 2002; Catchings et al., 2003) permit improved delineation of Quaternary sedimentary deposits in the valley. Marine high-resolution seismic reflection studies in the San Francisco bay and offshore the Golden Gate (Parsons, 2002) provide useful images for several Cenozoic basins. Parsons et al. (2001) present a simple algorithm for incorporating gravity observations into seismic tomography inversions: application of this technique to the Bay Area may improve our understanding of the Cenozoic basin geometry. Finally, recent observations of wave propagation in the Bay Area can be used to test the 3-D model (Baise et al., 2003; Fletcher et al., 2003; Hartzell et al., 2003).

\section{SELECTED BIBLIOGRAPHY}

Baise, L.G., D.S. Dreger, and S.D. Glaser, 2003, the effect of shallow San Francisco Bay sediments on waveforms recorded during the Mw 4.6 Bolinas, California, earthquake, Bull. Seism. Soc. Am., 93, 465-479.

Boore, D.M., 2003, A compedium of P- and S-wave velocities for surface-to-borehole logging: Summary and reanalysis of previously published data and analysis of unpublished data, U.S. Geol. Surv. Open-File Rept. 03-191, 14 p. http://geopubs.wr.usgs.gov/open-file/of03-1911.

Brabb, E.E., C. Powell, II, and T.M. Brocher, 2001, Preliminary compilation of data for selected oil test wells in Northern California, U.S. Geol. Surv. Open-File Rept. 01-152, 310 pp. http:// geopubs.wr.usgs.gov/open-file/of01-1521.

Brocher, T.M., in prep., Borehole Constraints on the seismic velocity and density of Cenozoic sedimentary basins in the San Francisco Bay area, California, Bull. Seism. Soc. Am.

Brocher, T.M., 2003a, Detonation charge size versus coda magnitude relations in California and Nevada, Bull. Seism. Soc. Am., 93, 2089-2105.

Brocher, T.M., 2003b, Hypocentral accuracy of surficial detonations in northern California, Seism. Res. Lett., 74, 12-19.

Brocher, T.M., E.E. Brabb, R.D. Catchings, G.S. Fuis, T.E. Fumal, R.A. Jachens, A.S. Jayko, R.E. Kayen, R.J. McLaughlin, T. Parsons, M.J. Rymer, R.G. Stanley, C.M. Wentworth, 1997, A crustal-scale 3-D seismic velocity model for the San Francisco Bay area, California, Eos, Trans. AGU, Suppl., 78(46), F435-6.

Brocher, T.M., Ruebel, A.L., and Brabb, E.E., 1997, Compilation of 59 sonic and density logs from 51 oil test wells in the San Francisco Bay area, California, U.S. Geol. Surv. Open-File Rept. 97-687, 74 p.

Brocher, T.M., U.S. ten Brink, and T. Abramovitz, 1999, Synthesis of crustal seismic structure and implications for the concept of a slab gap beneath Coastal California, Intern. Geol. Rev., 41, 263-274.

Catchings, R.D., M.R. goldman, M.J. Rymer, C.E. Steedman, and G. Gandhok, 2003, Subsurface structure of the eastern Santa Clara Valley from downtown San Jose to the Calaveras fault, Eos Trans. AGU, Fall Meet. Suppl., 84(46), Abs. S21F-0392.

Fletcher, J.B., J. Boatwright, and A.G. Lindh, 2003, Wave propagation and site response in the Santa Clara valley, Bull. Seism. Soc. Am., 93, 480-500.

Fumal, T.E., 1978, Correlations between seismic wave velocities and physical properties of nearsurface geologic materials in the southern San Francisco Bay region, California, U.S. Geol. Surv. Open-File Rept. 78-1067, 114 p. 
Hartzell, S., R. Jachens, T. Brocher, and A. Frankel, 1998, Imaging and ground motion in urban sedimentary basins: The Santa Clara and San Bernadino Valleys, U.S. Geol. Surv. Open-File Rept. 98-244, 28 p.

Hartzell, S., D. Carver, R.A. Williams, S. Harmsen, and A. Zerva, 2003, Site response, shallow shear-wave velocity, and wave propagation at the San Jose, California, dense seismic array, Bull. Seism. Soc. Am., 93, 443-464.

Helley, E.J., and Graymer, R.W., 1997a, Quaternary geology of Alameda County, and parts of Contra Costa, Santa Clara, San Mateo, San Francisco, Stanislaus, and San Joaquin Counties, California: A digital database: U.S. Geol. Surv. Open-File Rept. 97-97.

Helley, E.J., and Graymer, R.W., 1997b, Quaternary geology of Contra Costa County and surrounding parts of Alameda, Marin, Sonoma, Solano, Sacramento, and San Joaquin Counties, California, a digital database: U.S. Geol. Surv. Open-File Rept. 97-98.

Holbrook, W.S., T.M. Brocher, U.S. ten Brink, and J.A. Hole, 1996, Crustal structure of a transform plate boundary: San Francisco Bay and the central California continental margin, J. Geophy. Res., 101, 22,311-22,334.

Hole, J.A., T.M. Brocher, S.L. Klemperer, T. Parsons, H.M. Benz, and K.P. Furlong, 2000, Threedimensional seismic velocity structure of the San Francisco Bay area, J. Geophy. Res., 105, $13,859-13,874$.

Holzer, T.L., C.M. Wentworth, W.H. Bakun, J. Boatwright, T.M. Brocher, M. Celebi, W.L. Ellsworth, J.P.B. Fletcher, E.L. Geist, R. W. Graymer, R.E. Kayen, D. K. Keefer, D. H. Oppenheimer, W.U. Savage, D.P. Schwartz, and R. W. Simpson, 2002, Comments on potential geologic and seismic hazards affecting Mare Island, Solano County, California, USGS Open-File Rept. 02-425, http://geopubs.wr.usgs.gov/open-file/of02-425.

Jachens, R.C., Sikoro, R.F., Brabb, E.E., and others, 1997, The Basement Interface: San Francisco Bay Area, California, 3-D Seismic Velocity Model, Eos, Trans. AGU, Suppl., 78(46), F436.

Parsons, T., 2002, Crustal Structure of the coastal and marine San Francisco Bay region, California, editor, U.S. Geol. Surv. Prof. Pap. 1658, 145 p.

Parsons, T., R.J. Blakely, and T.M. Brocher, 2001, A simple algorithm for sequentially incorporating gravity observations in seismic traveltime tomography, Intern. Geol. Rev., 43, 1073-1086.

Stidham, C., Dreger, D., Antolik, M., Larsen, S., and Romanowicz, B., 1999, Three-dimensional structure influences on the strong motion wavefield of the 1989 Loma Prieta earthquake. Bull. Seism. Soc. Am., 89, 1184-1202

Tiballi, C.A., and Brocher, T.M., 1998, Compilation of 71 additional sonic and density logs from 59 oil test wells in the San Francisco Bay area, California, U.S. Geol. Surv. Open-File Rept. 98-615, $131 \mathrm{pp}$.

Wagner, D.L., Greene, H.G., Saucedo, G.J., and Pridmore, C.L., 2002, Geologic map of the Monterey 30'x60' quadrangle and adjacent areas, California: A digital database: Calif. Geol. Surv. CD2002-04.

Wentworth, C.M., 1993, General distribution of geologic materials in the southern San Francisco Bay Region, California: A digital database, U.S. Geol. Surv. Open-File Rept. 93-693.

Wentworth, C.M., 1997, General distribution of geologic materials in the San Francisco Bay region, California: A Digital Map Database: U.S. Geol. Surv. Open-File Rept. 97-744. 
Wentworth, C.M., Fumal, T.E., Brocher, T.M., and Brabb, E.E., 1997, The areal distribution of geologic materials and their seismic velocities, San Francisco Bay area, California, 1997, Eos, Trans. AGU, Suppl., 78(46), F436.

Wentworth, C.M., R.C. Jachens, S.E. Graham, R.W. Graymer, R.T. Hanson, E.A. Mankinen, J.C. Tinsley, and R.A. Williams, 2004, Structure and stratigraphy of the Santa Clara valley, this volume.

Williams, A.J., T.M. Brocher, W.D. Mooney, and A. Boken, 1999, Data report for seismic refraction surveys conducted from 1980 to 1982 in the Livermore Valley and the Santa Cruz Mountains, California, U.S. Geol. Surv. Open-File Rept. 99-146, 78 pp. http://geopubs. wr.usgs.gov/open-file/of99-146.

Williams, R.A., Stephenson, W.J., Wentworth, C.M., Odum, J.K., Hanson, R.T., and R.C. Jachens, 2002, Definition of the Silver Creek fault and Evergreen Basin sediments from seismic reflection data, San Jose, California: Eos Trans. AGU, Fall Meet. Suppl., 83(47), p. F1313.

$* * *$ 


\section{QUATERNARY INVESTIGATIONS TO EVALUATE SEISMIC SOURCE CHARACTERISTICS OF THE FRONTAL THRUST BELT, PALO ALTO REGION, CALIFORNIA: COLLABORATIVE RESEARCH DESERT RESEARCH INSTITUTE AND GEOMATRIX CONSULTANT}

Tom Bullard ${ }^{1}$, Kathryn Hanson ${ }^{2}$, Hans Abramson ${ }^{2}$, and John Wesling ${ }^{2}$

${ }^{1}$ Desert Research Institute, 2215 Raggio Parkway, Reno, NV 89512 Tom.Bullard@DRI.edu

${ }^{2}$ Geomatrix Consultants, Inc., 2101 Webster St., 12th Floor, Oakland, CA, 94612

KHanson@Geomatrix.com

Active blind and emergent faults that occur in a deformation zone adjacent to and east of the San Andreas Fault (the Frontal thrust fault system; Fig. 1) pose a seismic hazard to communities and infrastructure in the Palo Alto and adjoining regions of the San Francisco Peninsula. Tectonic activity expressed in the geomorphology of this region led to geomorphic analysis that helped target areas for detailed mapping of Quaternary deposits and deformed surfaces. Resulting information was used to evaluate the location and activity of individual faults and the expected style of deformation that might occur in future earthquakes. During our previous studies in the region (Angell et al., 1997), a model of the kinematics and geometry of faulting was developed based on preliminary Quaternary investigations combined with analysis of bedrock structure and construction of a retrodeformable cross section. The 1997 study showed that the structures in this area were active during the latest Pleistocene and possibly the Holocene. Preliminary age estimates and vertical separations of the terraces suggested uplift rates of $0.15 \mathrm{~m} / \mathrm{kyr}$ for the Hermit fault, 0.15 to $0.2 \mathrm{~m} / \mathrm{kyr}$ for the Pulgas fault, and 0.4 to $0.6 \mathrm{~m} / \mathrm{kyr}$ for the Stanford fault zone. Our most recent study focuses on the latest Pleistocene and Holocene terraces that cross the Pulgas fault and Stanford fault zone along San Francisquito Creek (Hanson et al., 2001). This study incorporates available radiocarbon analyses, detailed topographic survey data, archaeological information, and geomorphic analysis. Geomorphic expression of deformation across the active structures includes prominent topographic relief aligned above growing folds, warped geomorphic surfaces, stream profile inflections, and changes in stream pattern. Terrace mapping refinements in the vicinity of the Stanford Golf Course (Fig. 2) show that latest Pleistocene terraces are gently folded across the Stanford fault zone but do not appear to be displaced across the Pulgas fault as previously thought (Angell et al., 1997). More detailed measurement of the vertical deformation of three terraces (Qt3b, Qt3c, and Qt3c $\mathrm{L}_{\mathrm{L}}$ ) derived from total station survey data (Fig. 3) and age estimates for the terraces (based on correlation to the terrace at the previously dated Stanford Man II site) indicate that the uplift rate across the Stanford fault zone is approximately 0.6 to $0.7 \mathrm{~mm} / \mathrm{yr}$.

\section{REFERENCES}

Angell, M.A., Hanson, K.L., and Crampton, T., 1997, Characterization of Quaternary contractional deformation adjacent to the San Andreas fault, Palo Alto, California: Final Report submitted to the U.S. Geological Survey, National Earthquake Hazards Reduction Program, Award NO. 1434-95-G-2586.

Hanson, K.L., Wesling, J.R., Angell, M.M., and Bullard, T.F., 2001, Quaternary investigations to evaluate seismic source characteristics of the Frontal Thrust Belt, Palo Alto region, California: status report of ongoing morphometric and geochronology studies, [abs \& poster]: Seismological Research Letters, v. 72, p. 246-247.

Bullard, T.F., Hanson, K.L., and Abramson, H., 2004, Quaternary investigations to evaluate seismic source characteristics of the Frontal Thrust Belt, Palo Alto region, California: collaborative research, Desert Research Institute and Geomatrix Consultants: Final Report submitted to the U.S. Geological Survey, National Earthquake Hazards Reduction Program, Award No. 01HQGR0015 (Desert Research Institute) and 01HQGR0016 (Geomatrix Consultants). 

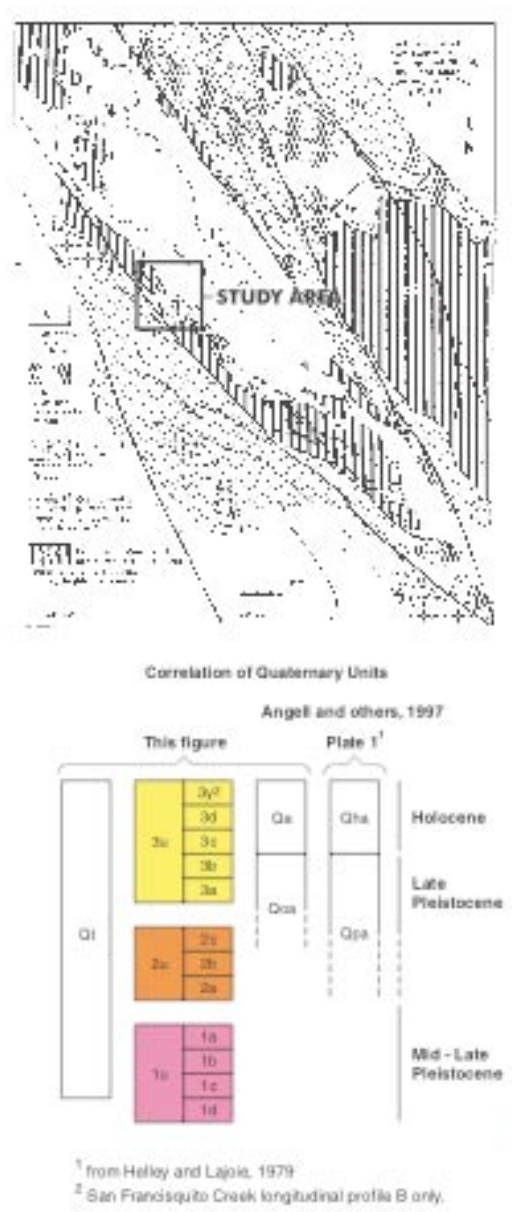

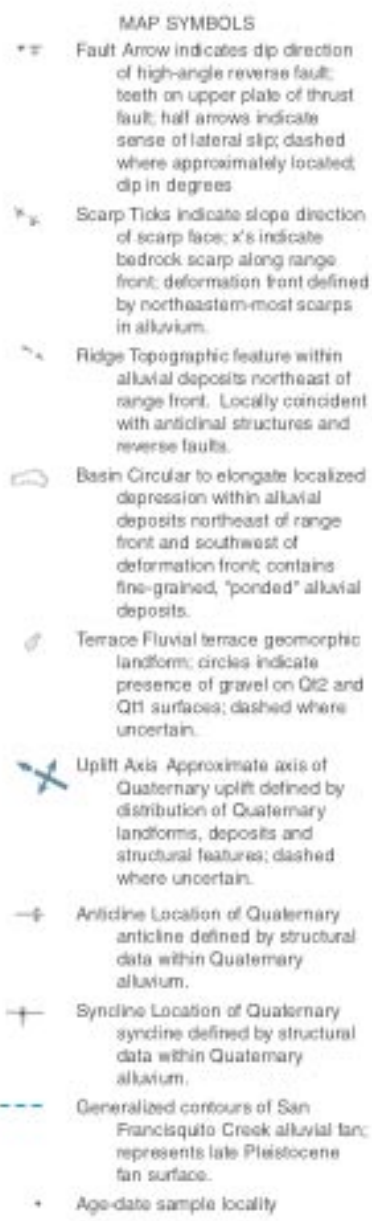

A9e duse smpla bocality
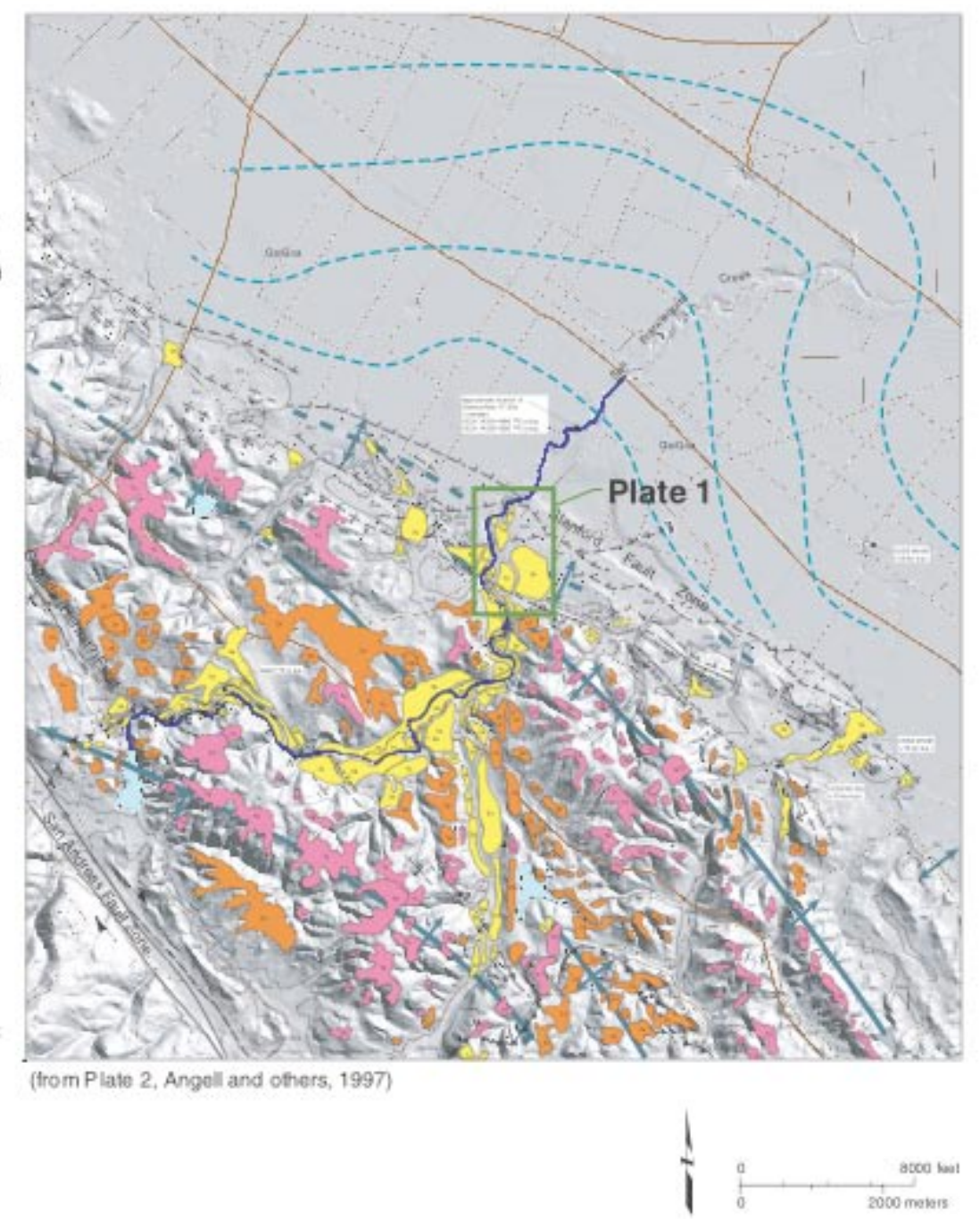


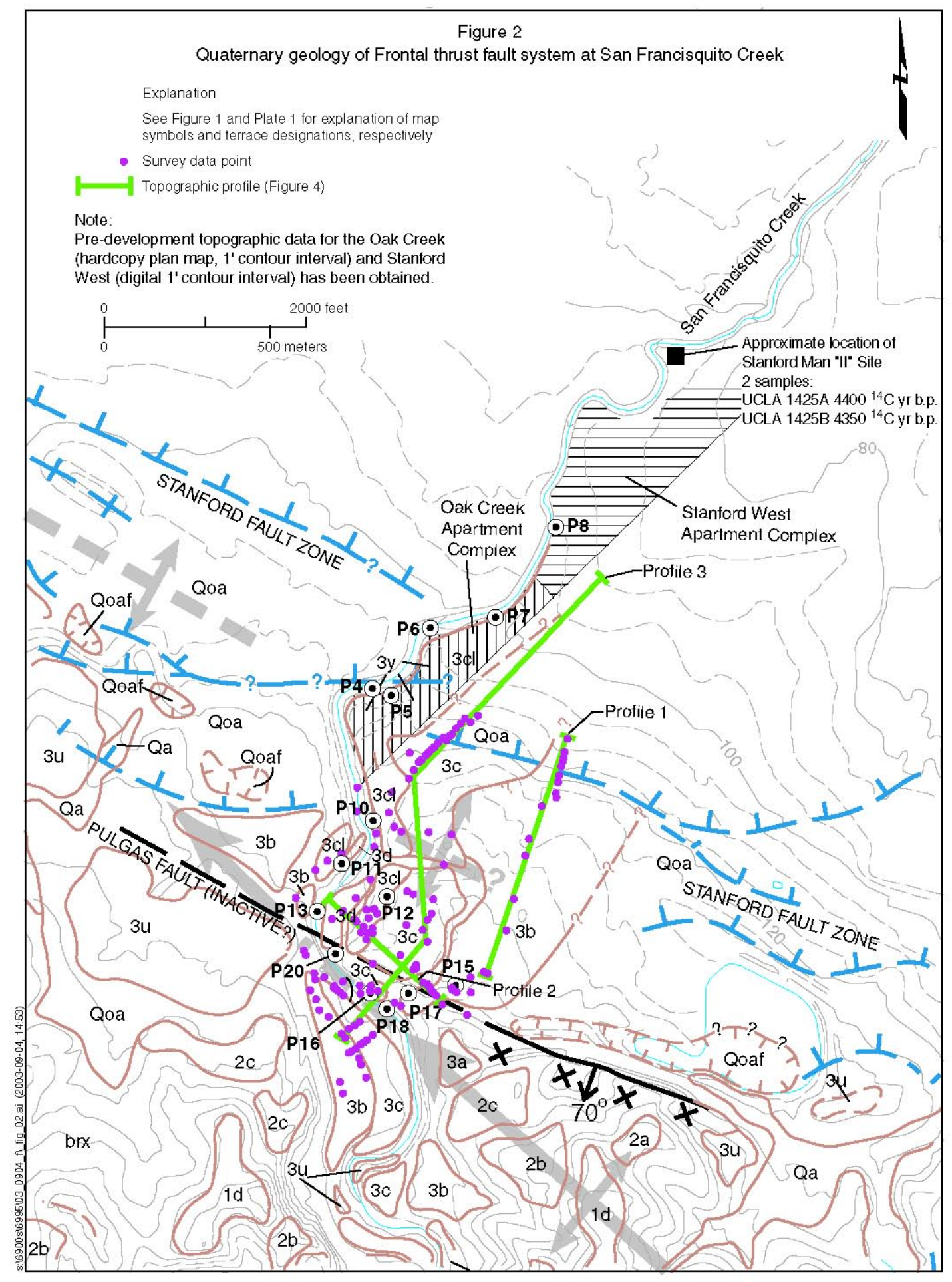



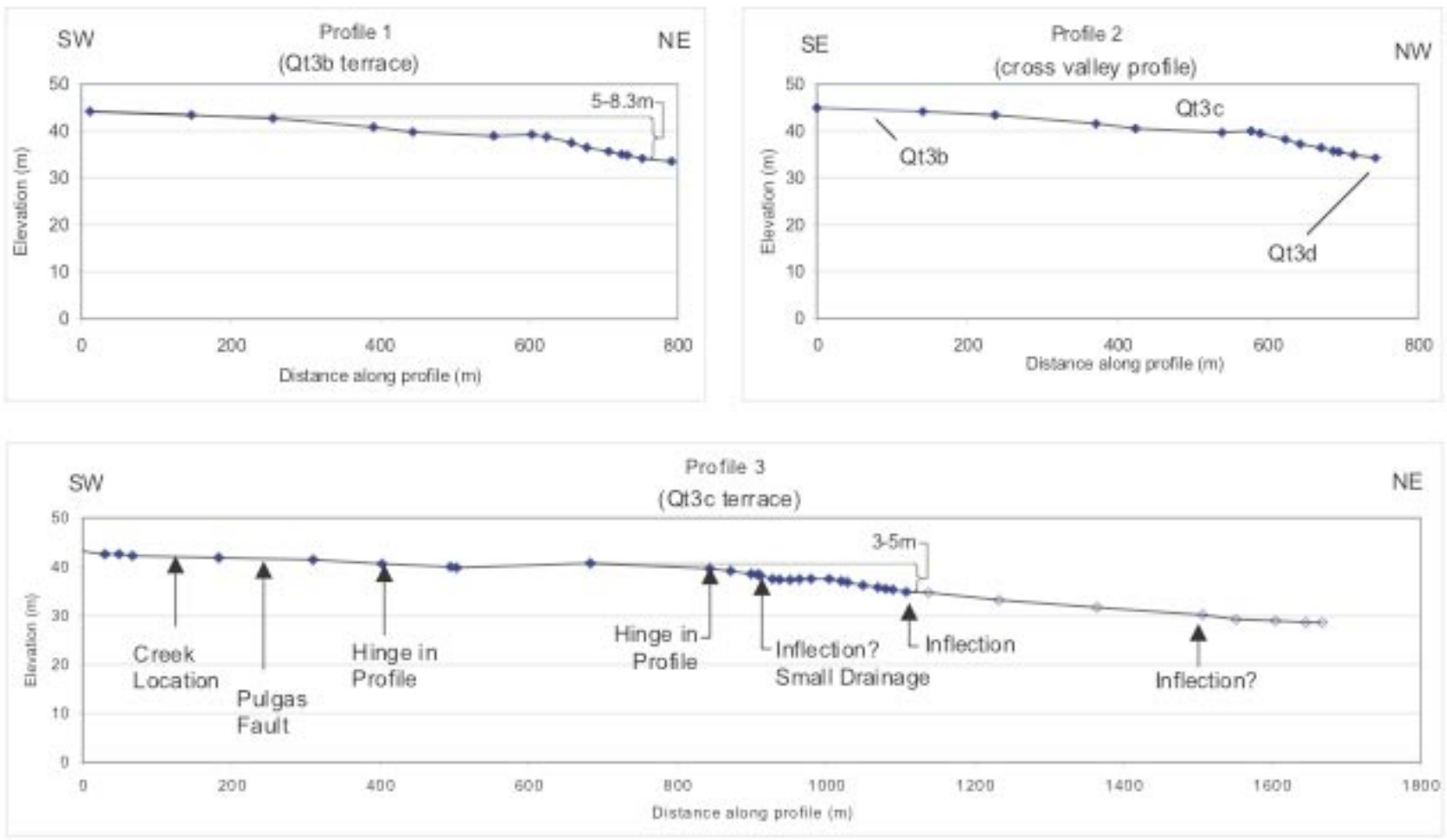

- Measurnd devation (Total Staton Survey)

Notes

Elevason from U.S.G.S Palo Alto 7.5' topographic

quadrangle (corrocted to conird banch mark), and survey

1) Survey elevafons are registered to "Sherwood" benchmark; NGS Benchmax

B151, elovaton 144.67 (NAD 29)

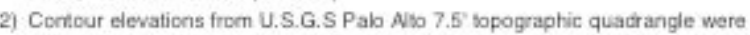

adjusted upuard 122 meters (4 feet) to match survay done tor this study and

survey from the Stanford West Apartment Complex.

Figure 3: Profiles of stream terraces along San Francisquito Creek. Profile locations are shown on Figure 2. 


\title{
CONTINUING THEODOLITE MEASUREMENTS OF SURFACE CREEP ON STRIKE- SLIP FAULTS IN THE SAN FRANCISCO BAY REGION
}

\author{
J. Caskey, K. Grove, F. McFarland, and M. Mascorro \\ Dept. of Geosciences, San Francisco State University, 1600 Holloway Ave., San Francisco, CA 94132 \\ caskey@sfsu.edu \\ J. Lienkaemper, U.S. Geological Survey, MS 977, Menlo Park, CA 94025 \\ jlienk@usgs.gov
}

The surface fault creep-monitoring program at San Francisco State University was created by Jon Galehouse in 1979, and has been funded from its beginning by the U.S. Geological Survey, National Earthquake Hazards Reduction Program. Since then, the project has produced an invaluable and unique data set (e.g., Galehouse, 2002; Galehouse and Lienkaemper, 2003) and has also provided reliable part-time research assistantships for more than two dozen students. We continue to monitor creep at about 30 measurement sites along active strike-slip faults in the San Francisco Bay region including several sites in northern California on the San Andreas and Maacama faults. Following Galehouse, we typically make theodolite measurements at each site about every two to three months, depending on whether or not the sites show a history of creep. On the Hayward fault, we also make annual measurements at 20 sites (e.g., Lienkaemper et al., 2001), in addition to our 11 regular measurement sites on the fault.

As observed by Galehouse and Lienkaemper (2003) the character of fault creep varies for different sites between gradual (steady-state) behavior and episodic (quasi steady-state) behavior whereby relatively rapid creep "events" lasting up to a few months are separated by slower periods of creep lasting several years. Other observations show that fault creep is sensitive to regional dynamicand static-stress changes induced by large seismic events such the 1989 Loma Prieta earthquake (Galehouse, 1990; Lienkaemper et al., 1997). For this reason, regional stress change models which can be created using Coulomb 2.5 (Toda and Stein, 2002) are considered essential tools for developing creep-monitoring strategies following future large earthquakes in the Bay Area. It is also widely recognized that creeping sections of faults are characterized by high rates of microseismicty. We are currently exploring the relations between temporal patterns of seismicity and details of creep behavior, particularly for sites that exhibit episodic or irregular creep. We are also in the process of building a website that will provide the public and scientific community with a description of the creep project and up-to-date creep measurement data.

\section{References}

Galehouse, J.S., 1990, Effect of the Loma Prieta earthquake on surface slip along the Calaveras fault in the Hollister area: Geophysical Research Letters, v. 17, p. 1219-1222.

Galehouse, J.S., 2002, Data from theodolite measurements of creep rates on San Francisco Bay region faults, California: 1979-2001: U.S. Geological Survey Open-File Report 02-225, 94 pp. (http:// geopubs.wr.usgs.gov/open-file/of02-225/).

Galehouse, J.S., and J.J. Lienkaemper, 2003, Inferences drawn from two decades of alinement array measurements of creep on faults in the San Francisco Bay region, Bulletin of the Seismological Society of America: v. 93, no. 6, p. 2415-2433.

Lienkaemper, J.J., Galehouse, J.S., and R.W. Simpson, 1997, Creep response of the Hayward fault to stress changes caused by the Loma Prieta earthquake: Science, v. 276, p. 2014-2016.

Lienkaemper, J.J., Galehouse, J.S., and Simpson, R.W., 2001, Long-term monitoring of creep rate along the Hayward fault and evidence for a lasting creep response to 1989 Loma Prieta earthquake: Geophysical Research Letters, v. 28, p. 2265-2268.

Toda, S., and R.S. Stein, 2002, Response of the San Andreas fault to the 1983 Coalinga-Nunez earthquakes: an application of interaction-based probabilities for Parkfield: Journal of Geophysical Research, v. 107, 10.1029/2001JB000172. 
CONSTRAINED FORWARD MODELING FOR SUBSURFACE VELOCITY STRUCTURE

Evans, J. R. (1), Brocher, T. M. ${ }^{(1)}$, Catchings, R. D. ${ }^{(1)}$, Fletcher, J. B. ${ }^{(1)}$, Holzer, T. L. ${ }^{(1)}$, Lindh, A. G. ${ }^{(1)}$, Mooney, W. D. ${ }^{(1)}$, Parsons, T. ${ }^{(1)}$, Pollitz, F. ${ }^{(1)}$, Wentworth, C. M. ${ }^{(1)}$, Frankel, A. D. ${ }^{(2)}$, Hartzell, S. ${ }^{(2)}$, and Williams, R. A. ${ }^{(2)}$

${ }^{(1)}$ United States Geological Survey, Menlo Park, CA 94025 and ${ }^{(2)}$ United States Geological Survey, Golden, CO 80225

As a type example, we aim to model the Santa Clara Valley (SCV) subsurface consistent with all data, credibly to all. A major earthquake is expected within 30 years in this large urban area of critical infrastructure. A good model is essential to risk mitigation.

The data are extensive yet heterogeneous. A 3D geologic map is being built. Three passive seismic data sets from 1998-2004 vary in spacing, aperture, and duration. There are many water wells and eight purpose-drilled holes, extensive surface geologic mapping, detailed shallow reflection profiles, 100 cone penetrometer sites with S-wave logs, nearby long-range refraction profiles, detailed refraction/reflection lines across the whole, decades of local-event records, and good gravity and magnetic coverage. Poor ray distribution and the wish to include non-seismic data make tomographic methods inappropriate. We believe there is a solution requiring collegial critique and help: We think it possible to accommodate all data, parameters, and methods, including geology. Clearly, we need the full scale range from less than $10 \mathrm{~m}$ to more than 10 $\mathrm{km}$; surfaces and units must be explicit. A very general tool is required, that can handle a formal inverse or, as appropriate, a hand tugging at a fault surface: thus, a "rules-based" model rather than grid-based.

Rules-based systems like Gocad ${ }^{\mathrm{TM}}$ include the graphical tools and software "hooks" needed for manual work and computation, permitting "constrained forward modeling" (CFM): a mix of 3D geologic mapping, 3D forward modeling, and multi-parameter inversions. CFM presupposes rich data sets, major programming, agreement on software systems, equations relating properties (e.g., unit name, density, etc.), and willingness among researchers with different perspectives to work as a team. We propose a collaboration to create a CFM system around a rules-based package and a specific effort to maintain compatibility and collaboration with SCEC.

$* * *$ 


\section{TREMOR AND DENSE NETWORKS}

Evans, J. R. ${ }^{(1)}$, Hamstra, R. H. Jr. ${ }^{(2)}$, Spudich, P. ${ }^{(1)}$, Kündig, C. ${ }^{(3)}$, Camina, P. ${ }^{(3)}$, and Rogers, J. A. ${ }^{(4)}$ (1) USGS, Menlo Park, CA 94025, (2) Circuit Solutions, 6125 Prospect Rd., San Jose, CA 95129, (3) GeoSIG Ltd., Kanalstrasse 11, 8152 Glattbrugg, Switzerland, (4) DAQ Systems, 15044 Kelly Canyon Rd., Bozeman, MT 59715

The ability of a strong-motion network to resolve wavefields can be described on three axes: frequency, amplitude, and space. While the need for spatial resolution is apparent, for practical reasons the spatial axis has often been neglected. TREMOR is a MEMS-based accelerograph also using wireless Internet to minimize lifecycle costs. TREMOR instruments can economically augment traditional ones, residing between them to improve the spatial resolution of the array. The TREMOR instrument described here has dynamic range of $108 \mathrm{~dB}$ between $\pm 2 \mathrm{~g}$ (18 bits), or $114 \mathrm{~dB}$ between $\pm 4 \mathrm{~g}$ (19 bits). It is linear to $<<1 \%$ of full scale (FS), with a response function effectively shaped electronically, not by the sensor. We developed an economical, very low noise, accurate $(<<1 \% \mathrm{FS})$ temperature compensation method. Displacement is easily recovered to 10-cm accuracy at full bandwidth, and better with care. We deployed prototype instruments in Oakland, California, beginning in 1998, with 13 now at mean spacing of $\sim 3 \mathrm{~km}$ - one of the most densely instrumented urban centers in the United States. This array is among the quickest in returning [PGA, PGV, $S_{a}$ ] vectors to ShakeMap, 75 to $100 \mathrm{~s}$. Some 12 events have been recorded. These technologies have been transferred to the private sector and are being introduced in conjunction with a recorder designed by the Canadian Geological Survey in both the TREMOR (18-bit); a 12-bit version is already on sale for about $\$ 500$ and could be operated by volunteers. Both are fully Internet ready and offer the opportunity for a three-layer array approaching 1-km spacing, as suggested schematically in the figure.

\section{A Nested Array Example}

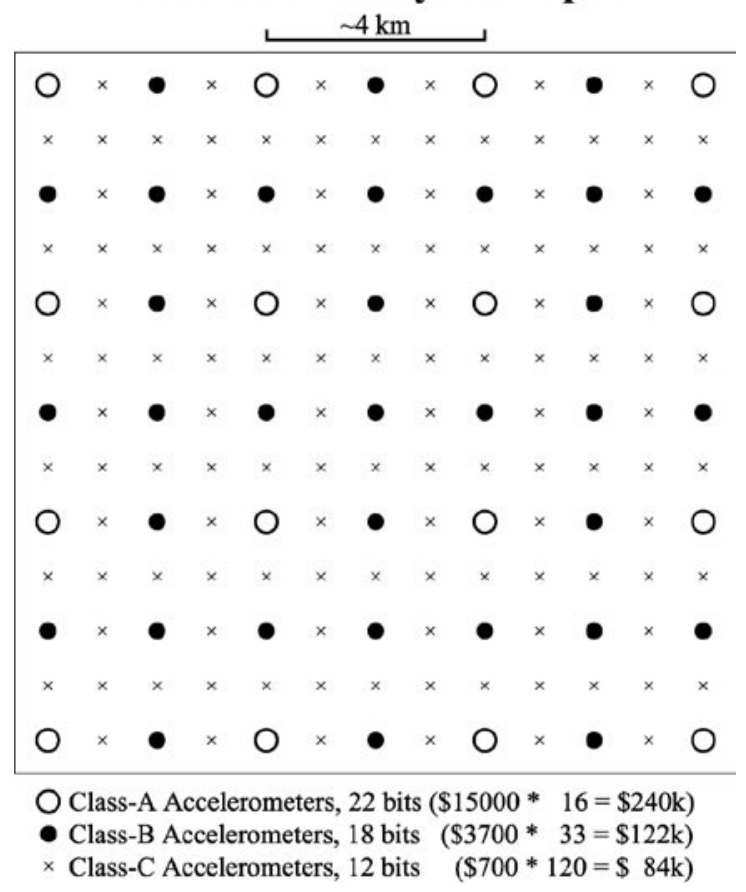

Figure 1. A "nested" array of "Class A", "B” (TREMOR), and "C" (\$700) instruments combined to provide amplitude, frequency, and spatial resolution. 


\section{COMMUNITY TOOLS FOR SEISMIC HAZARD ANALYSIS}

Edward (Ned) Field

United States Geological Survey, 525 S Wilson Ave., Pasadena CA 91106 (field@usgs.gov)

OpenSHA (http://www.OpenSHA.org) is an object-oriented, open-source, and web-based "community modeling environment" for seismic-hazard analysis (SHA). A primary goal has been to enable any arbitrarily sophisticated (e.g., physics-based) model to "plug in" for analysis without having to change what is being plugged into (without rewriting existing code) and to accommodate the rapidly evolving needs of the engineering community (e.g., new intensitymeasure types or vectors thereof). Another goal has been to enable the models, as well as the various data repositories upon which they depend, to be geographically distributed and run-time accessible via the Internet. Building such a community-modeling environment has raised several issues related to computational speed, ease of use, error prevention, and repeatability of results in an environment where the models and data are continually being updated. The Information Technology Research collaboration of the Southern California Earthquake Center http://www. SCEC.org/cme) is helping us resolve some of these issues. To date we've developed OpenSHA applications for computing hazard curves, hazard spectra, hazard maps, and scenario ShakeMaps.

Of particular interest is the implementation of the WGCEP-2002 earthquake-rupture forecast for the Bay Area. We have established runtime access to the WGCEP-2002 Fortran code, enabling fully time-dependent hazard calculations for a user defined time period, attenuation relationship, and intensity measure type (e.g., PGA, PGV, SA, ...). We have also honored the working group's extensive logic tree construction, where a separate hazard curve is computed for each branch. Finally, scenario ShakeMaps can also be computed for any of the ruptures defined by WGCEP2002, and for a user specified attenuation relationship and intensity-measure type. To view an example of the influence of directivity on ShakeMap predicted ground motions for a combined North Hayward-Rodgers Creek M=7.4 rupture, go the the OpenSHA web site and click on "Accomplishments", and see Figure 3.

$* * *$ 


\title{
SAN JOSE DENSE SEISMIC ARRAY: FINDINGS TO DATE AND FUTURE PLANS
}

\author{
A. D. Frankel, D. Carver, S. Hartzell, S. Harmsen, and R. Williams \\ U.S. Geological Survey, MS 966, Box 25046, DFC, Denver, CO 80225
}

Our goal is to make deterministic and probabilistic seismic hazard maps for the Santa Clara Valley area that include 3D sedimentary basin effects, shallow site response, rupture directivity, and time dependence. The San Jose Dense Seismic Array provides key information on basin effects and site response for this hazard mapping effort. This areal array consists of 45 accelerometers with a spacing of about $1 \mathrm{~km}$ deployed across the Evergreen sedimentary basin and currently extending west through downtown San Jose. The array was originally funded by the Pacific Gas and Electric Company. The array has recorded about 40 earthquakes to date on 30 or more stations, ranging from local earthquakes with magnitudes 2-3 to regional events such as the Hector Mine earthquake. We find that ground motions are amplified by about a factor of two along the western edge of the Evergreen basin, relative to a reference rock site, over a wide range of frequencies $(0.13-8 \mathrm{~Hz})$, for local and regional earthquakes. Waveforms of regional events show large basin surface waves traveling across the array. In some cases, these basin surface waves propagate from a direction about 70 degrees from that to the source. This indicates that these basin surface waves are scattered from the edges of the Santa Clara Valley. We are using the data from the array to test the 3D velocity model originally developed by Brocher et al. (1997) and currently being updated by R. Jachens. Our 3D simulations qualitatively reproduce the refracted surface waves and amplification pattern that are observed by the array. The mechanism for the amplification over the west edge of the Evergreen Basin is not clear; it is likely a combination of energy concentration by the shallowing of the basin, focusing by basin structure, $\mathrm{S}$-wave to surface wave conversion, and shallow site response. We plan to move much of the array over the Cupertino basin to study its effects on ground motions. The validated 3D velocity model will be used in simulations of ground motions for scenario large earthquakes on faults adjacent to the Santa Clara Valley. These simulations will also be applied to develop probabilistic seismic hazard maps for the Santa Clara Valley, using the Working Group 2002 results on earthquake probabilities for each fault.

\section{References on the San Jose Dense Seismic Array}

Frankel, A., D. Carver, E. Cranswick, T. Bice, R. Sell, and S. Hanson (2001). Observations of basin ground motions from a dense seismic array in San Jose, California, Bull. Seism. Soc. Am., v. 91, pp. 1-12. Ground-motion movie on http://groundmotion.cr.usgs.gov

Hartzell, S., D. Carver, R. Williams, S. Harmsen, and A. Zerva (2003). Site response, shallow shear-wave velocity, and wave propagation at the San Jose, California, dense seismic array, Bull. Seism. Soc. Am., v. 93, pp. 443-464.

All of the San Jose Urban Seismic Array data is now available online. Directions for retrieval: FTP ghtftp.cr.usgs.gov

Login: anonymous

Password: your email address

$>$ cd pub/OUTGOING/Carver/San Jose

get file name

The data are available in the original evt data format plus ASCII and SAC formats. All of the event-file headers contain correct station and instrumental parameters but no other processing has been done to the time series data. 


\section{A 100-YR AVERAGE RECURRENCE INTERVAL FOR THE SAN ANDREAS FAULT, SOUTHERN SAN FRANCISCO BAY AREA, CALIFORNIA}

Fumal, T E, Dawson, T E, Flowers, R, Hamilton, J C, Kessler, J, Samrad, L U.S. Geological Survey, MS 977345 Middlefield Rd., Menlo Park, CA 94025

Heingartner, G F San Jose State University, Department of Geology, San Jose, CA 95192

Reidy, L M, U. California Berkeley, Dept. of Earth and Planetary Science, Berkeley, CA 94720-4767

Seitz, G G, Southon, J, Lawrence Livermore National Laboratory, 7000 East Avenue, L-397, Livermore, CA 94551

Paleoseismic excavations at Mill Canyon and Arano Flat, two sites $0.6 \mathrm{~km}$ apart on the San Andreas fault near Watsonville, California, provide the first high-resolution chronology of large earthquakes on the Santa Cruz Mountains segment of the fault.

At Mill Canyon, a 2-m-wide zone of faulting has deformed latest Holocene deposits consisting of well-sorted sand and gravel interbedded with poorly sorted, commonly organic-rich debris flows ponded behind a small shutter ridge. We found evidence for the 1906 San Francisco earthquake and three additional ground-rupturing earthquakes since about 1500 A.D. Radiocarbon ages and pollen analyses indicate that the penultimate earthquake at this site occurred about 1700-1770 A.D. This indicates that the 1838 San Francisco peninsula earthquake did not rupture this portion of the fault.

At Arano Flat, faulting is expressed as a 1 to 2-m-wide zone that deforms alluvial fan deposits overlying well-bedded overbank deposits. We found evidence at this location for at least nine earthquakes since about 1000 A.D. We constrain earthquake ages using a chronological model incorporating AMS radiocarbon ages of 113 samples of detrital charcoal from 19 layers and stratigraphic ordering. The mean recurrence interval is about 105 years, while individual intervals range from about 10-310 years.

Two offset features at Arano Flat provide slip-per-event and slip rate data. A partially buried channel containing bottles from 1887-1890 is offset $3.5 \mathrm{~m}$. Given that we found no evidence at either site for the 1890 M 6.3 earthquake, which produced surface rupture on the San Andreas fault southeast of Parajo Gap, this entire slip may have occurred during the 1906 earthquake. This value is unexpectedly high compared to the geodetic estimate of 2.3-3.1 m for the slip at depth (Thatcher et al., 1997) or the geologic estimate of 1.7-1.8 m of surface slip at Wright's tunnel (Prentice and Ponti, 1997), about $33 \mathrm{~km}$ northwest of Arano Flat. A fold that formed during two earthquakes, most recently about 1400-1470 A.D., is offset about $10.5 \mathrm{~m}$ during the past five earthquakes. This yields a slip rate of $20.5 \pm 1.5 \mathrm{~mm} / \mathrm{yr}$, significantly higher than values previously used for this segment. Average slip for the four earthquakes prior to 1906 is $1.8 \mathrm{~m}$ indicating $\sim$ M7. Thus the mean recurrence interval is half the value used by the Working Group on California Earthquake Probabilities (WG 03) for earthquakes of this magnitude on the Santa Cruz Mountains segment.

$* * *$ 


\section{IMAGING PATTERNS OF FAULT CREEP: IMPLICATIONS FOR EARTHQUAKES ON THE HAYWARD FAULT}

Kevin P Furlong ${ }^{1}$, Rocco Malservisi ${ }^{2}$, Christine Gans ${ }^{1}$

${ }^{1}$ Geodynamics Research Group, Department of Geosciences, Penn State

${ }^{2}$ RSMAS, University of Miami

The slip deficit that accumulates on a fault constrains the potential slip (and moment) for subsequent earthquakes on the fault. Fault creep will reduce the rate at which this slip deficit accumulates, at least on those patches of the fault that undergo such aseismic slip. Mapping the spatial and temporal patterns of such creep then becomes an important component of assessments of earthquake potential on a fault such as the Hayward. In regions where faults are creeping at or near the surface, the pattern of surface deformation can be used to constrain fault creep in the upper few kilometers. Determination of the patterns of creep on deeper sections of a fault is poorly constrained by near-fault surface observations. The inclusion of micro-seismicity in analyzing patterns of fault creep adds an additional constraint on locations of locked and creeping patches on the fault.

A second consideration in assessing the accumulation of slip deficit is the potential for timedependent creep behavior - particularly driven by post-earthquake viscous relaxation. We are investigating the potential role of such transient behavior in both biasing observations of creep rate, and also modifying the rate at which slip deficit accumulates. Including the effects of a simulated 1868-like earthquake in our models of Hayward Fault creep indicate a significant variations in both the spatial pattern and rate of fault creep during the first 50-100 years after the earthquake.

$* * *$ 


\section{THE NORTHERN CALIFORNIA EARTHQUAKE DATA CENTER}

Lind Gee (UC Berkeley) and David Oppenheimer (USGS)

The Northern California Earthquake Data Center (NCEDC) is a joint project of the University of California Berkeley Seismological Laboratory (BSL) and the United States Geological Survey (USGS). The NCEDC is a long-term archive and distribution center for seismological and geodetic data for Northern and Central California and is supported by the Berkeley Seismological Laboratory and funding from the USGS component of the National Earthquake Hazards Reduction Program (NEHRP).

The NCEDC serves as an on-line archive for various types of digital data relating to earthquakes from a variety of networks and organizations. Although the primary focus of the NCEDC is northern and central California, several data sets include sites in southern California, Oregon, Washington, Alaska, and Hawaii. The data sets include earthquake catalogs, seismograms, GPS time series, and other geophysical data sets including strain, tilt, and creep.

Data from the NCEDC are freely available over the Web using a number of tools. A major effort is underway to convert the NCSN waveform data to MiniSEED format. When completed, the conversion will allow nearly all waveform data at the NCEDC to be accessed using a common set of tools. We are also actively working to convert the NCSN and BDSN earthquake catalogs into a database format. When completed, this will allow integrated access to the catalogs, parametric and waveform data.

The NCEDC is available at http://quake.geo.berkeley.edu. 


\title{
A POSSIBLE LONG-TERM PALEOSEISMIC EARTHQUAKE RECORD ALONG THE NORTHERN SAN ANDREAS FAULT BASED ON TURBIDITE STRATIGRAPHY
}

\author{
C. Goldfinger ${ }^{1}$, C. H. Nelson ${ }^{2}$, J. Chaytor ${ }^{1}$, J. Johnson ${ }^{1}$, D. Ericsson ${ }^{1}$, A. Morey-Ross ${ }^{1}$ \\ And the 37 member Shipboard Scientific Party \\ ${ }^{1}$ College of Oceanic and Atmospheric Sciences, Oregon State University, Corvallis, Oregon \\ 97331; 541.737.5214. contact email: gold@ coas.oregonstate.edu \\ ${ }^{2}$ Formerly USGS, now at Instituto Andaluz de Ciencias de la Tierra, Granada, Spain odp@ugr.es
}

During June and July, 2002, we collected 60 cores from channel and canyon systems draining the northern California continental margin. The objective of this project is to test the hypothesis that many of the turbidites deposited in these channels result from turbid flows triggered by earthquakes on the northern San Andreas Fault (SAF). Along the northern coast of California between San Francisco and Point Delgada, the San Andreas lies close to the coast or just offshore. No regional stratigraphic datum has yet been found in our cores, however correlation of individual turbidites both along individual channels and across non-connecting channels is robust, providing numerous stratigraphic ties between these systems. We are using Gamma density, p-wave velocity, high-resolution magnetics, $x$-ray, mineralogic, and color reflectance data to build a comprehensive regional correlation along the length of the northern San Andreas. That we are able to correlate individual turbidites along channels is not surprising, however correlating turbidites from one channel to another, some as much as $300 \mathrm{~km}$ apart, is surprising. Correlation of events along the margin for large distances suggests an earthquake origin for these turbidites, since other potential triggering mechanisms (except perhaps very large storms) operate in only single channels. Such synchronous triggering over a wide region is shown for many events. Channels from separate mineralogic provenances come together at confluences, below which we see either doublets, with no intervening time (hemipelagic sediment) between them, or bimodal coarse fractions in single turbidites, each density and magnetic peak representing a separate provenance. The mixing of flows from distinct provenances into single turbid flows below confluences also demonstrates synchronous triggering of separate channel systems. Similar relationships have been recognized in the Sea of Japan. Perhaps of equal or greater importance, the regional correlation of events implies that the physical property "wiggles" contain information about the earthquakes themselves, since the turbidites located in widely separated and noncommunicating channels have, to our knowledge, little else in common. We suggest that the information contained in these wiggles may be the energy signature of the earthquake itself, in effect a geo-seismogram.

Based on assigning initial AMS $14 \mathrm{C}$ results to the regional correlation, we find that regional correlation is possible for the last $\sim 6200$ years, which will likely be extended to $\sim 10,000$ years as the project matures. Thus far we are able to correlate 35 events above this age datum for the entire region. Of these, 10 events can be correlated along the length of the study region, from the northern limit of the SAF to south of San Francisco. Twelve events correlate along a northern "segment" and nine events correlate along a southern "segment" We find no events that occur clearly in only one channel, and only four events that are found in two and three channels only. These events are in close proximity to the seismically active Mendocino Triple Junction, and probably are related to local earthquakes there. The "segment boundary" along the SAF, if such exists, lies between Point Reyes and Point Arena.

$* * *$ 


\section{NORTHERN CALIFORNIA ACTIVE FAULT MAP DATABASE}

Russell W. Graymer

U.S. Geological Survey, Menlo Park, CA 94025

In 2004 scientists at USGS, in cooperation with CGS, university and industry geoscientists, are starting a new task, to prepare a new active fault map database for Northern California. The initial charge to this task will be to complete an initial product before the $100^{\text {th }}$ anniversary of the April, 1906, great San Francisco earthquake. Furthermore, the product must be compatible with the National Fault Database. Because of the time constraints involved, we will initially focus on the greater San Francisco Bay region, including Santa Cruz and northern Monterey Counties.

Although the details of the task are still in the planning stage, we currently anticipate a three-fold effort: (1) detailed mapping of known active faults, (2) mapping and categorization of all faults, and (3) projection of important fault surfaces down into the upper crust. The results of each part of the task must be fully integrated into each of the other parts. For example, detailed trace maps must be integrated into the regional maps produced for the second sub-task.

Maps of active fault traces are available for many portions of the region. The goal for the detailed mapping sub-task will be to compile existing maps, identify areas where new mapping is needed, do that new mapping and integrate it into the database. A critical early step will be to generate consensus on what types of fault-related features to include, how to capture levels of uncertainty inherent in the identification of fault features, and how to resolve potential conflict between multiple maps of the same fault section. The digital nature of the product raises the potential to retain multiple working hypotheses.

New regional and quadrangle-scale geologic maps published over the past decade make it possible to produce a preliminary map and database of all faults in the region, integrating the results of the first sub-task and emphasizing faults of unknown, but potentially recent, activity. The main challenge here will be to delineate what types of information to capture in the fault database and to decide how to extrapolate information along the length of a fault. By going beyond the known active faults, this map database will be an important resource for future fault studies and response to unanticipated earthquakes.

The third sub-task will be to project the major fault surfaces into the upper crust. Recent work and recent earthquakes have shown that traditional maps of faults at the Earth's surface may provide ambiguous information about faults in the subsurface, insufficient, for example, to identify the seismogenic fault or understand fault interactions. Furthermore, a full 3-D fault geometry will enhance the usefulness of the fault map database for various types of modeling. Work over the past two years on the Hayward and Calaveras Faults has shown that seismic, geologic, and geophysical data can be combined to project fault surfaces into the upper crust. The main challenges for this sub-task will be to collect and analyze the required data, and to decide how to best handle the inevitable ambiguity.

$* * *$ 


\title{
LOW SLIP-AT-A-POINT VARIABILITY: IMPLICATIONS FOR EARTHQUAKE-SIZE DISTRIBUTION, FAULT RUPTURE HAZARD, AND GROUND-MOTION MODELING
}

\author{
Suzanne Hecker, U. S. Geological Survey, Menlo Park, CA, shecker@usgs.gov \\ Norman A. Abrahamson, Pacific Gas and Electric Company, San Francisco, CA, \\ naa3@earthlink.net
}

Analysis of a composite geologic data set (521 observations from 180 sites) shows that event-toevent variability in slip at a point on a fault is less than expected from a Gutenberg-Richter (G-R) distribution of earthquake sizes and less than assumed in fault rupture hazard evaluations. The narrow range in slip at a point implies that slip patterns repeat and thus distributions of rupture asperities, which govern ground motions, also repeat.

We estimate the coefficient of variation ( $\mathrm{CV}$, the standard deviation divided by the mean) of slip at a point by assuming that the $\mathrm{CV}$ is constant for all sites or a subset of sites to allow for statistical analysis. Direct calculation of the CV for all sites yields a value of $0.45 \pm 0.02$. We can show that this estimate is unbiased, even given the small number of observations per site. We compare this result to expected values for the Characteristic and G-R models of earthquake occurrence. We use a forward modeling approach- in which we consider the effect of sampling slip at a point instead of having direct measurements of earthquake magnitudes on a fault. Two factors that could produce variability in slip at a point that is less than the actual variability in earthquake size are: 1) moderate-size earthquakes are less likely than large earthquakes to rupture through a particular site; 2) small-slip ruptures that pass through a site are less likely than large-slip ruptures to be detected as discrete events. A factor that could produce variability in slip at a point that is greater than the variability in earthquake size is variability in slip pattern (that is, variability in the distribution of slip from event to event). The modeling results are most sensitive to: 1) variability in slip pattern, 2) variability in slip as a function of magnitude, and 3) the threshold of event detection. To produce $\mathrm{CV}$ values consistent with the data requires that the slip-magnitude relation have a standard deviation much smaller than that commonly assumed from global earthquake data and that the slip pattern have much less variability than the variation along strike in a single earthquake. Small standard deviations imply that slip at a point and rupture pattern are repeatable for a given magnitude. Because each of the exponentially distributed magnitudes would have to have characteristic slip and characteristic slip pattern, we conclude that the G-R model can be rejected as a model for the occurrence of earthquakes on individual faults.

We are in the final stages of data anaylsis and plan to submit a manuscript on our research to a peer-reviewed journal by the end of 2004. Upon publication , the slip-at-a-point data set will be made available via the world wide web.

$* * *$ 


\section{ASSESSMENT OF LATE QUATERNARY DEFORMATION, EASTERN SANTA CLARA VALLEY, SAN FRANCISCO BAY REGION}

C.S. Hitchcock and C.M. Brankman (William Lettis \& Associates, Inc., 1777 Botelho Drive, Ste. 262, Walnut Creek, CA 94596; 925-256-6070)

A series of northwest-trending reverse faults within the East Valley thrust fault system that bound the eastern margin of Santa Clara Valley are associated with the southern termination of the Hayward fault, and have been interpreted as structures that may transfer slip from the Calaveras fault to the Hayward fault. Uplift of the East Bay structural domain east of Santa Clara Valley is accommodated by this thrust fault system, which includes the Piercy, Coyote Creek, Silver Creek, Evergreen, Quimby, Berryessa, Crosley, and Warm Springs faults. Retrodeformable geologic cross sections provide constraints on the down-dip geometry and depth of interaction between faults of the East Valley thrust system and the Hayward and Calaveras fault systems. Based on the mapped geomorphic expression of the reverse faults along the base of a relatively linear, actively uplifting range front, it is possible that at least several of these faults are active, potentially seismogenic structures. However, stream terrace profiling and geomorphic map features suggest that faults within the East Valley thrust system experience repeated, minor offset and likely only rupture in secondary response to large earthquakes on the nearby Hayward and Calaveras faults and, thus, may not be fully independent seismic sources. Integration of this geomorphic and structural information has helped define the style of strain transfer at the southern end of the Hayward fault and quantified the magnitude and rate of shortening on the East Valley thrust system.

NEHRP Award Number 01-HQ-GR-0034

$* * *$ 


\section{CHARACTERIZATION OF SUBSURFACE SEDIMENTS, SOUTHERN SAN FRANCISCO BAY AREA, CALIFORNIA}

Christopher S. Hitchcock and Edward J. Helley (William Lettis \& Associates, Inc., 1777 Botelho Drive, Ste. 262, Walnut Creek, CA 94596; 925-256-6070)

Our GIS-based interpretation of compiled subsurface data show the elevation of the buried top of Pleistocene deposits and thicknesses of Holocene deposits along the San Francisco Bay margins. The top of buried Pleistocene deposits likely represents a surface exposed prior to the rise of seawater through the Golden Gate at the beginning of the Holocene. The primary basis for identifying the top of Pleistocene unconformity, now generally covered by Holocene sediments, is based on the consolidation of Pleistocene deposits during subaerial exposure following lowering of water levels in the Bay during the last sea level low stand. This period of exposure of a relatively stable landscape is distinguished by the development of a distinct pedogenic soil horizon. Soil development within Pleistocene deposits, now buried, is associated with a notable increase in density, and changes in color and texture, that are identifiable in standard geotechnical boring logs and are consistent across varied deposits formed within different geologic environments along the Bay margins. Reconstructing the buried Pleistocene landscape provides information on the subsurface structure and stratigraphy of basins along the margins of the San Francisco Bay. Contour maps of the top of Pleistocene deposits show irregularities in the inferred Pleistocene surface that likely correspond to buried former stream channels, based on historic locations of streams along the Bay margins. In addition, reconstruction of this laterally extensive surface provides a unique and important strain gauge for evaluating the location and style of Holocene deformation along the Bay margins and, therefore, may contribute to our understanding of the structural origin of the San Francisco Bay.

NEHRP Award Number 99-HQ-GR-0097

$* * *$ 


\section{ASSESSMENT OF SEISMOGENIC SOURCES BETWEEN THE RODGERS CREEK AND SAN ANDREAS FAULTS, NORTHWESTERN SAN FRANCISCO BAY REGION, SONOMA COUNTY, CALIFORNIA}

C.S. Hitchcock and K.I. Kelson (William Lettis \& Associates, Inc., 1777 Botelho Drive, Ste. 262, Walnut Creek, CA 94596; 925-256-6070)

Based on detailed geomorphic mapping and analyses, we provide constraints on the distribution of late Quaternary strain in the region between the Rodgers Creek and San Andreas fault zones in the northern San Francisco Bay Area, south of the Russian River. The regionally extensive, $6 \mathrm{Ma}$ Wilson Grove Formation provides a datum for assessment of long-term deformation. Deposition of the Wilson Grove Formation apparently occurred on a surface of low to moderate relief beveled across Franciscan basement rock, likely within a shallow marine embayment. The base of the Wilson Grove formation is offset across the northwest-trending Americano Creek, Bloomfield, Joy Creek, Dunham, Tolay, and Burdell Mountain faults. Contours on the base of the Wilson Grove formation are consistent with regional uplift across the Sebastopol structural block, with maximum uplift within the western and central portions of the block. This uplift is localized in the areas adjacent to the Bloomfield fault and east of the San Andreas fault. Longitudinal profiles of Pleistocene and younger stream terraces show localized warping and uplift coincident with loci of deformation within the Wilson Grove formation. Additionally, valley height to valley-floor width ratios reveal changes in stream valley morphology along Salmon, Americano, Stemple, and Walker creeks across the Bloomfield fault and near the San Andreas fault. The observed pattern is consistent with a response of these fluvial systems to localized late Quaternary uplift. These uplifts represent strain between the San Andreas and Rodgers Creek faults, and may be the result of large-scale interactions between these two major faults.

NEHRP Award 1434-HQ-97-GR-03153

$* * *$ 
QUANTITATIVE LIQUEFACTION HAZARD MAPS: SAN FRANCISCO BAY AREA, CA

Thomas L. Holzer, Michael J. Bennett, Thomas E. Noce, John C. Tinsley, III U.S. Geological Survey, 345 Middlefield Road, Menlo Park, CA 94025

The Problem: As has been demonstrated repeatedly by historical earthquakes in the San Francisco Bay area, liquefaction of artificial fills and fluvial deposits is a significant hazard to the built environment. Methodologies for mapping this hazard at regional scales remain very qualitative. State seismic liquefaction hazard zonation maps only identify whether or not a location is in or out of a potential liquefaction zone. Liquefaction hazard maps based on maps of surficial geology typically characterize the hazard in degrees ranging from low to high. We are developing a mapping methodology that quantifies the hazard posed by geologic units at regional scales.

What has been learned: We have been evaluating the feasibility of using a parameter known as the liquefaction potential index (LPI) by calibrating the parameter and testing its application in pilot liquefaction mapping projects. We compute LPI from cone penetration test (CPT) soundings. Using data from USGS post-earthquake geotechnical exploration of liquefaction and nonliquefaction sites in 1989 Loma Prieta earthquake, we have calibrated LPI as a predictor of liquefaction. Using this calibration of LPI, we have produced liquefaction maps for the greater Oakland region (as part of Project Impact) that estimate the percent of area underlain by specific surficial geologic units that will exhibit surface manifestations of liquefaction, i.e., sand boils, ground cracking, and lateral spreading, during Hayward Fault scenario earthquakes. The predictions of the map are generally consistent with previous earthquake experience. The methodology has also been used to predict the performance of the artificial fills in the Oakland area during the Loma Prieta earthquake with excellent agreement between observation and prediction. The maps also stand as bench mark predictions to be used to evaluate the methodology when the Hayward Fault actually ruptures.

Products produced and data accessibility: Hazard maps using the LPI methodology have been published for Alameda, Berkeley, Emeryville, Oakland, and Piedmont as USGS OFR 02-296, which is available digitally at http://geopubs.wr.usgs.gov/open-file/of02-296/. CPT data are available on the USGS Quake Web site (http://quake.usgs.gov/prepare/cpt/alameda. htmil). The calibration study was published in 2003 in the ASCE Journal of Geotechnical and Geoenvironmental Engineering.

Status of project: CPT data are being collected in the northern Santa Clara Valley and are being analyzed. LPI distributions of geologic units are almost complete. Our short-term plan is to apply the LPI methodology in the northern Santa Clara Valley to produce both a probabilistic liquefaction hazard map and a scenario type map like that produced for Oakland. As we get more familiar with characterizing surficial geologic units around the Bay margins, we anticipate that fewer CPT soundings will be required and mapping efficiency will improve. Our long-term plan is to produce a complete mapping of the liquefaction hazard around the Bay margins with both probabilistic and scenario approaches and to extend the methodology to map areas susceptible to lateral spreading.

$* * *$ 


\title{
THE 3-DIMENSIONAL GEOLOGIC MAPS AND VISUALIZATION PROJECT
}

\author{
R. C. Jachens, U.S. Geological Survey, Menlo Park, CA 94025
}

The USGS recently began a long-range project to develop and produce 3-D geologic maps that can serve as the basis for quantitative computer modeling of a wide range of physical processes. This large project (with about 25 participants) includes tasks focused on traditional geologic mapping, developing techniques for constructing 3D geologic models, defining uncertainties associated with geologic elements and properties, constructing a 3D geologic map of the Santa Clara ('Silicon')Valley, southern San Francisco Bay area, California, and designing procedures for visualizing, accessing, working with, and releasing 3D geologic information. The multipurpose maps ultimately resulting from this project are intended to provide a quantitative basis for modeling processes such as groundwater flow, contaminant dispersion from naturally occurring mercury and asbestos, ground shaking, seismic wave propagation, and tectonic strain accumulation. The fundamental map architecture is defined by critical surfaces (faults, unconformities, other depositional contacts) interacting to form volumes, which ultimately are assigned measurement-based properties according to geologic identity, geometric position, or both. Quantitative definition of critical surfaces is based mainly on surface geology, drillhole data, cone penetrometer testing, gravity and magnetic modeling, seismic reflection and refraction profiling, and earthquakes. Critical surfaces are assembled into a 3D map using earthVision (TM Dynamic Graphics, Inc.) modeling software.

The Santa Clara Valley 3D map volume is $45 \mathrm{X} 45 \mathrm{~km}$ by $14 \mathrm{~km}$ deep, and spans the valley floor and surrounding hillsides from the San Andreas Fault to the Calaveras Fault. It is divided by 12 major faults into blocks, within which the Cenozoic section is represented by up to five layers, and the Mesozoic section by more than six units. The 3D map exists in the computer as: 1) a set of numerical grids that quantitatively define the positions and shapes of the critical surfaces; 2) a set of instructions that specify how these surfaces interact where they encounter each other; and 3) the software to assemble the surfaces according to the specified instructions and to assign properties to the map volume. The present 3D map includes the fundamental geometry, architecture, and interaction instructions, though many of the surfaces are as yet only approximately defined. This framework allows us to progressively refine the individual surfaces in an iterative fashion without altering the fundamental model architecture.

$* * *$ 


\section{SIGNIFICANT ROLE OF THE SILVER CREEK FAULT IN THE SAN ANDREAS SYSTEM, CALIFORNIA}

Jachens, R.C., Graymer, R.W., Wentworth, C.M., McLaughlin, R.J., U.S. Geological Survey, Menlo Park, CA 94025

A 40x10-km gravity low at the NE margin of Santa Clara Valley marks an extensional strike-slip basin (the Evergreen basin) between the Silver Creek Fault (SCF) and Hayward Fault (HF) that resulted from large right slip across this previously unrecognized right step in the San Andreas Fault system. Quaternary alluvium overlies the NW end where the gravity low is widest and of maximum amplitude ( -35 mGal), whereas Tertiary gravels and older bedrock crop out in places to the SE, where the low is less pronounced. Detailed seismic tomography (Michael, 1988) shows

low velocities extending down to $>4 \mathrm{~km}$ within the low, indicating that it results from a concealed basin of slow, and thus relatively young, sediments. Inverting the gravity with an iterative 3D basin-modeling method and a density/depth function from nearby Livermore Valley yields a 40-km-long model basin that narrows from 8 to $5 \mathrm{~km}$ and shallows from 6 to $4 \mathrm{~km}$ toward the SE. The basin is bounded on the NE by the southward extension of the HF system, and on the SW by the SCF. The NE boundary of the gravity-defined basin is characterized by NE-dipping reverse faults. Along the SW basin boundary, the southern half of the SCF is modified by SWdipping reverse faults, as indicated by gravity and magnetic anomalies interpreted in conjunction with exposed Franciscan rocks and Coast Range Ophiolite SW of the SCF. These relationships suggest that the transtensional right-step associated with basin formation has been superceded by a transpressional left-step, which is indeed the present configuration of the Calaveras-Hayward Fault junction based on seismicity. Pliocene gravels in the footwall block of the transpressional faults are the youngest basin sediments, suggesting that the transition from right- to left-step took place post-6 Ma. Some thrust faults are capped by Pleistocene to latest Pliocene gravels, indicating that the transition was largely complete by about 2 Ma.

We propose that the Evergreen basin formed in the wake of a right stepover from the SCF to the southernmost HF. Its length and regular, non-segmented morphology imply at least $40 \mathrm{~km}$ of right slip along the SCF and possibly much more. Palinspastic reconstruction of the 175 $\mathrm{km}$ of San Andreas Fault system offset partitioned to the East Bay fault system with at least $50 \mathrm{~km}$ accommodated on the SCF juxtaposes two dispersed 40-km-long, strongly magnetic, tabular bodies against each other across the SCF: serpentinite of Yerba Buena ridge/Oak Hill in Santa Clara Valley against a concealed, flat-lying body (inferred to be serpentinite) now NW of Parkfield, California. The timing of fault-junction transition described above suggests offset of over $100 \mathrm{~km}$ on the SCF.

$* * *$ 


\section{CONNECTING ASEISMIC SLIP AND MICROSEISMICITY ON THE CENTRAL SAN ANDREAS FAULT}

Ingrid A. Johanson and Roland Bürgmann

University of California, Berkeley

High precision micro-earthquake relocations have revealed seismicity structures that may be an indicator of the fault's slip characteristics. Characteristically repeating micro-earthquakes (CREs) within aligned streaks of micro-seismicity suggest that these structures delineate areas of active aseismic fault slip. A general inverse correspondence between zones of abundant microseismicity and the coseismic slip area of large earthquakes also implies a relationship between creep and micro-earthquakes. We test this relationship using geodetic measurements of near-fault deformation from GPS and InSAR. Such measurements allow for determination of locked and creeping sections of the fault. We focus on the central San Andreas fault (SAF) near San Juan Bautista; an area which experiences both aseismic and seismic fault slip and where there is a long history of geodetic measurements. Although aseismic slip on the central San Andreas is time dependent and has varied in response to regional earthquakes and in the form of slow earthquakes, for this presentation we solve for the secular creep rate between 1996 and 2000. We present the results of three joint inversions for fault slip, using a model with dislocations in an elastic half-space. For each inversion, we altered the fault segmentation scheme on the section of the SAF near San Juan Bautista. Model 1 treats the entire fault surface above the locking depth $(9-12 \mathrm{~km})$ as a single patch and divides the fault into only three segments along strike. In model 2 the fault is divided into a smaller grid, with 38 patches between $3 \times 6 \mathrm{~km}$ and $3 \times 7.5 \mathrm{~km}$. For model 3, we tried to follow seismicity streaks and other features as much as possible when drawing fault patch outlines. The patch sizes are therefore irregular and they tend to be elongated along strike. The joint inversion is capable of fitting the data slightly better (per degree of freedom) on the seismicity guided model (model 3) than on either model 1 or 2, though the differences are very small. However, the slip patterns obtained from joint inversions on models 2 and 3 both demonstrate a strong correspondence between steady creep and areas of abundant microseismicity.

$* * *$ 


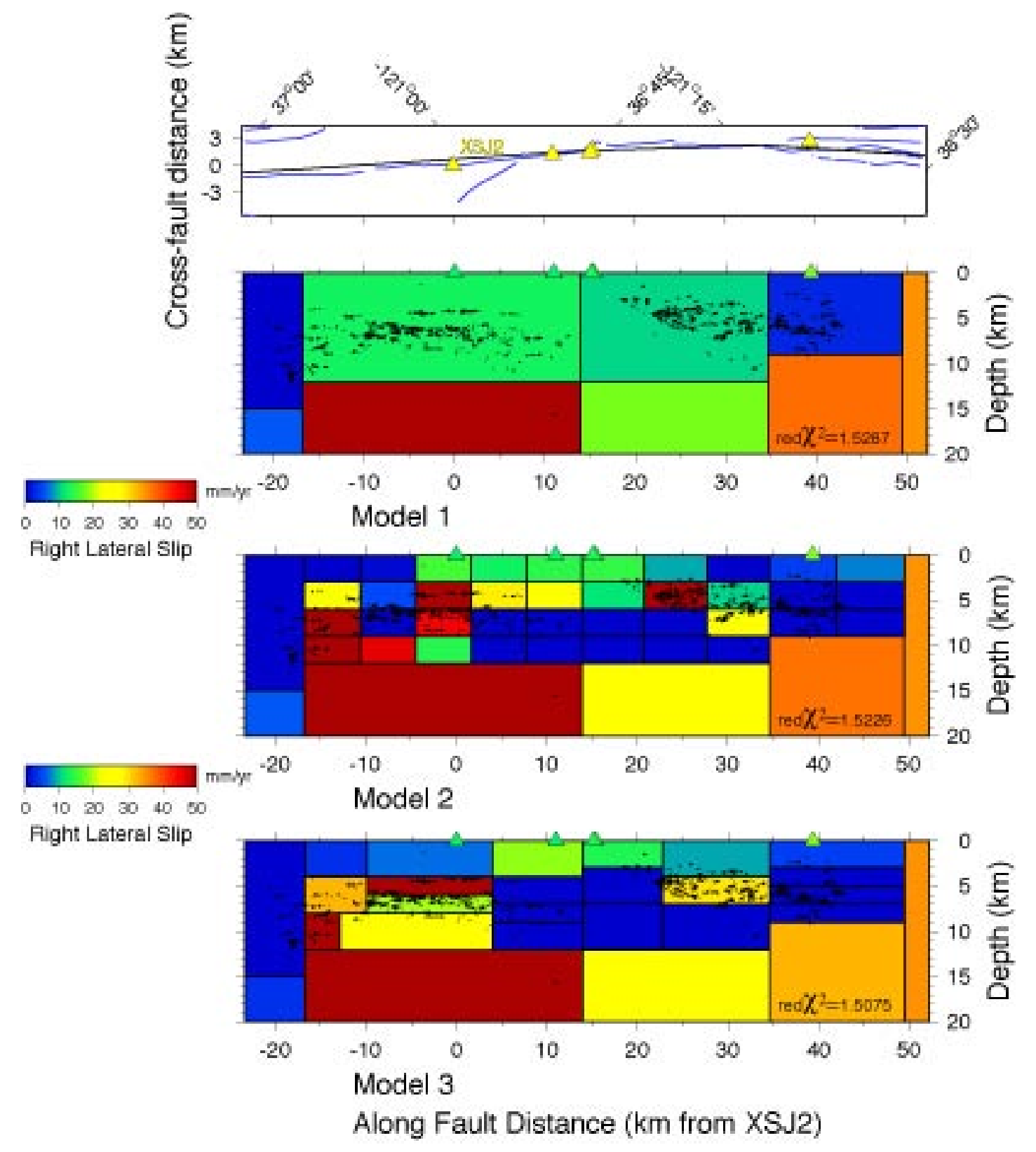

Figure 1: Results of three joint inversions of InSAR and GPS data for slip on the San Andreas fault near San Juan Bautista. Black circles are relocated microseismicity of Rubin and Gillard (JGR, 2000). Triangles are creepmeter location, in the profiles they are shown for comparison and have been colored according to their post-Loma Prieta earthquake rate. 


\title{
BOREHOLE TENSOR STRAIN AND PORE PRESSURE FROM SAN FRANCISCO MINI-PBO SITES: INITIAL RESULTS AND COMPARISON WITH OTHER USGS BOREHOLE STRAIN AND DEFORMATION DATA
}

\author{
M. J. S. Johnston*, G. D. Myren*, M. H. Murray** and R. J. Mueller* \\ (*U.S. Geological Survey, Menlo Park, CA 94025) \\ (**Seismology Lab., UCB, Berkeley, CA, 94720)
}

High-precision borehole strain, deformation and seismic monitoring have been an important part of the USGS monitoring program for the past 25 years. With the recent funding of the NSF Earthscope initiative, this type of monitoring will soon be implemented within the PBO component of Earthscope throughout the western US. The first prototype cluster of five borehole sites, usually referred to as Mini-PBO, was successfully installed along the San Andreas/Hayward fault system in the San Francisco Bay area from 2001-2003. Each 200m deep borehole was equipped with a tensor strainmeter, seismometer, pore pressure monitor, tiltmeter, GPS and temperature monitors. Initial results show 1) total moment release can be determined from strain offsets with local earthquakes down to M3,2) constraints can be placed on the geometry and depth of surface creep and the deep slip and/or slow earthquakes driving these events, 3) array observations of normal modes and free oscillations, and 4) constraints can be placed on the timescale and size of earthquake nucleation. Comparative noise spectra over nine decades of frequency (10E-7 to $100 \mathrm{~Hz}$ ) are determined using data from the tensor strainmeters and pore pressure transducers at each Mini-PBO location and compared with similar data obtained from other USGS borehole strain instruments in California in order to cross-compare data quality from different measurement systems. In particular, we compare the responses from the new Carnegie tensor strainmeters in the Mini-PBO sites with the Gladwin tensor strainmeters and Carnegie dilatometers at Parkfield. We also make the first measurements of pore pressure noise and determine the relations between pore pressure and strain, particularly during local and teleseismic earthquakes such as the November 3, 2002, M 7.9 Denali earthquake. The ten borehole strain instruments used are all installed at approximately 150-200 m depth. The general characteristics of power spectral density estimates obtained at all sites are similar with noise power decreasing with increasing frequency at roughly inverse frequency squared. Other than 10 $\mathrm{dB}$ microseismic noise peaks and 30 to $40 \mathrm{~dB}$ peaks at earth tidal frequencies, the spectra from the Parkfield instruments decrease from about $-80 \mathrm{~dB}$ at a frequency of $10 \mathrm{E}-8 \mathrm{~Hz}$ to about -220 $\mathrm{dB}$ at a frequency of $100 \mathrm{~Hz}$. Initial data from the Carnegie tensor strainmeters at the Mini-PBO sites appears to be about $10 \mathrm{~dB}$ noisier at frequencies between 10E-7 to $100 \mathrm{~Hz}$. Pore pressure and compressional dilational strain are in phase and are highly coherent at short to intermediate periods.

$* * *$ 


\section{EARTHQUAKE-INDUCED LANDSLIDES}

David K. Keefer ${ }^{1}$ and Scott B. Miles ${ }^{2}$

${ }^{1}$ Earthquake Hazards Team, US Geological Survey, Menlo Park, CA

${ }^{2}$ University of Washington, Seattle, WA

This presentation will describe three different aspects of ongoing earthquake-induced landslide investigations. First, the number of earthquakes worldwide with relatively complete documentation of landslides is surprisingly small. Such complete documentation is important because, for formulating hazard- and risk-reduction models, it is necessary to know which types of slopes DID NOT produce landslides as well as which types of slopes did fail. Thus, continued post-earthquake investigations are critical to building up this data base, and the first part of the presentation will briefly summarize recent post-earthquake landslide studies in Alaska, Mexico, Japan, and Peru. Second, studies of the 2001 Southern Peru earthquake (M 8.4) have provided significant new insights into the long-term effects of earthquake-induced landslides in the landscape there, which Keefer has been studying since 1995. These results will be summarized, and a case study in which analysis of the sedimentary record there may provide an indication of paleoseismic activity will be discussed. Third, a new model for evaluating the hazard from earthquake-induced landslides will be introduced. This model has been developed primarily by Miles. It incorporates both qualitative and quantitative data on landslides, and is capable of evaluating and mapping the very different types of hazards associated with the many different types of landslides triggered by earthquakes.

$* * *$ 


\section{PRIORITIES AND NEEDS FOR GROUND FAILURE RESEARCH- A CGS PERSPECTIVE}

Keith Knudsen

California Geological Survey, San Francisco, CA

The California Geological Survey has the statutory responsibility for creating hazard zonation maps for California. At present these maps simply show zones considered susceptible to liquefaction or landslide hazard, i.e. you are either "in" or "out" of a hazardous zone. With an eye toward more refined mapping of hazard susceptibility in the future, we have identified the following research priorities and needs.

Liquefaction-related research

- Methods of regional mapping based on expected deformation (not just susceptibility/ triggering)

- Quaternary deposits mapping (continue to improve/validate)

- Characterization of engineering geologic properties of Quaternary map units (including the variability within and between units)

- Compile data and produce maps of thickness of Holocene deposits and depth to top of Pleistocene

- To assist in researching these topics, CGS' borings database will be available soon

Landslide-related research

- Develop better ways to apply earthquake ground motion to landslide hazard mapping (Newmark displacement versus yield acceleration, probabilistic PGV, Arias Intensity)

- Research methods to remotely identify/predict the density \& orientation of fractures in crystalline bedrock (for example, using LIDAR)

- Develop generic landslide hazard mapping method - with all possible triggering mechanisms. Multiple methodologies should be explored (e.g. Bartlett and Youd, SHALSTAB, Newmark, and Harp and Noble) or a single unifying algorithm such as Fuzzy Logic.

- Develop a relationship between Steve Ellen's terrain-type mapping and shear strength parameters in an area where CGS data exists

- Develop spatial statistical shear strength parameters for major geologic units (using, in part, the CGS database)

- Test landslide hazard models against mapped slope failures from past earthquakes. Models:

- Fuzzy logic (Miles and Keefer, 2003)

- Multiple models (Wang, Keefer and Wang, 1998)

- Landslide Implementation Committee's pseudostatic screening method (Stewart, 2003)

- Digitally capture existing landslide maps at CGS and the USGS

- Geologic maps, landslide inventories \& historical landslides remain fundamental data input

- Collect and utilize high-resolution terrain data

Ground motion-related research

- Develop capability for amplification mapping

$* * *$ 


\title{
PALEOSEISMIC INVESTIGATION OF THE NORTHERN SAN GREGORIO FAULT AT PILLAR POINT MARSH NEAR HALF MOON BAY, CALIFORNIA
}

\author{
Richard D. Koehler, Gary D. Simpson, Robert C. Witter, Eileen Hemphill-Haley, and \\ William R. Lettis \\ William Lettis \& Associates, 1777 Botelho Dr., Suite 262, Walnut Creek, CA 94596
}

The 110-km-long northern San Gregorio fault system (SGF) is an active, northwest trending right-lateral strike-slip fault zone that extends from Monterey Bay to Bolinas Lagoon, California. Despite its significance, the SGF has received relatively little attention regarding its late Holocene paleoseismic behavior because much of the fault lies offshore. Data on the amount and timing of prehistoric earthquakes on the northern SGF are essential to evaluating probabilistic seismic hazard assessments for the San Francisco Bay Area.

Abrupt stratigraphic succession of fresh-brackish marsh soils and itertidal mud within Pillar Point marsh record evidence for sudden changes in relative sea level. The marsh lies within an inferred pull-apart structure between two right-stepping strands of the SGF along the northern margin of Half Moon Bay. Changes in the depositional environment are a function of sudden tectonic subsidence and gradual eustatic sea level rise. Diatom paleoecology and stratigraphic relations are used to evaluate the origin and timing of abrupt changes in the depositional record. Rapid submergence is indicated for two buried marsh surfaces by an abrupt change in diatom assemblage from fresh-brackish species below the contact to brackish marsh/tideflat species above the contact. The abrupt transition from a grassy meadow or dune field to a brackish marsh provides possible evidence for a third subsidence event. A sustained period of aggradation, abrupt upper contact, and a change in diatom assemblage from fresh brackish soil below the contact to a fresh-brackish pond above the contact indicates the possibility of a fourth subsidence event. We can not rule out, however, that erosion and alluvial deposition involved a shift to a wetter climatic period that formed a fresh-brackish pond unrelated to coseismic deformation. These data support the occurrence of at least two and possibly four Holocene earthquakes on the northern SGF. Radiocarbon analyses for deposits associated with the older subsidence events are necessary to provide a preliminary earthquake chronology for the fault.

Existing paleoseismic data on the northern SGF is compared with results of this study in order to evaluate the dates of prehistoric earthquakes. These data indicate that the most recent earthquake occurred between AD 1667 and 1802, synchronous with the date of the MRE determined at the nearby Seal Cove trench site. Therefore, the results obtained in this study demonstrate the utility of using marsh stratigraphic techniques to evaluate paleoearthquakes along strik-slip faults.

$* * *$ 


\section{A 2000-YEAR PRELIMINARY RECORD OF LARGE EARTHQUAKES ON THE SOUTHERN HAYWARD FAULT}

J J Lienkaemper (650-329-5642; email: jlienk@ usgs.gov); ${ }^{1}$ T E Dawson; ${ }^{1}$ P L Williams; ${ }^{2}$

S F Personius; ${ }^{3}$ Gordon G. Seitz; ${ }^{4}$ and David P. Schwartz ${ }^{1}$

${ }^{1}$ USGS MS 977, 345 Middlefield Rd., Menlo Park, CA 94025

${ }^{2}$ P. Williams \& Assoc., P.O. Box 1492 West Tisbury MA 02575

${ }^{3}$ USGS, Denver Federal Center, Denver CO 80225

${ }^{4}$ Lawrence Livermore National Laboratory, Livermore, CA 94551

The Hayward fault, a major branch of the right-lateral San Andreas fault system, traverses the densely populated eastern San Francisco Bay region, California. We are conducting a multiyear paleoseismic investigation to better understand the Hayward fault's past earthquake behavior. Our site is near the south end of Tyson's Lagoon, a sag pond formed in a right step of the fault in Fremont. Because the Hayward fault creeps at the surface, we identified paleoearthquakes primarily using features which we judge to be unique to ground ruptures or the result of strongground motion, such as the presence of fault-scarp colluvial deposits and liquefaction. We correlate the most recent event evidence to the historical 1868 M 6.9 earthquake, which caused liquefaction in the pond. We recognize nine additional paleoruptures since about $\mathrm{AD} 115( \pm 135 \mathrm{yr})$ and two earlier events as yet undated. Event ages were estimated by chronological modeling, which incorporates historical and stratigraphic information as well as radiocarbon and pollen data. The preliminary mean recurrence interval (RI) for these ten events is $195 \pm 15 \mathrm{yr}$. This longterm (AD 115-1868) RI is somewhat greater than a previously determined RI of $130 \pm 40 \mathrm{yr}$ for the period AD 1470-1868. Our event sequence includes event evidence from fault traces on both sides of the pond by tracing key stratigraphic units across. Our continuing work at this site focuses on carefully examining the possibility of missing events due to a hiatus in sedimentation to verify that the current record of paleoearthquakes is complete over the 2000 -yr period. More age data is still needed to refine and complete the chronologic model to characterize the aperiodicity of the recurrence interval for the southern Hayward fault.

Results of the Tule Pond trenching study can be viewed online at;

Lienkaemper and others, 2002, A Record of Large Earthquakes on the Southern Hayward Fault for the Past 500 Years, Bulletin of the Seismological Society of America 92, 7 2637-2658. http://www.seismosoc.org/publications/bssa.htm] (SSA members only download)

http://geopubs.wr.usgs.gov/map-mf/mf2386 (Tyson site logs and data, 2000)

http://geopubs.wr.usgs.gov/open-file/of03-488 (Tyson site logs and data, 2001-2003)

http://geopubs.wr.usgs.gov/open-file/of99-318 (Northern Hayward fault recurrence data)

$* * *$ 


\title{
THE RIGHT-RELEASING STEPOVER BETWEEN THE RODGERS CREEK- HEALDSBURG AND MAACAMA FAULT ZONES: MODELING THE EVOLUTION OF YOUNG PULL-APART BASINS ALONG THE NORTHERN PART OF THE EAST SAN FRANCISCO BAY STRIKE-SLIP FAULT SYSTEM
}

\author{
R.J. McLaughlin, A.M. Sarna-Wojcicki, U. S. Geological Survey, Menlo Park, CA 94025 \\ Insights from experimental analog models-
}

Recent laboratory studies (Dooley and McClay, 1997) have simulated pull-apart basin development and evolution along strike-slip faults by incrementally deforming clay layers above rigid "basement fault blocks". In the experiments, initial positions of the movable strike-slip basement fault blocks were varied to simulate different releasing sidestep geometries. Although overly simplistic in detail, these experimental models have features that are surprisingly analogous with features of the right-releasing stepover between the Rodgers Creek and Maacama fault zones. Together with stratigraphic and sedimentologic constraints on the timing of deposition in basins associated with the stepover area, the analogous experimental basins indicate a multiphase structural evolution for the right-step between the Rodgers Creek and Maacama faults.

At present, the Rodgers Creek fault to Maacama fault stepover is an overlapping right sidestep. The overlap is defined on the SW by the mapped extent of the Rodgers Creek and Healdsburg faults northwestward to the vicinity of Lytton. On the NE, the overlap includes the southeasternmost extent of the Maacama fault, from the vicinity of Geyserville on the NW, to the north side of Rincon Valley and the city of Santa Rosa on the SE. The overlap of these two principal deformation zones is about $155^{\circ}$, closely matching an experimental $150^{\circ}$ overlap model of Dooley and McClay (figs. 2-8 in Dooley and McClay, 1997). An incipient basin which is associated with the lengthening overlap of the stepover faults and is partly defined by a local gravity low in southeastern Alexander Valley, is of similar orientation to that of the $150^{\circ}$ overlap basin model of Dooley and McClay.

In contrast, the orientation and dimensions of the geomorphically youthful Rincon Valley pullapart basin beneath Santa Rosa, closely matches the geometry of experimental non-overlapping, $30^{\circ}$ releasing sidestep basin models.

Right-releasing strike-slip basin development appears to have begun along the Maacama fault in the Little Sulphur Creek area NE of Geyserville, between about 2 and 2.5 MA. The late Pliocene and Pleistocene alluvial fill of Little Sulphur Creek basins is now uplifted, warped and dissected, and clearly more mature structurally, than Rincon Valley basin and the southeastern Alexander Valley basin, which contain thin sedimentary fills of Pleistocene to Holocene age that are comparatively only mildly deformed and dissected. Thus, although all three strike-slip basins formed sequentially in the same right-sidestepping, northwardly propagating transform setting, the younger strike-slip basins (Rincon Valley and Alexander Valley pullaparts) developed behind and southwest of somewhat older basins (the Little Sulphur Creek pullaparts). This sequence of basin development is not consistent with simple dextral right-stepping fault models. A more complex sequence of basin development is indicated, and other faults in addition to the Maacama and Rodgers Creek faults were also apparently involved.

The Bennett Valley fault, which now extends southeastward from Rincon Valley, may have been the fault from which the right-step to the Maacama fault originally developed. By analogy 
to the experimental models of Dooley and McClay and from geologic constraints, the Rincon Valley pullapart probably formed in the early to middle Pleistocene, from a releasing sidestep between the Bennett Valley and Maacama faults. The timing of basin formation is constrained by the oldest unfolded alluvial fill of Rincon Valley, assigned an age bracketed between 1.8 and $0.5 \mathrm{Ma}$ (Knudsen and others, 2000), though it is likely that these deposits are considerably younger than 1.8 Ma. The Rincon Valley pull-apart basin itself formed when N-trending Riedel shears developed SW of the right sidestep between the Maacama and Bennet Valley faults. The Riedel shears evolved into the present normal faults bounding the east and west sides of Rincon Valley, in conjunction with the progression of right slip along a newly evolving Rodgers CreekHealdsburg fault zone to the southwest. This non-overlapping $30^{\circ}$ releasing sidestep geometry may predate, or have evolved simultaneously, with the immaturely developed $155^{\circ}$ overlapping sidestep described above, in southeastern Alexander Valley.

\section{Structural model-}

The right-releasing stepover area and associated basins between the Rodgers Creek-Healdsburg and Maacama fault zones is modeled as a multiphase right-lateral stepover, superposed on basin structures formed within a pre-transform forearc setting that persisted in the corridor from Santa Rosa to Healdsburg until about 2 million years ago. Here, the stepover faults are the focus of interest.

Constraints on the timing of faulting from studies of the volcanic and sedimentary stratigraphy, radiometric dates, tephrochronology and sedimentologic data, provide a structural framework within which amounts of fault offset and slip rates since the late Pliocene may be established. Quaternary slip rates since the middle Pleistocene are also estimated for the youngest faults of the stepover area.

The structural model proposed here assumes that the Maacama fault zone is the northeastern principal deformation zone of the stepover area and that it was initiated between $2.5 \mathrm{Ma}$ (youngest Sonoma volcanism) and about 2.0 Ma (slightly younger than the Sonoma Volcanics and the known ages of obsidian clasts in overlying gravels that clearly were deposited prior to initiation of strike-slip faulting. Gravels in Little Sulphur Creek strike-slip basins northeast of Geyserville, were deposited syntectonically with early slip ( $\leq 2 \mathrm{Ma}$ ?) on the Maacama fault (McLaughlin and Nilsen, 1982; Nilsen and McLaughlin, 1985). The sedimentary fill of the Little Sulphur Creek right-releasing strike-slip basins has been uplifted, mildly compressed and dissected. During this deformation, it is assumed that the Maacama fault was the northeastern fault of a right-step from the Bennett Valley fault zone southeast of Santa Rosa.

The southwestern principal deformation zone of the stepover area now, is the Rodgers Creek -Healdsburg fault zone, which is apparently a somewhat younger structure than the MaacamaBennett Valley fault zone. The timing of initiation of the Rodgers Creek-Healdsburg fault zone is interpreted to be indicated by the age of relatively undeformed fill in the Rincon Valley pullapart basin and on uplifted surfaces around the edge of the basin. These Pleistocene and Holocene alluvial fan deposits are terraced due to several episodes of incision in conjunction with normal faulting along north trending faults which bound the east and west sides of Rincon Valley, connecting the southern Maacama fault with the Rodgers Creek-Healdsburg fault zone. These extensional faults and the associated $30^{\circ}$ underlapped right -side-step pull-apart (Rincon Valley) basin are interpreted to have evolved from cross-basin Riedel shears as slip on the Rodgers CreekHealdsburg fault zone evolved. The relatively flat Pleistocene to Holocene basin fill is early 
to middle Pleistocene ( 1.8-0.5Ma) age and younger, so that the width of RinconValley basin (about $3 \mathrm{~km}$ ) represents an approximate amount of extension since basin formation and inception of the Rodgers Creek-Healdsburg fault zone. The length of the Maacama and Rodgers CreekHealdsburg faults bounding the northeast and southwest sides of the Rincon Valley pull-apart basin (about $5 \mathrm{~km}$ for the Maacama fault and about $6 \mathrm{~km}$ for the Rodgers Creek-Healdsburg fault) are interpreted to represent approximate amounts of strike slip along the respective principal bounding strike-slip deformation zones since the mid-Pleistocene.

The stepover structure is here considered to be bounded by the Maacama fault on the northeast for about $40 \mathrm{~km}$, from about Rincon Valley on the southeast, to Geyserville on the northwest. The southwest side of the stepover is considered to be bounded by the Healdsburg-Rodgers Creek fault zone, also for about $40 \mathrm{~km}$, from the southeast side of Rincon Valley to about Lytton to the northwest. The extent of the stepover area is in part defined by the distribution of seismicity between the Maacama and Rodgers Creek-Healdsburg faults, particularly the distribution of shocks and aftershocks associated with several minor earthquake swarms and clusters in the area (for example a north trending alinement of several M 3- 4 earthquakes near Geyserville). The northward trends of several of these earthquake clusters may be associated with Riedel shears in the crust that could evolve into bounding cross faults of active right-releasing sidestep basins, similar to the Rincon Valley pull-apart.

The proposed area encompassed by the releasing sidestep between the Rodgers CreekHealdsburg and Maacama faults ( $40 \mathrm{~km}$ long by about 6 to $7 \mathrm{~km}$ wide between the two primary strike-slip deformation zones) is associated with distributed seismicity that clusters above a depth of about $10 \mathrm{~km}$ along various deformation zones including the Riedel shear cross structures. The $10 \mathrm{~km}$ depth limit of earthquakes may be used to define a stepover region with a crustal volume of about $2400-2800 \mathrm{~km}^{3}$. An approximately $10 \mathrm{~km}$ seismogenic depth limit is also used here, to establish moment magnitude potentials of various faults of the stepover area using the regression plots of Wells and Coppersmith (1994), and assuming that potential surface rupture lengths for the faults correspond to the limiting dimensions of the stepover area.

\section{Late Pliocene and Quaternary displacements and slip rates-}

Offset rates of the active faults associated with the right releasing sidestep between the Rodgers Creek and Maacama faults are constrained by the structural framework outlined above and constraints on amounts and timing of offsets from geologic map relations, sedimentologic data, radiometric dates and tephrochronology. The slip rates are derived from 3 independent data sets: 1.) offset of correlative stratigraphic sections; 2.) obsidian clast assemblages in gravels displaced across the faults from in-place obsidian sources; and 3.) offset rates derived from pull-apart basin geometry and the above structural model. The slip rates for the stepover area and criteria used to derive them are outlined below.

\section{Maacama-Bennett Valley Fault Zone-}

Several sets of criteria may be applied to constrain offset and rates of slip on the Maacama fault. As discussed above, based largely on sedimentologic relationships observed in the stepover region between Santa Rosa and Geyserville, the Maacama fault appears to have been initiated no earlier than 2.0-2.5 MA and it probably has experienced at least 2 phases of evolution. The initial phase of slip between 2.5 and about $0.5 \mathrm{MA}$, occurred when the Maacama fault was the northeastern fault of a right step between the Bennett Valley and Maacama faults, and included 
formation of the Little Sulphur Creek strike-slip basins. Axial deposition and paleoflow in the Little Sulphur Creek basins was parallel to the Maacama fault and basin deposition propagated northwestward in the direction of Maacama fault propagation. These relations, along with depositional facies are consistent with basin formation in conjunction with fault slip. The basin deposits extend for about $12 \mathrm{~km}$ along the Maacama fault, implying a slip rate of at least $5.4 \pm 0.6$ $\mathrm{mm} / \mathrm{yr}$ since 2.0 to $2.5 \mathrm{MA}$. These data give only a minimum slip rate because the basins have been uplifted and dissected, deposition in the basins has ceased and the basin deposits originally could have extended further to the northwest and southeast.

Oher data that provide offset criteria for the Maacama fault include offset volcanic and sedimentary units and obsidian clast provenance data. A distinctive stratigraphic section exposed in Franz Valley and in the area between Calistoga Road to the south and Porter Creek Road to the north, is truncated along the east side of the Maacama fault. A correlative section occurs along the southwest side of the fault along the lower Geysers Road northeast of Healdsburg. The base of this stratigraphic section includes fluvial gravel derived from the Tertiary volcanic section and Mesozoic basement rocks (Franciscan Complex, Great Valley Group and Coast Range ophiolite), and locally the gravel is deposited on Mesozoic basement. The basal gravel is overlain by the geochemically distinct 3.4 MA Putah tuff, which in turn is overlain by another geochemically distinct, 2.8 MA ash flow peculiar to the upper part of the thick siliceous volcanic ash section in Franz Valley. The known distribution of the Putah tuff, the total extent of the 2.5 MA and older Sonoma Volcanics across the Maacama fault zone, together with the apparent dextral displacement of the composite Franz Valley volcanic and sedimentary section, suggest as much as 22 to $24 \mathrm{~km}$ of right lateral separation along the fault, and a slip rate of about $10.4 \pm 1.6 \mathrm{~mm} / \mathrm{yr}$ since 2.0-2.5 MA.

Gravels, with obsidian clasts that were sourced from in-place obsidian in the Sonoma Volcanics of Annadel State Park and the Glass Mountain area of NapaValley, are apparently offset 13 to $18 \mathrm{~km}(15.5 \pm 2.5 \mathrm{~km})$ across the Maacama-Bennett Valley fault, yielding a slip rate of about $7.1 \pm 1.9 \mathrm{~mm} / \mathrm{yr}$ since $2.0-2.5 \mathrm{MA}$.

Lastly, the north side of Rincon Valley pull-apart basin adjoins the present south end of the Maacama fault for $5 \mathrm{~km}$ along the strike of the fault. Three kilometers of E-W extension and accompanying alluvial fan deposition has formed the Rincon Valley pull apart basin since the late early Pleistocene. The undeformed alluvial basin fill has been broadly assigned an age range of early to late Pleistocene ( 1.6 MA to $30 \mathrm{ka}$ ). Although it is likely that these deposits are middle Pleistocene in age or younger, no reliable age criteria are presently available to derive a defendable Pleistocene-Holocene slip rate for the Maacama fault. The various data sets thus suggest a slip rate for the Maacama fault in the range $\geq 5.4 \pm 0.6 \leq 10.4 \pm 1.6 \mathrm{~mm} / \mathrm{yr}$, with an average long term rate of about $8.95 \pm 1.1 \mathrm{~mm} / \mathrm{yr}$. The offset rate derived from obsidian clast provenance data suggests a slip rate of about $7.1 \pm 1.9 \mathrm{~mm} / \mathrm{yr}$ since $2.0-2.5 \mathrm{MA}$, which overlaps the average long term rate.

\section{Rodgers Creek-Healdsburg Fault Zone-}

Slip rates derived for the Rodgers Creek-Healdsburg fault zone differ from the Maacama-Bennett Valley fault zone in that the Rodgers Creek-Healdsburg fault zone appears to have been initiated more recently than the Maacama- Bennett Valley fault zone. The data on timing of faulting 
suggest that the Rodgers Creek-Healdsburg fault zone was initiated with formation of the Rincon Valley pull-apart basin, which is geomorphically more youthful than the Little Sulphur Creek basins and is filled with alluvial fan deposits which as indicated above, are not precisely dated, but considered to be younger than 1.6 Ma and older than about $30 \mathrm{ka}$ (Knudsen and others, 2000). Since younger basin fill is in discordant depositional contact with underlying Pliocene and early Pleistocene fluvial deposits, a conservative late early Pleistocene age is assigned to the oldest basin fill. The Rincon Valley pull-apart structure appears to have formed as a consequence of formation of several northwestward-stepping, north-trending tension faults (Riedel shears) along the southwest side of the Bennett Valley fault. The southwest side of the rhombic-shaped Rincon Valley extensional pull-apart is bounded by a 6-km length of the Rodgers Creek-Healdsburg fault zone, and this fault zone appears to have lengthened in conjunction with extensional widening of the Rincon Valley pull-apart. As with the Maacama fault, however, we cannot derive a Pleistocene-Holocene slip rate without a more well constrained estimate for the age of the oldest sediment fill of Rincon Valley (Santa Rosa) pullapart basin.

The other criteria for estimating offset across the Rodgers Creek-Healdsburg fault zone is the offset of Plio-Pleistocene fluvial gravels that exhibit southwestward paleoflow and contain geochemically distinct clasts of obsidian derived from sources in the Napa Valley (Glass Mountain) and Annadel State Park. The ${ }^{39} \mathrm{Ar} /{ }^{40} \mathrm{Ar}$ radiometric age of obsidian from the Glass Mountain area of Napa Valley is $2.78 \pm 0.02$ MA. Southwest of the Rodgers Creek-Healdsburg fault zone, gravels containing only Annadel sourced obsidian clasts and none derived from the Napa-Glass Mountain area, can be indirectly dated. These gravels are stratigraphically bracketed between the 4.83MA Lawlor tuff and the 6.3 MA Roblar tuff, and are therefore older than the Napa-Glass Mountain obsidian source. Elswhere, Annadel-derived obsidian clasts also are found in other widespread fluvial gravels, mixed with Napa-Glass Mountain-derived obsidian. These latter gravels, therefore, were deposited $\leq 2.78 \mathrm{MA}$., and largely overlie or interfinger with the uppermost Sonoma Volcanics. Because of the distribution of the obsidian clast lithofacies relative to the obsidian source areas, the presence of Annadel clasts alone and mixed with Napa-Glass Mountain-derived clasts is significant for deriving slip rates across the stepover faults. The minimum offset across the Rodgers Creek-Healdsburg fault zone required to restore the Annadel obsidian clast lithofacies to a position adjacent to the same lithofacies to the northeast, is about $10 \mathrm{~km}$. Alternatively, about $19 \mathrm{~km}$ of slip restores the Annadel-sourced gravel lithofacies to a position at the southeastern end of outcrops of the lithofacies northeast of the Rodgers CreekHealdsburg fault zone.

The displacements from the obsidian clast provenance data seem excessively high compared to the minimum rate derived from basin geometry. One possible reason for this may be a northwestward component of pre-faulting paleoflow southwest of the Healdsburg fault that could increase apparent displacement across the Rodgers Creek-Healdsburg fault zone. We also note that the model for development of the Rincon Valley (Santa Rosa) pull-apart basin seemingly makes it difficult to displace the Annadel-derived gravel lithofacies for any significant distance south of the mouth of Rincon Valley. The larger alternative displacement of $19 \mathrm{~km}$ derived from modeling of the obsidian clast data, therefore seems unlikely. Unless slip on the Rodgers CreekHealdsburg fault was initiated earlier than is assumed here, the alternative displacement model of $10 \mathrm{~km}$ of displacement since the early to middle Pleistocene from obsidian clast provenance data, is considered to be the most likely maximum slip for the Rodgers Creek-Healdsburg fault zone. Reliable long term Pleistocene-Holocene slip rates for the Rodgers Creek-Healdsburg fault await well constrained dates on the age of fill in the Rincon Valley (Santa Rosa) pullapart basin. 
Composite slip accommodated by Rodgers Creek-Maacama right-stepover-

The above estimates suggest that the aggregate fault displacement accommodated across the stepover region since $2.5 \mathrm{MA}$ ka is about $31 \pm 3 \mathrm{~km}$, indicating a long term slip rate of $12.6 \pm 1$ $\mathrm{mm} / \mathrm{yr}$. If all of this slip has been accommodated since $2 \mathrm{MA}$, then the aggregate slip rate has been $15.5 \pm 1.5 \mathrm{~mm} / \mathrm{yr}$.

\section{Locations and magnitudes of future earthquakes-}

Using the earthquake regression plots of Wells and Coppersmith (1994), and assuming that individual fault components of the right-releasing stepover are capable of rupturing as fault segments, earthquake moment magnitude capabilities of faults in the Rodgers Creek-Maacama fault stepover can be estimated. The relatively broad, diffuse distribution of seismicity beneath the stepover and the occurrence of fault mechanisms that include normal, right-lateral slip and thrusting, suggests that stress is accommodated beneath the stepover region on numerous faults of different orientations, and not exclusively on the primary through-going bounding strike slip faults (ie. the Rodgers Creek, Healdsburg, Bennett Valley and Maacama faults). Thus it is assumed that a moderate earthquake might nucleate anywhere within the $2400-2800 \mathrm{~km}^{3}$ of crust within the confines of the stepover, depending on the length and geometry of individual fault rupture segments.

The potential rupture lengths of both the Maacama-Bennett Valley and Rodgers CreekHealdsburg fault zones, based on the pull-apart area defined by the $155^{\circ}$ overlap of these principal deformation zones from the southeast side of the Rincon Valley pullapart, to Lytton and Geyserville, is about $40 \mathrm{~km}$ each. Based on the approximate depth limit for the majority of seismicity beneath the stepover region, a down-dip rupture limit of $10 \mathrm{~km}$ is also assumed for these faults, suggesting potential moment magnitudes $\left(\mathrm{M}_{\mathrm{m}}\right)$ of 6.6 for both the MaacamaBennett Valley and Rodgers Creek-Healdsburg faults. If either of these principal bounding fault segments were to rupture across the stepover along one of the NS-oriented faults bounding the Rincon Valley pullapart, or along the NS fault connecting the Healdsburg fault to the Maacama fault zone between Lytton and Geyserville, a potential rupture length of $50 \mathrm{~km}$ and $\mathrm{M}_{\mathrm{m}} 6.7$ events are implied. Similarly, a stepover earthquake rupturing southeastward from the Rincon Valley pullapart either along the Rodgers Creek or Bennett Valley faults to their juncture, implies a rupture length of 30-40 km and moment magnitudes of about $6.5-6.6$. If the entire $60-70 \mathrm{~km}$ length of the pull apart were to rupture along either the Rodgers Creek-Healdsburg or Bennett Valley-Maacama fault zones, then potential moment magnitudes of 6.7-6.8 are also implied.

If the Rodgers Creek-Healdsburg or Maacama-Bennett Valley fault zones rupture only along the $6 \mathrm{~km}$ long southern or $4 \mathrm{~km}$ long northern boundaries of the Rincon Valley pull-apart, then moment magnitudes of 5.8 and 5.7, respectively are predicted. The approximate $10 \mathrm{~km}-$ long, N-S oriented, normal faults along the east and west sides of Rincon Valley, if capable of independent earthquakes (as opposed to dominant secondary or triggered slip), might produce $\mathrm{M}_{\mathrm{m}} 6.0$ earthquakes. The $15 \mathrm{~km}$-long, N-NW-oriented cross fault connecting the Healdsburg and Maacama faults between Lytton and Geyserville at the northwest end of the stepover structure, might generate a $M_{m} 6.2$ earthquake, if that segment ruptured independently, rather than in concert with a rupture generated by an earthquake nucleated along the Healdsburg segment of the Rodgers Creek-Healdsburg fault zone.

In summary, the regression plots of Wells and Coppersmith predict seismic events within the stepover region with ranges of $\mathrm{M}_{\mathrm{m}} 6.8$ to 5.7 and less, depending on fault segment orientation 
and rupture dimensions along strike and down-dip. A larger magnitude earthquake event and associated surface rupture along the Rodgers Creek-Healdsburg or Maacama fault may be possible, but it is suggested that such an earthquake event would likely be nucleated outside the bounds of the pullapart structure defined here, possibly on the northern Hayward fault, or along the Maacama fault north of Geyserville.

\section{REFERENCES CITED}

Dooley, Tim, and McClay, Ken, 1997, Analog modeling of Pull-Apart Basins, Bulletin, American Association of Petroleum Geologists, v. 81, no.11, p.1804-1826

Knudsen, K.L., Sowers, J.M., Witter, R.C., Wentworth, C.M., and Helley, E.J., 2000, Preliminary maps of Quaternary deposits and liquefaction susceptibility, nine-county San Francisco Bay Region, California: A Digital Database: U.S. Geological Survey Open-file Report 00-444, Version 1.0

McLaughlin, R. J., and Nilsen, T. H., 1982, Neogene non-marine sedimentation in small pullapart basins of the San Andreas fault system, Sonoma County, California: Sedimentology. v. 29, p. 865-876

Nilsen, T.H. and McLaughlin, R.J., 1985, Comparison of tectonic framework and depositional patterns of the Hornelen Strike-slip basin of Norway and the Ridge and Little Sulphur Creek Strike-Slip basins of California: in Biddle, K.T., and Christie-Blick, editors, Strike Slip Deformation, basin Formation, and Sedimentation, Society of Economic Paleontologists and Mineralogists Special Paper no. 37, p. 79-103

Wells, D.L., and Coppersmith, K.J., 1994, New Empirical relationships among magnitude, rupture length, rupture width, rupture area and surface displacement, Bulletin, Seismological Society of America, v.84. n0.4, p.974-1002 
Figure 1. Shaded relief map showing location of the right-sidestep from the Rodgers Creek-Healdsburg fault zone to the Maacama-Bennett Valley Fault zone.

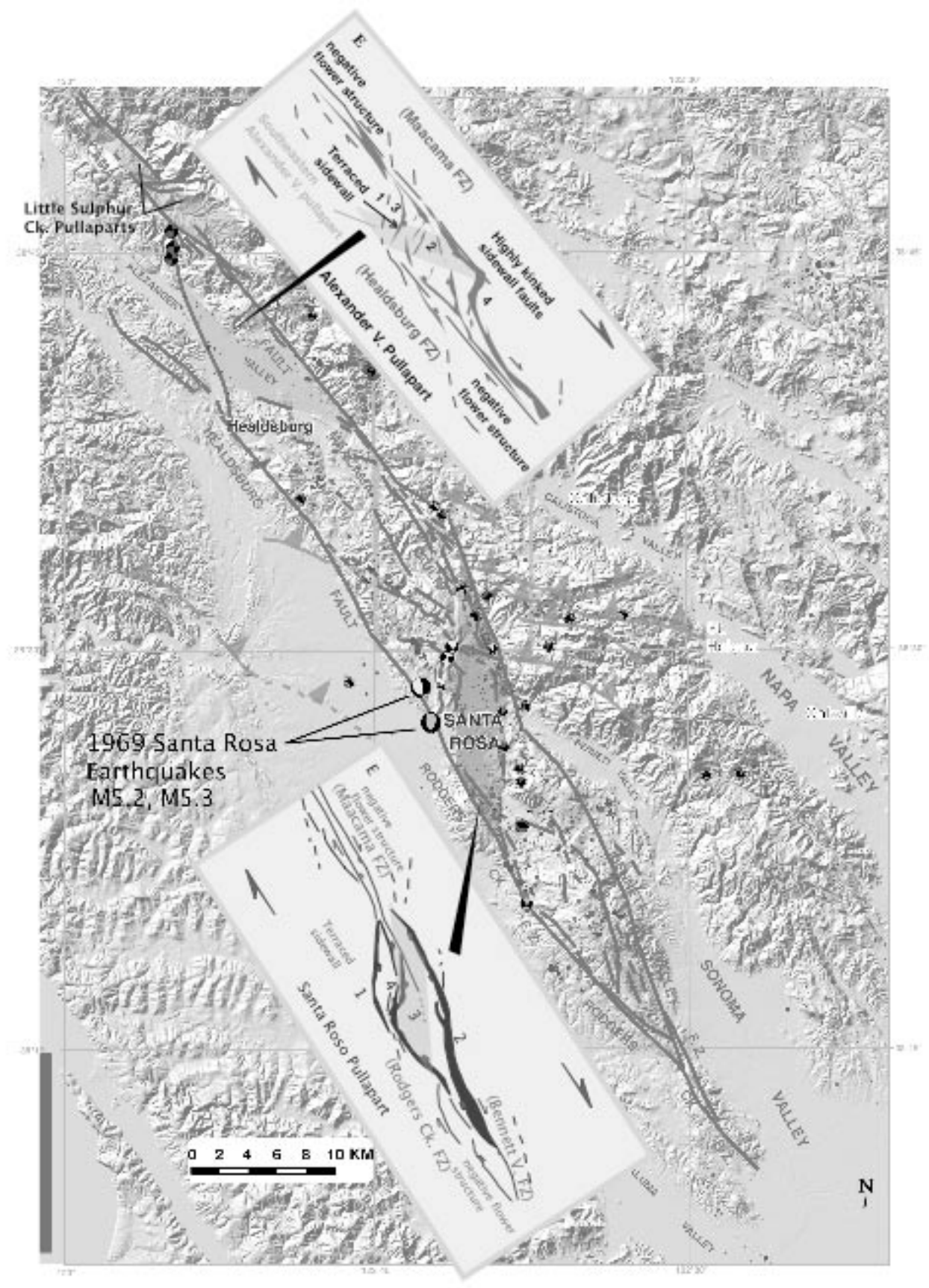



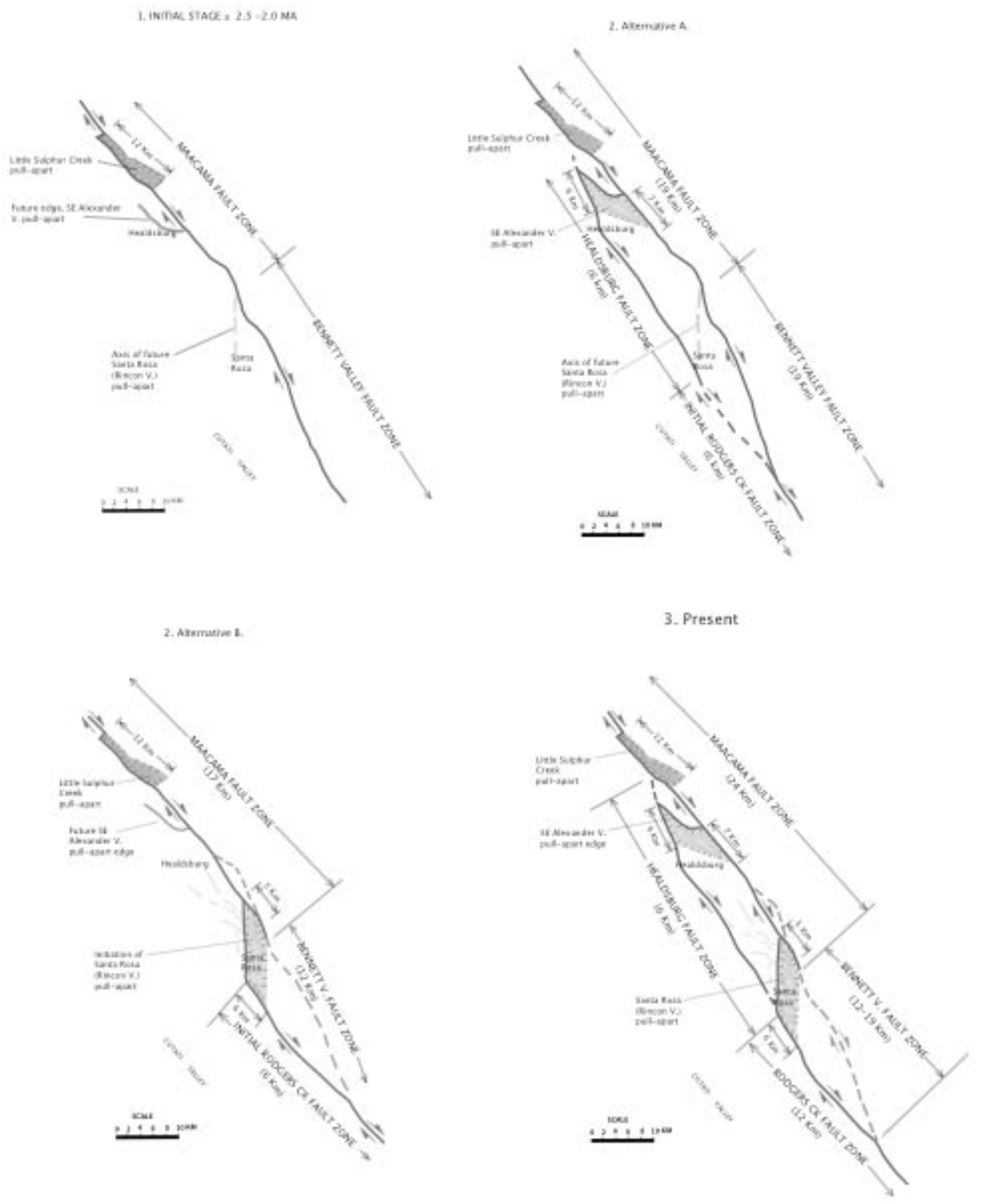

Figure 2. Model for evolution of extensional pullapart basins and generation of slip within the right-stepover between the Rodgers Creek-Healdsburg and the Maacama -Bennett Valley fault zones. 


\section{TOWARDS AN UPDATED 3D VELOCITY MODEL OF THE SAN FRANCISCO BAY AREA}

Walter D. Mooney, Jack Boatwright, Joe Fletcher, Shane Detweiler US Geological Survey, Menlo Park, CA

An updated community 3D seismic velocity model for northern California will represent a significant advancement in our abilities to conduct a number of geophysical studies. A model for Southern California has already been developed by SCEC and has proved invaluable to the research community. Such a model for northern California can be used for determining seismic event locations, finding source mechanisms, calculating sedimentary basin response to shaking, and in probabilistic hazard mapping and other quantitative estimates of earthquake risk.

The new model will be a 3D multi-parameter physical model of the crust, including faults and seismic/lithologic boundaries. The 3D model will extend from Salinas and Monterey north to the Geysers and east as far as Sacramento in order to include the coast ranges. To successfully produce such a model, we will first need to exploit existing seismic data to extract shearwave velocity information for use in model definition, and for the calculation of predicted ground motions for scenario earthquakes. We will also develop a new northern California 3D tomographic model that will serve as a background model for the deeper crust. As a next step, we will merge our more-detailed upper crustal knowledge with this background model in order to update the existing 3D seismic velocity model.

Our new model will be compatible with the SCEC model with the long-term goal of integrating the two models into one large, California model. In addition, the new model will include a suitable framework for the representation of the 3D model such that all users can easily access it through the Internet. We also plan to develop tools for model utilization, visualization, and to establish links to the database that is used to create the model. Other long-term goals include: 1) Developing enhanced tools for 3D model verification and modification, 3D wave propagation, and model visualization; 2) Continuing to acquire, process, and interpret high-resolution seismic and non-seismic data using EarthScope facilities and multi-institutional field programs, with a special emphasis on improving the modeling of the seismic response of the Santa Clara Valley; 3) Adopt multi-parameter inversion schemes that utilize multiple geophysical data sets; and 4) Implement high-speed computational approaches that permit model verification and modification in near-real time. 


\section{GEODETIC EFFORTS IN NORTHERN CALIFORNIA}

Jessica Murray (USGS), Mark Murray (UC Berkeley), and Roland Bürgmann (UC Berkeley)

Northern California currently has good geodetic coverage with survey-mode Global Positioning System (GPS) measurements. These include six transects across the San Francisco Bay Area, as well as measurements near Point Arena and covering Cape Mendocino and northward. Furthermore, several surveys which formerly did not extend eastward into the Great Valley now include sites reaching to the Sierra foothills. The Bay Area Regional Deformation (BARD) network has been operational for over a decade and now has close to 70 continuous GPS stations. Additionally, in recent years it has been shown that InSAR data may be successfully used to provide spatially dense observations of interseismic strain accumulation and fault creep, for example along the Hayward fault.

Major outcomes of research that has utilized these data include slip-rate estimates for Bay Area faults, a further characterization of the fault slip-rate distribution on the Hayward fault, and a better understanding of the interaction between Basin and Range extension and deformation north of the Mendocino triple junction in northern California. Topics of ongoing study include the extent and degree of geodetically observable convergence perpendicular to the San Andreas system, the spatio-temporal fault slip complexity at the Calaveras - San Andreas fault juncture near San Juan Bautista, and the seismic hazard on the Hayward fault. Furthermore, slip-rates inferred by various studies for northern California faults are difficult to compare directly because of the variety of analysis techniques employed. The Bay Area Velocity Unification (BAVU) project, newly undertaken by U.C. Berkeley, attempts to address this by analyzing all the Bay Area GPS data in a self-consistent manner using three dimensional block models to infer sliprates on major faults.

Several outstanding issues remain as Northern California prepares for the Plate Boundary Observatory (PBO). The PBOwill drastically improve continuous GPS (as well as strainmeter) density in northern California and fill most of the coverage gaps present in the BARD network. Exceptions include western California north of Cape Mendocino and the Coast Ranges south of Monterey (site of the Dec. 2003 San Simeon earthquake). As PBO sites come online, ongoing analysis of the steady stream of data will be necessary to identify any temporal variations in near real time. Another concern is the ability to rapidly deploy additional instruments for focused monitoring following a large earthquake. The USGS has the resources in terms of instruments and trained personnel to address this need, and planning for such an event is ongoing. Since PBO will provide broad continuous GPS coverage to most of Northern California, the role for survey-mode GPS will likely change in the coming years. Such measurements could provide increased spatial coverage to 1) monitor likely locales of blind thrust faults, 2) resolve the issue of convergence perpendicular to the San Andreas system, 3) improve resolution of fault slip-rates at depth, and 4) possibly distinguish between discrete faults versus evenly distributed shear across San Andreas system. An area of continued concern is the need for additional resources, both monetary and personnel, for maintenance of existing geodetic sites (creepmeters, strainmeters, and GPS) and telemetry.

$* * *$ 


\section{GEODETIC STUDIES OF THE NORTHERN SAN ANDREAS FAULT SYSTEM}

Mark H. Murray

Berkeley Seismological Laboratory, UC Berkeley, Berkeley, CA

We present results from several ongoing geodetic studies of the San Andreas fault system in northern California. These studies include:

1) Continuous GPS velocity and transient deformation. The Bay Area Regional Deformation (BARD) network of continuously operating GPS stations, a collaborative effort of U.C. Berkeley, the USGS, and many other institutions, now includes over 70 stations in northern California, particularly in the Parkfield, Long Valley caldera, and San Francisco Bay regions. Velocities from these stations constrain broadscale deformation patterns across northern California, including the motions of the Sierran-Great Valley block and San Andreas fault system. Several earthquakes, such as the 1998 San Juan Bautista and 2003 San Simeon events, have caused measurable transient deformation, and slow slip events have possibly been detected at San Juan Bautista and near the Cascadia subduction zone.

2) Broadband deformation measurements in the San Francisco Bay area. U.C. Berkeley, USGS, and Carnegie Institute of Washington are collaborating in the installation of 5 "Mini-PBO" broadband deformation stations along the San Andreas and northern Hayward faults. During July 2001 to August 2002, five boreholes were drilled and equipped with tensor strainmeters and 3-component L22 (velocity) seismometers. The strainmeters were recently developed by CIW and use 3 sensing volumes placed in an annulus with 120 degree angular separation, which allows the 3-component horizontal strain tensor to be determined. All of the stations include pore pressure sensors and 2component tiltmeters. Three of the stations now are equipped with Quanterra recording systems that provide $100-\mathrm{Hz}$ seismic and strainmeter data, and $1 \mathrm{~Hz}$ GPS data. The GPS antennas at these stations are mounted at the top of the borehole casings in an experimental approach to achieve stable compact monuments.

3) The northern California crustal motion map. We are conducting survey-mode GPS observations along the northern San Andreas, Ma'acama, and Bartlett Springs fault system. We are reoccupying profiles established in the early 1990's near Covelo, Ukiah, and Willets, and are establishing a new profile near Healdsburg. Most stations were previously observed in 1992-1995, so the new observations significantly improve the velocity estimates and derived strain accumulation (fault deep slip rates and locking depths) models. We are currently reoccupying stations between the Ukiah and USGS north Bay profiles to improve the deformation models near the Rodgers Creek fault. We are planning to combine these results with the BAVU observations in the SF Bay area to develop a crustal motion map consistent with the SCEC efforts in southern California.

4) Real-time GPS. Many of the BARD stations provide data in real-time using radio or framerelay telemetery. In collaboration with Doug Dreger and Ken Hudnut, we are developing methods to rapidly process the data to estimate coseismic displacements due to large earthquakes and to allow near real-time determination of finite-fault slip models and strong ground motions to augment earthquake notification. The geodetic observations can complement seismic data to provide a more robust determination of the fault orientation and extent, and the amount of slip during the rupture.

*** 


\section{DEEP ASEISMIC SLIP TRANSIENTS ON THE CENTRAL SAN ANDREAS FAULT}

Robert M. Nadeau and Thomas V. McEvilly

U.C. Berkeley Seismological Laboratory, UC Berkeley, Berkeley, CA

Along a $175 \mathrm{~km}$ segment of the central San Andreas fault, characteristically repeating microearthquakes $(\mathrm{M}<3.5)$ reveal patterns of extensive, large amplitude, long duration, quasiperiodic repetition (pulsing) of deep aseismic slip events. Pulsing occurs both in conjunction with and independent of transient slip from larger earthquakes. It extends to depths of $\sim 10$ to 11 $\mathrm{km}$ but may be deeper. In the northern half of the study area, pulse periodicity is on the order of 3 years and the occurrence of small to moderate quakes correlate with the onset periods of these pulses. The occurrence of Loma Prieta (to the immediate northwest of the study segment) also correlates with one of the pulse onset periods. The general pattern of pulsing in the northern region appears coherently timed over about 60 to $70 \mathrm{~km}$ of the SAF. However, localized modulations in the overall pulsing pattern occur and may be associated with locked-zone shielding effects (from Loma Prieta and the 1998 San Juan Bautista earthquakes) or from fault interaction effects near the juncture of the San Andreas and Calaveras faults. 


\section{A 2500-YEAR RECORD OF LARGE EARTHQUAKES ALONG THE NORTHERN SAN ANDREAS FAULT AT VEDANTA MARSH, OLEMA, CA}

Tina M. Niemi, Hongwei Zhang and Shari L. Generaux, University of Missouri - Kansas City, Department of Geosciences, 5110 Rockhill Rd., RHFH 420, Kansas City, MO 64110-2499, niemit@umkc.edu

Thomas Fumal, U.S. Geological Survey, 345 Middlefield Road, Menlo Park, CA

At Vedanta marsh, well-defined stratigraphy and abundant in-situ organic material allow the determination of the first long, high-resolution record for large earthquakes on the North Coast segment of the San Andrea fault. During the 1906 San Francisco earthquake, the ground ruptured along the northeastern edge of the Vedanta marsh where historical offset measurements near the site were about $5 \mathrm{~m}$. Five trenches were excavated across the faultalong with a 4-m deep Vshaped excavation. We exposed a $4 \mathrm{~m}$ section consisting of six major peat layers interbedded with fluvial gravel and marsh clay and silt: these marsh deposits interfinger eastward with colluvial gravels. A clear transition from predominantly fine-grained marsh deposits to coarse clastic sediment occurs at a depth of approximately $1 \mathrm{~m}$ and is probably caused by historical logging and land use changes in the watershed. Faulting occurs as 2-m-wide zone of upward-branching fault splays. We recognize evidence at least 12 large earthquakes using outward-splaying, upward fault terminations and fissure fills. The 1906 earthquake ruptured a portion of the upper gravel and a possible late 19th century road fill. Deformation of each of the three uppermost, laterally correlative peat layers that are exposed in all the trenches provide age constraints on the timing of four pre-1906 earthquakes. Earlier events were exposed only in the deep excavation. AMS radiocarbon dating of more than 70 samples of peat, macrofossils, and charcoal collected throughout the section indicate that the base of the exposed section is about $2500 \mathrm{yr}$ B.P. Recurrence intervals for the 7 youngest earthquakes are about 130 - 300 yrs. Several intervals as long as $500 \mathrm{yrs}$ in the older section suggest that the record exposed in the single deep excavation is incomplete.

$* * *$ 


\section{THE CALIFORNIA INTEGRATED SEISMIC NETWORK AND NORTHERN CALIFORNIA EARTHQUAKE MONITORING}

Dave Oppenheimer (US Geological Survey, Menlo Park, CA) and Lind Gee (Berkeley Seismographic Laboratory, UC Berkeley, Berkeley, CA)

The mission of the California Integrated Seismic Network (CISN) is to operate a reliable, modern, statewide system for earthquake monitoring, research, archiving, and distribution of information for the benefit of public safety, emergency response, and loss mitigation. Further, the CISN seeks to mitigate the impact of earthquakes by collecting, processing, and disseminating critical earthquake information in a timely way.

Five organizations have collaborated to form the CISN in order to further the goals of earthquake monitoring. The founding members of the CISN include: California Geological Survey Caltech, Seismological Laboratory, Berkeley Seismological Laboratory, USGS Menlo Park, and the USGS Pasadena. The California Governor's Office of Emergency Services is an ex-officio participant in the CISN. In addition to the core members, several organizations contribute data that enhances the capabilities of the CISN. Contributing members of the CISN include: University of California, Santa Barbara, University of California, San Diego, University of Nevada, Reno, University of Washington, California Department of Water Resources, Lawrence Livermore National Lab, and Pacific Gas and Electric.

To facilitate coordination of activities among institutions, the CISN has formed three management centers:

Southern California Management Center: Caltech/USGS Pasadena Northern California Management Center: UC Berkeley/USGS Menlo Park Engineering Management Center: California Geological Survey/USGS National Strong Motion Program

The Northern and Southern California Management Centers operate as twin earthquake processing centers. The Engineering Management Center has the lead responsibility for producing engineering data products.

The USGS Menlo Park and the UC Berkeley Seismological Laboratory are working improve the northern California monitoring system. A major effort to redesign software is underway, with the goal of taking advantage of the developments in southern California resulting from the TriNet project, as well as the software developed in Berkeley, Menlo Park and Golden. We hope to have a prototype of the system by mid summer 2004 .

More information on the CISN and its activities is available at www.cisn.org

$* * *$ 


\section{USGS COASTAL AND MARINE PROGRAM EARTHQUAKE HAZARD STUDIES IN NORTHERN CALIFORNIA}

Tom Parsons

U.S. Geological Survey, Menlo Park, CA

The Coastal and Marine Geology Program (CMG) has a small earthquake hazards component in northern California devoted primarily to numerical modeling. This represents a shift in focus from marine seismic data acquisition that was carried out in the region through most of the 1990's. Studies that complement Earthquake Hazards Program efforts are summarized.

In work conducted under the PEER program, new probabilistic techniques are developed in the field of structural reliability to develop fragility models for liquefaction triggering assessment. In addition, the relationship between shear wave velocity and ground failure potential is investigated, and shear wave velocity to depths of 20-30 meters is routinely profiled. A multi-layered multidirectional model is used to predict seismic shear displacements. Regional maps are in development. Contact: Rob Kayen (rkayen@usgs.gov)

Offshore earthquakes are relocated using the double difference method modified for the special case of events recorded by a one-sided network onshore, and special accommodations are made for the poor depth control on the initial catalog event locations. Methods are applied to the offshore San Gregorio fault zone. Contact: Stephanie Ross (sross@usgs.gov)

Hydrodynamic models are used to determine historic earthquake source parameters $(1906,1898)$ from observations of small tsunamis in San Francisco Bay. Contact: Eric Geist (egeist@usgs.gov)

Deep and shallow high-resolution seismic reflection and refraction data were extensively recorded in and around San Francisco Bay and, in combination with local earthquake tomography, have led to a variety of structural interpretations. CMG is leading an effort to secure and archive more than $250,000 \mathrm{~km}$ of oil industry seismic reflection data along the Pacific coast for general release to the academic community. Contact: Pat Hart (hart@usgs.gov)

Finite element modeling (FEM) is conducted to determine tectonic stressing rates and investigate the impact of large earthquakes like 1906 on present-day stress accumulation on faults. Predictions are made on the impact of viscoelasticity on stressing and fault slip rates, as well as the longterm effects of fault geometry on the regional stress field. Results of a recent 3-d FEM study for the Bay Region reproduces observed geologic slip rates on major faults and surface velocity vectors comparable to geodetic measurements Parsons (2002). Results also suggest that the 1906 stress shadow was erased by tectonic loading no later than 1980. An all-California FEM is in development that has variable rheology, crustal structure, topography, major fault zones, and will explore stressing effects of the current geodetically-determined strain field. (tparsons@usgs.gov).

-Seismic data archive:

http://geopubs.wr.usgs.gov/open-file/of00-494

-Compilation of 1991-1998 regional USGS CMG research:

http://geopubs.wr.usgs.gov/prof-paper/pp1658

-Download Tom Parsons research papers:

http://quake.wr.usgs.gov/research/deformation/modeling/refs/parsons_refs.htm]

$* * *$ 


\title{
EARTHQUAKE HAZARD INFORMATION FOR SMALL BUSINESSES AND MULTIFAMILY HOUSING WITH IMPLICATIONS FOR PUBLIC POLICY- SAN FRANCISCO BAY AREA
}

\author{
Jeanne Perkins \\ Association of Bay Area Governments (ABAG), Oakland, CA
}

With funding from the U.S. Geological Survey (USGS), ABAG developed the Home Quake Safety Toolkit, located at http://quake.abag.ca.gov/fixit. This site includes sections on both structural and nonstructural hazards and mitigation, as well as on family disaster plans. The structures section includes an innovative quiz to "self-assess" structural vulnerability based on shaking intensity and structural type. Structural retrofit resources include information on the retrofit process, lists of contractors, engineers, and home inspectors, success stories, and money. The nonstructural section includes a user-friendly quiz on causes of contents damage, ways to anchor contents, and chimney safety. In the third section, infrastructure disruptions and liquefaction are creatively explained using a quiz focusing on emergency planning. How-to planning resources focus on family emergency plans, emergency supplies, and natural gas safety. This toolkit was released in October 2003. ABAG is currently planning a Design Charette (with additional support from EERI) to identify public policy and design issues and potential solutions to the problem of soft-story multifamily residential buildings to be held in late winter or early spring of 2004.

ABAG is developing Tools for Businesses to Tame Disaster, also with USGS funding. This web site identifies several resources for small businesses that are multi-hazard in focus, particularly those dealing with speeding business recovery. Others tools focus on increasing employee and customer safety during earthquakes. Recovery tools focus on strategies to manage business disruption, plan for transportation and utility disruption, and plan for reoccupying buildings. Safety tools include information on bracing and anchoring building contents, natural gas safety, special hazardous materials issues, tort liability, and calculating benefits and costs of mitigation. The safety section will include innovative quizzes to "self-assess" vulnerability based on shaking intensity, structural type, and type of contents. The toolkit will be released in the late winter or early spring of 2004 .

$* * *$ 


\title{
MAPPING FAULT RUPTURE HAZARD FOR STIKE-SLIP EARTHQUAKES: A COOPERATIVE STUDY BETWEEN THE USGS, PEER, AND CGS
}

\author{
Mark PETERSEN ${ }^{1}$, Tianqing CAO ${ }^{2}$, Timothy DAWSON ${ }^{3}$, Arthur FRANKEL ${ }^{4}$, Chris WILLS $^{5}$, \\ and David SCHWARTZ 6 \\ ${ }^{1}$ U.S. Geological Survey, Golden, CO, USA. E-mail: mpetersen@usgs.gov \\ ${ }^{2}$ California Geological Survey, Sacramento, CA, USA. E-mail: tcao@consrv.ca.gov \\ ${ }^{3}$ U.S. Geological Survey, Menlo Park, CA, USA. E-mail: tedawson@usgs.gov \\ ${ }^{4}$ U.S. Geological Survey, Golden, CO, USA. E-mail: afrankel@usgs.gov \\ ${ }^{5}$ California Geological Survey, Sacramento, CA, USA. E-mail: cwills@consrv.ca.gov \\ ${ }^{6}$ U.S. Geological Survey, Menlo Park, CA, USA. E-mail: dschwartz@usgs.gov
}

Earthquake ruptures can cause significant damage to structures and lifelines located on or very near the causative fault. Recent surface fault ruptures have caused failure or near-failure on bridges (Japan, 1995; Taiwan, 2000; Turkey, 2000), pipelines (Alaska, 2002), and buildings (California, 1971). While it is essential to consider the effects of fault rupture displacements when designing new structures it may not be possible to relocate existing structures and lifelines that cross or are adjacent to active faults, and loss of these facilities can significantly impact society (loss of transportation routes, gas pipelines, electricity, dams, buildings, etc.). The goal of the project is the development of improved design-oriented conditional probability models needed for estimating fault rupture hazard within either a deterministic or probabilistic framework. This project is funded by the Pacific Earthquake Engineering Research Center (PEER) as part of the Lifelines Research Program and brings together researchers from the U.S. Geological Survey (USGS) and the California Geological Survey (CGS) in a cooperative effort to compile fault rupture and displacement data and use the data as the basis to develop probabilistic and deterministic surface rupture hazard relations for strike-slip earthquakes. These models will be used by Caltrans to help set priorities for retrofitting existing highway bridges and overpasses in California.

Our method follows the general probabilistic formulation developed by Youngs et al. (2003) for normal-fault displacements at the proposed Yucca Mountain nuclear waste repository in Nevada. Displacement and surface rupture data for nine global earthquakes were digitized and analyzed in a GIS framework. Regressions of these data were performed to obtain probability distribution functions for: (1) primary displacements along the fault, (2) distributed displacements normal to the fault, and (3) probability of generating distributed ruptures as a function of distance from the fault. In addition, we developed probability distributions of distance as a function of the quality of mapping based on geologic interpretations and applied global probabilities of surface rupture and maximum displacement for different earthquake magnitudes (Wells and Coppersmith, 1993, 1994). The probability density functions are combined into a final formula that calculates probabilistic fault rupture hazard at a site. The resulting hazard is presented as a displacement hazard curve, indicating the annual rate that a given displacement will be exceeded. From this calculation, hazard maps can be produced for a fault of interest. This mapping should be useful for evaluation of lifelines or structures that transect a fault zone.

This phase of the project is in the final stages and is currently refining and conducting sensitivity tests on both the data extracted from the GIS, as well as the computer code that calculates the probabilistic and deterministic hazard at a site of interest. These sensitivity tests take into consideration structure foundation size for different sizes of structure footprints, ranging from $200 \mathrm{~m}^{2}$ to $25 \mathrm{~m}^{2}$. 
The products of this project will appear in several forms. The basis for many of the probability density functions is the GIS data that has been compiled and digitized. This data will be released as an electronic publication with downloadable GIS shapefiles (Summer 2004). Additionally, either with the GIS data or as a separate document, we will include a detailed explanation of how the digitized data was analyzed and provide the results of our GIS analysis so that additional data can be added and incorporated into our analysis as they become available. Finally, a paper will be published in a peer-reviewed journal that describes the methodology used to calculate probabilistic fault rupture hazard, including examples for different faults within California.

\section{References}

Youngs, R. and 14 others, 2003, A method for probabilistic fault displacement hazard analysis (PFDHA), Earthquake Spectra, v 19, p 191-219. 


\section{STRESS EVOLUTION IN THE SF BAY REGION SINCE 1838}

Fred F. Pollitz

U.S. Geological Survey, Menlo Park, CA

Understanding of the behavior of plate boundary zones has progressed to the point where reasonably comprehensive physical models can predict their evolution. The San Andreas fault system in the San Francisco Bay Region (SFBR) is dominated by a few major faults whose behavior over about one earthquake cycle is fairly well understood. By combining the past history of large ruptures on SFBR faults with a recently proposed physical model of strain accumulation in the SFBR, we derive the evolution of regional stress from 1838 until the present. This effort depends on: (1) an existing compilation of the source properties of historic and contemporary SFBR earthquakes based on documented shaking, geodetic data, and seismic data (Bakun, 1999) and (2) a few key parameters of a simple regional viscoelastic coupling model constrained by recent GPS data (Pollitz and Nyst, 2003). Although uncertainties abound in the location, magnitude, and fault geometries of historic ruptures, and the physical model relies on gross simplifications, the resulting stress evolution model is sufficiently detailed to provide a useful window into the past stress history. In the framework of Coulomb failure stress we find that virtually all large earthquakes $(\mathrm{M}>=5.8$ prior to 1906 and $\mathrm{M}>=5.5$ after 1906) are consistent with triggering from previous earthquakes. These events systematically lie in zones of predicted stress concentration elevated 5-10 bars above the regional average. The SFBR is predicted to have emerged from the 1906 "shadow" in about 1980, consistent with the acceleration in regional seismicity at that time. The stress evolution model may be a reliable indicator of the most likely areas to experience $M>=5.5$ shocks in the future.

$* * *$ 


\title{
GEOPHYSICAL STUDIES ALONG THE HAYWARD FAULT AND THEIR IMPLICATIONS ON THE GEOMETRY AND SEGMENTATION OF THE FAULT, NORTHERN CALIFORNIA
}

\author{
D.A. Ponce, T.G. Hildenbrand, R.C. Jachens, R.W. Simpson, R.W. Graymer, \\ and C.M. Wentworth ${ }^{1}$ \\ ${ }^{1}$ U.S. Geological Survey, MS 989, 345 Middlefield Rd., Menlo Park, CA 94025
}

Recent geophysical studies combined with geology and seismicity data reveal the threedimensional geometry along the Hayward Fault. Distinct gravity and magnetic anomalies along the entire length of the Hayward Fault correlate to mapped mafic and ultramafic rocks. The most prominent of these anomalies reflects a 16-km long gabbro body near San Leandro. Inversion of gravity and magnetic data, constrained by physical property measurements, indicates that the San Leandro gabbro body is about $3 \mathrm{~km}$ wide, dips about $75^{\circ}$ northeast, and extends to a depth of at least $6 \mathrm{~km}$. One of the most striking results of the modeling, which was performed independently of seismicity data, is that accurately relocated seismicity (Waldhauser and Ellsworth, 2000), is concentrated along the western edge or stratigraphically lower bounding surface of the San Leandro gabbro. This suggests that the Hayward Fault probably reactivated or preferentially followed a pre-existing feature. Because earthquakes concentrate near the edge of the San Leandro gabbro but tend to avoid its interior, this massive igneous block may influence the distribution of stress.

Inter-relationships between gravity and magnetic anomalies, mafic and ultramafic rocks, structural trends, creep rates, and clusters of seismicity suggest that the Hayward Fault contains numerous fault-zone discontinuities, some of which may help define fault segments. One of the most prominent discontinuities is defined by the northern extent of the San Leandro gabbro, a gap in seismicity, a decrease in creep rate, a bend in the fault, and a locked or retarded patch. The approximate location of the great M6.8 1868 earthquake, near San Leandro (Bakun, 1999), combined with the fault-zone discontinuity associated with the San Leandro gabbro, suggests that the epicenter may have been located at or near a segment boundary and propagated bilaterally to both the northwest and southeast.

A three-dimensional geologic map of the Hayward Fault provides a view of the geology of the fault surface and the two resulting 'geologic maps', one for the east side and one for the west side, were compared with relocated double-difference seismicity data (Ellsworth et al., 2002). A correlation of seismicity to rock type is apparent when viewing the seismicity relative to the geologic map of the fault faces. In particular, far fewer earthquakes occur along the northern part of the fault where sheared Franciscan melange abuts the fault face, compared to the region to the south where more coherent Franciscan rocks and the Coast Range ophiolite are present. Moreover, clusters of earthquakes appear to correlate spatially with some of the contacts between Franciscan terranes as well as the Coast Range Ophiolite.

$* * *$ 


\section{PALEOSEISMOLOGY ALONG THE NORTHERN SAN ANDREAS AND MAACAMA FAULTS}

Carol Prentice, United States Geological Survey

In collaboration with: Robert Langridge, IGNS, New Zealand; Christopher J. Crosby, Arizona State University; Timothy Dawson, U.S. Geological Survey; Robert Sickler, Humboldt State University; Clark Fenton, URS Corporation; Tom Stephens, SHN, Eureka, CA

A new geologic slip-rate study along the North Coast section of the San Andreas fault near Fort Ross, California suggests the late Holocene slip rate is be lower than the $24+/-3 \mathrm{~mm} / \mathrm{yr}$ estimated by previous studies. Mill Gulch, a deeply incised stream, is offset $80-100 \mathrm{~m}$ across the San Andreas fault. We excavated trenches in the abandoned channel of Mill Gulch, northwest of the modern channel, and collected charcoal samples from pre- and post-abandonment sediments to estimate the age of this offset. Radiocarbon analyses of these samples provide minimum ages that range from 4290-4520 to 4890-5290 Cal. years BP, and a single maximum age of 5040-5320 Cal. years BP. These data yield a slip rate of $19+/-4 \mathrm{~mm} / \mathrm{yr}$, and a best estimate of $18+/-3 \mathrm{~mm} / \mathrm{yr}$ (Prentice et al., 2001). These data provide a better estimate than previous studies for the slip rate of the San Andreas fault north of the Golden Gate because the rate is averaged over a longer time interval, and the amount of offset is well known. Additional paleoseismic excavations at this site have provided evidence for three surface rupturing earthquakes. Analysis of radiocarbon samples will provide age constraints for these events.

Recent studies along the Maacama fault near Ukiah and Willits provide geologic slip rate estimates and age constraints for paleoearthquakes. Analysis of an offset terrace riser suggests a slip rate of about $9-13 \mathrm{~mm} / \mathrm{yr}$. Excavations across the fault provide evidence that suggests the most recent large earthquake occurred between 1520-1660AD (Sickler et. al., 1999; Sickler, 2003). Excavations across the Maacama fault at the Haehl Creek site near Willits yielded structural and stratigraphic data that suggest at least four and probably five faulting events during the (late?) Holocene (Fenton et al., 2002). Analysis of radiocarbon samples will provide age constraints for these events. Additional work planned for this summer is aimed at providing data for a late Holocene slip rate estimate.

$* * *$ 


\section{NORTHERN CALIFORNIA LIDAR PROJECT}

Carol Prentice, United States Geological Survey

In collaboration with: Christopher J. Crosby, U.S. Geological Survey; David J. Harding, NASA/ Goddard Space Flight Center; Ralph A. Haugerud, U.S. Geological Survey; Dorothy J. Merritts, Franklin and Marshall College; Tom Gardner, Trinity University; Rich D. Koehler, III, William Lettis \& Associates; John N. Baldwin, William Lettis \& Associates

Recent acquisition of airborne LiDAR (also known as ALSM) data covering approximately 418 square kilometers of coastal northern California provides a powerful new tool for mapping geomorphic features related to the San Andreas Fault and coastal uplift (Prentice et al., 2003). LIDAR data has been previously used in the Puget Lowland region of Washington to identify and map Holocene faults and uplifted shorelines concealed under dense vegetation (Haugerud et al., 2003; see http://pugetsoundlidar.org). Our effort represents the first use of LIDAR data for this purpose along the San Andreas Fault. This data set is the result of a collaborative effort between NASA Solid Earth and Natural Hazards Program, Goddard Space Flight Center, Stennis Space Center, USGS, and TerraPoint, LLC. The coverage extends from near Fort Ross, California, in Sonoma County, along the coast northward to the town of Mendocino, in Mendocino County, and extends inland between about 3-10 km. The survey area includes about $70 \mathrm{~km}$ of the northern San Andreas Fault under dense redwood forest, and Pleistocene coastal marine terraces both north and south of the fault along an approximately 120-km-long stretch of the coast. The average data density is two laser pulses per square meter, with up to four LIDAR returns per pulse. Returns are classified as ground or vegetation, allowing construction of both canopy-top and bare-earth DEMs with $1.8 \mathrm{~m}$ grid spacing. Vertical accuracy is better than $20 \mathrm{~cm}$ RMSE, confirmed by a network of 85 ground-control points established using high-precision GPS surveying. We are using hillshade images generated from the bare-earth DEMs to begin detailed mapping of geomorphic features associated with San Andreas Fault traces, such as scarps, offset streams, linear valleys, shutter ridges, and sag ponds. In addition, we are using these data in conjunction with field mapping and interpretation of conventional 1:12,000 and 1:6000 scale aerial photographs to map and correlate marine terraces to better understand rates of coastal uplift, and rates of strike-slip motion across the San Andreas Fault.

The information on Northern California Lidar dataset and some examples can be viewed online at:

http://quake.usgs.gov/research/geology/lidar

$* * *$ 


\section{LOW-FREQUENCY BOREHOLE STRAIN MONITORING IN NORTHERN CALIFORNIA: CURRENT STATUS AND OUTLOOK AS EARTHSCOPE (PBO) IS DEPLOYED}

Evelyn Roeloffs

U.S. Geological Survey, Vancouver, WA

Faults in the San Francisco Bay area are currently monitored by 5 borehole dilatometers, one Gladwin 3-component borehole strainmeter, and 5 mini-PBO 3-component borehole strainmeters. In preparation for the strainmeter deployments planned for PBO, we are currently involved in an assessment of the data from all of these instruments to evaluate some aspects of instrument performance as well as the influence of site characteristics on strainmeter performance.

Many strainmeters perform well, but data from some instruments have features that need to be understood better. For example, the atmospheric pressure response is larger for some instruments than others, and for other instruments unexpected steps appear in the data. Also, the influence of subsurface fluid pressure variations on the data is poorly understood. Automated data processing implemented as project staff declined did not permit these issues to be addressed thoroughly during the past few years.

The scientific rationale for collecting borehole strain data is elaborated in the PBO proposal. Briefly, borehole strainmeters are best suited to the detection of transient strain with durations ranging from hours to about one month, with time resolution of minutes (or better than 1 second, where high-frequency data is recorded). Regional earthquakes impose strain in this frequency range, so borehole strainmeters should be useful for measuring strain changes associated with Coulomb stress changes. Strainmeters also detect aseismic fault slip in the form of slow earthquakes.

Existing borehole strainmeters represent a series of technological improvements, and the project has been regarded partially as an instrument development research project. Additional work is needed to compile the archive of existing strain data, prepare it so that it is useable for research, and annotate it to account for instrumental artifacts.

PBO will deploy a significant number of additional borehole strainmeters throughout the tectonically active portions of northern California. The primary responsibility for maintenance and preliminary data processing for these instruments will reside with PBO.

An issue facing the USGS, however, is that our responsibility to issue hazards warnings would seem to require that we maintain a capability to perform authoritative interpretation of available borehole strain data. More generally, the Team needs to develop a state of readiness with respect to interpreting borehole strain, creep, and fluid pressure data. Data reviews on a regular basis (at least $2 x$ /year), maintenance of data archives by relevant university collaborators, and a plan for real- time interpretation are needed. These capabilities require additional staff.

The USGS should take credit for conceiving and operating the prototype arrays (Parkfield and Long Valley) that lead to PBO. In the spirit of pioneering technology that can later be deployed in larger numbers using MRE-type grants, the USGS could in the future collaborate with university engineers or national laboratories to facilitate development of strain-measurement technology that can operate at greater depths or higher temperatures, or in other types of challenging settings. One might imagine that 10 years in the future, boreholes several $\mathrm{km}$ deep will exist along other parts of the San Andreas system, and strain instrumentation for these boreholes will be available. 


\title{
STRAIN ACCUMULATION ACROSS THE COAST RANGES AT THE LATITUDE OF SAN FRANCISCO, 1994-2000
}

\author{
J. C. Savage, W. Gan ${ }^{1}$, W. H. Prescott ${ }^{2}$, and J. L. Svarc \\ U. S. Geological Survey, Menlo Park, California \\ ${ }^{1}$ Now at Institute of Geology, China Seismological Bureau, Beijing, China \\ ${ }^{2}$ Now at UNAVCO, Inc., Boulder, Colorado
}

66-monument geodetic array spanning the Coast Ranges near San Francisco has been surveyed more than 8 times by GPS between late 1993 and early 2001. The measured horizontal velocities of the monuments are well represented by uniform, right-lateral, simple shear parallel to $\mathrm{N} 29^{\circ} \mathrm{W}$. (The local strike of the San Andreas Fault is $\sim \mathrm{N} 34^{\circ} \mathrm{W}$.) The observed areal dilatation rate of $6.9 \pm 10.0$ nstrain yr-1 (quoted uncertainty is one standard deviation and extension is reckoned positive) is not significantly different from zero, which implies that the observed strain accumulation could be released by strike-slip faulting alone. Our results are consistent with the slip rates assigned by the Working Group on California Earthquake Probabilities [2003] to the principal faults (San Gregorio, San Andreas, Hayward-Rodgers Cr., Calaveras-Concord-Green Valley, and Greenville faults) cutting across the GPS array. The vector sum of those slip rates is $39.8 \pm 2.6 \mathrm{~mm}$ yr- $1 \mathrm{~N} 29.8^{\circ} \mathrm{W} \pm 2.8^{\circ}$, whereas the motion across the GPS array (breadth $120 \mathrm{~km}$ ) inferred from the uniform strain rate approximation is $38.7 \pm 1.2 \mathrm{~mm}$ yr- $1 \mathrm{~N} 29.0^{\circ} \mathrm{W} \pm 0.9^{\circ}$ rightlateral shear and $0.4 \pm 0.9 \mathrm{~mm}$ yr $-1 \mathrm{~N} 61^{\circ} \mathrm{E} \pm 0.9^{\circ}$ extension. We interpret the near coincidence of these rates and the absence of significant accumulation of areal dilatation to imply that rightlateral slip on the principal faults can release the accumulating strain; major strain release on reverse faults subparallel to the San Andreas Fault within the Coast Ranges is not required. 


\title{
IMPLEMENTING THE STRUCTURAL MONITORING PROGRAM OF THE ADVANCED NATIONAL SEISMIC SYSTEM
}

\author{
William U. Savage, U.S. Geological Survey, Menlo Park, CA
}

The 1999 authorization by the US Congress of the USGS-led Advanced National Seismic System (ANSS) called for the installation of 3000 structural monitoring instruments in addition to 3000 urban ground response instruments and about 1000 instruments to upgrade regional and national seismic networks. During the first four years of limited funding of ANSS, focus was placed on installing high-quality strong-motion instruments to measure shaking levels and prepare ShakeMaps in the San Francisco Bay Area and Seattle, Anchorage, Reno, and Salt Lake City, comparable to the density of instrumentation in the greater Los Angeles are in Southern California. The focus of ANSS is now shifting (in FY2004) to bring structural monitoring into balance with the other components of ANSS. The planned full ANSS funding for structural monitoring will enable instrumentation of 200 to 400 structures at 20 to 50 data channels per structure.

The primary objective for ANSS structural instrumentation is to obtain structural response measurements during earthquakes that can be used to improve predictive models of representative building types and other typical structures, and thus refine design and retrofit codes and practices, and calibrate post-earthquake damage evaluations. Attendant objectives include improving data quality and reduceing overall costs for instrumentation, and using real-time monitoring for response and recovery following earthquakes and other hazard events.

Each structure to be instrumented is selected to assure that: (1) recorded data will address welldefined, high-priority structural engineering needs; (2) the structure is representative of a large number of structures exposed to earthquake hazards; (3) the structure is located in an area that has a high probability of being shaken at a level sufficient to provide the desired structural response data; and (4) there is access to the structure for post-earthquake inspections and analysis. Ongoing extensive involvement of practicing and research earthquake engineers and leading organizations such as the NSF Centers and the NEES Consortium will identify priority needs for structural response data, and recommend specific instrumentation projects.

The current inventory of strong-motion stations in northern California includes instrumentation located at both ground (reference and freefield) and structural monitoring (primarily building, dam, and bridge) stations, which are operated primarily by the U.S. Geological Survey (USGS) and the California Geological Survey (CGS).

The CGS operates more than 900 strong-motion stations throughout northern and southern California, which include instrumentation located at approximately 650 ground sites, 170 buildings, 20 dams, and 60 bridges (see http://www.consrv.ca.gov/cgs/smip/station.htm).

The USGS National Strong-Motion Program (NSMP) operates 160 strong-motion stations in northern California: instrumentation includes approximately 200 digital and 25 analog accelerographs (see http://nsmp.wr.usgs.gov/station_list/nsmn_stations_state.htm1). Approximately 60 percent of the digital accelerographs have communication capabilities: one half of the recorders stream real-time data to the Northern Cailfornia Seismic Network in Menlo Park; and one half maintain dialup communication with the NSMP Data Center in Menlo Park. The NSMP stations include 13 extensively buildings, 1 freeway interchange structure, 1 landslide array, and 12 dams. The USGS operates ANSS instrumentation at nearly 70 ground motion stations and 2 buildings in northern California. 


\section{APPLYING MASSIVE WAVEFORM CROSS CORRELATION AND DOUBLE DIFFERENCE LOCATION TO NORTHERN CALIFORNIA AND CHINA}

Schaff, D. P., Waldhauser, F., and Richards, P. G.

Lamont-Doherty Earth Observatory, Columbia University

In recent years substantial advances in earthquake location have realized one to two orders of magnitude improvement over seismically broad areas due to the complementary benefits of waveform cross correlation and double-difference (DD) relative location in reducing both measurement and velocity model errors respectively. We report on results from applying these techniques on a massive scale to locally recorded seismic data across all of Northern California and to regional and teleseismic data in China.

We are in the process of performing 2.5 billion correlation measurements on 280,000 events in Northern California from 1984 to present. The waveforms comprise the entire digital archive at the NCEDC recorded by 900 short period vertical component stations totaling $225 \mathrm{~GB}$ of data. We use a correlation detector instead of a correlation function to allow lags greater than $1 / 2$ of the window length (typically 1 to 2 secs) to be searched. At station JST, which includes 35,000 events from Bay area faults such as the Hayward, the Calaveras, and the San Andreas faults, $40 \%$ of the events have at least one other event with cross-correlation coefficients (CC) greater than 0.9 (62\% for CC > $0.8,77 \%$ for $\mathrm{CC}>0.7$ ). These percentages of similar events are surprisingly high, but they include known areas of repeating events on the Calaveras and San Andreas faults. For a station in Long Valley Caldera recording 72,000 events, the distribution is $18 \%$ for $\mathrm{CC}>0.9,43 \%$ for $\mathrm{CC}>0.8$, and $67 \%$ for $\mathrm{CC}>0.7$. A station including 20,000 events in the different tectonic settings of Mendocino Triple Junction and Geysers Geothermal Fields has $16 \%$ of the events with $\mathrm{CC}>0.9$ with at least one other event, $32 \%$ with CC $>0.8$, and $49 \%$ with CC $>0.7$. The lower numbers of correlated events observed at the latter two stations most likely reflect the different faulting processes that take place in these areas, compared to the (mostly) strike-slip events recorded at JST. To improve the accuracy of inter-event distances from which we determine pairs of events for correlation measurements we have relocated about 240,000 events using the double-difference method together with about 5 million NCSN P-phase picks. The mean shift between routine NCSN locations and DD relocations is about 300 and $500 \mathrm{~m}$ in the horizontal and vertical directions, respectively. The relocated seismicity shows a substantially increased level of detail across most of the Northern California region, which can be significantly enhanced by incorporating the cross correlation differential time measurements, once they are available.

In China, we applied cross correlation methods to seismograms recorded at regional and teleseismic distances from $\sim 14,000$ earthquakes and explosions, to measure relative arrival times to an accuracy of $\sim 0.01 \mathrm{~s}$, obtaining location precision around a few $100 \mathrm{~m}$--- approximately a hundredfold improvement over current methods. From the results it is discovered about $10 \%$ of earthquakes in and near China, reported for the period 1985 to 2000 with $M>=3$, are repeat events generating essentially the same signals from sources each of which cannot be more than about $1 \mathrm{~km}$ from another event.

$* * *$ 


\title{
THE BAY AREA PALEOEARTHQUAKE EXPERIMENT (BAPEX) AND THE BAY AREA EARTHQUAKE CYCLE
}

\author{
David P. Schwartz, U. S. Geological Survey, Menlo Park, CA for BAPEX* \\ http://quake.usgs.gov/research/paleoseismoloty/bapex/
}

The Bay Area Paleoearthquake Experiment (BAPEX) was initiated in late FY98 as a focused and coordinated effort between USGS geologists and the broad community of paleoseismologists and earthquake geologists funded through a USGS/PG\&E CRADA and the NEHRP external program. Its goal is to systematically develop information on the dates of past earthquakes and slip rates on the major San Francisco Bay Region (SFBR) faults for the past 2000 years, which is an interval spanning four to five earthquake cycles (the historical record only spans part of one cycle). To date investigations have been made at 47 sites (Figure 1); some of these represent the continuation of previous studies but the majority are at new locations. About half have yielded some type of important new information such as timing of the most recent large event (MRE), the first long paleoearthquake chronologies in the region, slip rates, or fundamental insights into the coseismic behavior of creeping faults.

A major BAPEX contribution is dating that is increasing the understanding of the Bay Area earthquake cycle. Stress changes produced by the 1906 San Francisco earthquake had a profound effect on Bay Area seismicity, dramatically reducing it in the 20th century. Whether the SFBR is still within, is just emerging from it, or is out of the 1906 stress shadow is an issue of strong debate with important implications for earthquake mechanics and seismic hazards. Historically the SFBR has not experienced one complete earthquake cycle--the interval immediately following, then leading up to and repeating, a 1906-type (multi-segment rupture, M7.9) San Andreas event. The historical record of earthquake occurrence in the SFBR appears to be complete at about M5.5 back to 1850 (Bakun, 1999), which is less than half a cycle. For large events (qualitatively placed at M,,7) Toppozada and Borchardt (1998) suggest the record is complete back to 1776, which may represent about half a cycle. During this period only the southern Hayward fault (1868) and the San Andreas fault (1838?, 1906) have produced their expected large events. New paleoseismic data, primarily a chronology of the most recent large event (MRE), or penultimate event for faults with historical earthquakes, now provide a more complete view of the most recent pre-1906 SFBR earthquake cycle.

The San Andreas (SA), northern Hayward (HN), southern Hayward (HS), and Rodgers Creek (RC) provide clear paleoseismic evidence for large events post-1600 AD. The San Gregorio (SG) most probably produced a large earthquake after this date. Observations also suggest surface rupturing events on the northern Calaveras and Green Valley faults during this interval. The timing of the MREs and penultimate events, in years AD, follows. The age ranges are 2sigma radiocarbon intervals; the dates in parentheses are 1-sigma. Ages are: a) SA 1600-1670 (1630-1660), NH 1640-1776 (1635-1776); SH 1635-1776 (1685-1676); RC 1690-1776 (17301776); San Gregorio 1270-1776 but likely 1640-1776 (1685-1776); and NC 1670-1830. Based on present radiocarbon dating, the $\mathrm{NH} / \mathrm{SH} / \mathrm{RC} / \mathrm{SG} / \mathrm{NC}$ sequence likely occurred subsequent to the penultimate large San Andreas event. Although offset data, which reflect M, are limited, observations suggest that the penultimate large SA event ruptured essentially the same fault length as 1906 (Schwartz et al, 1998). In addition, measured point-specific slip (RC, 1.8-2.3m; $\mathrm{SG}, 3.5-5 \mathrm{~m})$ and modeled average slip $(\mathrm{SH}, 1.9 \mathrm{~m})$ for the MREs indicate large magnitudes for these paleoearthquakes. 
A major observation from these paleoseismic data is that during a maximum interval of 176 years (1600 to 1776 at 2-sigma)) significant seismic moment was released in the SFBR by large $(M, 6.7)$ surface-faulting earthquakes on the major regional faults. Figure 2 is a schematic representation of the timing of large Bay Area paleoearthquakes and historical earthquakes. Paleoearthquake "dates" are represented here simply as the midpoint of the 1-sigma radiocarbon age range (horizontal lines) for each event and the actual order could differ. However, even when the individual dates are shifted within the dating uncertainties it is clear that the major regional faults failed in a multi-decadal period from the late 1600s to early-mid 1700s (with the possibility of additional SA North Coast and southern Santa Cruz mountains events during this time). As a result, by the beginning of the historical period the SFBR had released most of its strain and there appears to be a quiescent period (for large events) from at least then until 1838. Depending on the actual date of the penultimate large San Andreas earthquake, the data are permissive for a regional stress shadow, similar to 1906 , to have followed it in the 1600 s.

Longer paleoearthquake chronologies with more precise event dating in the SFBR provide the exciting potential for defining regional earthquake cycles, modeling long-term fault interactions, evaluating the coefficient of variation for recurrence times, and improving recurrence estimates for hazard and probability calculations.

*Organizations contributing to BAPEX: Cotton-Shires Associates, Epigene International, Geomatrix Consultants, Harlan Tate Associates, Lawrence Livermore National Laboratory, William Lettis and Associates, Nolan Associates, PG\&E, Piedmont Geosciences, San Diego State University, San Francisco State University, San Jose State University, USGS, UC Berkeley; University of Missouri, University of Oregon, UC San Diego, Woodward-Clyde (URS) Consultants, P. Williams Consultants 


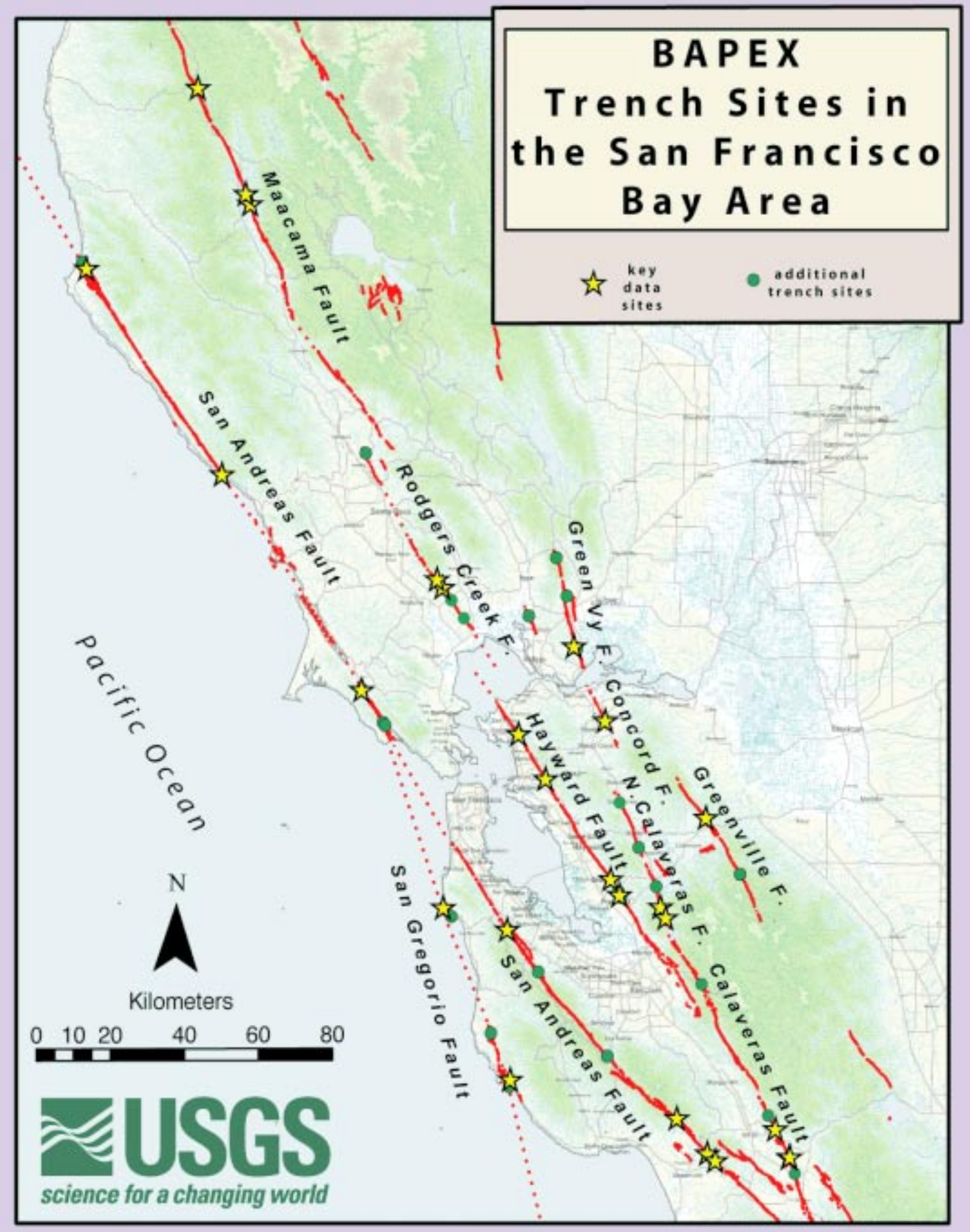

Figure 1. BAPEX trench site locations in the San Francisco Bay Area 


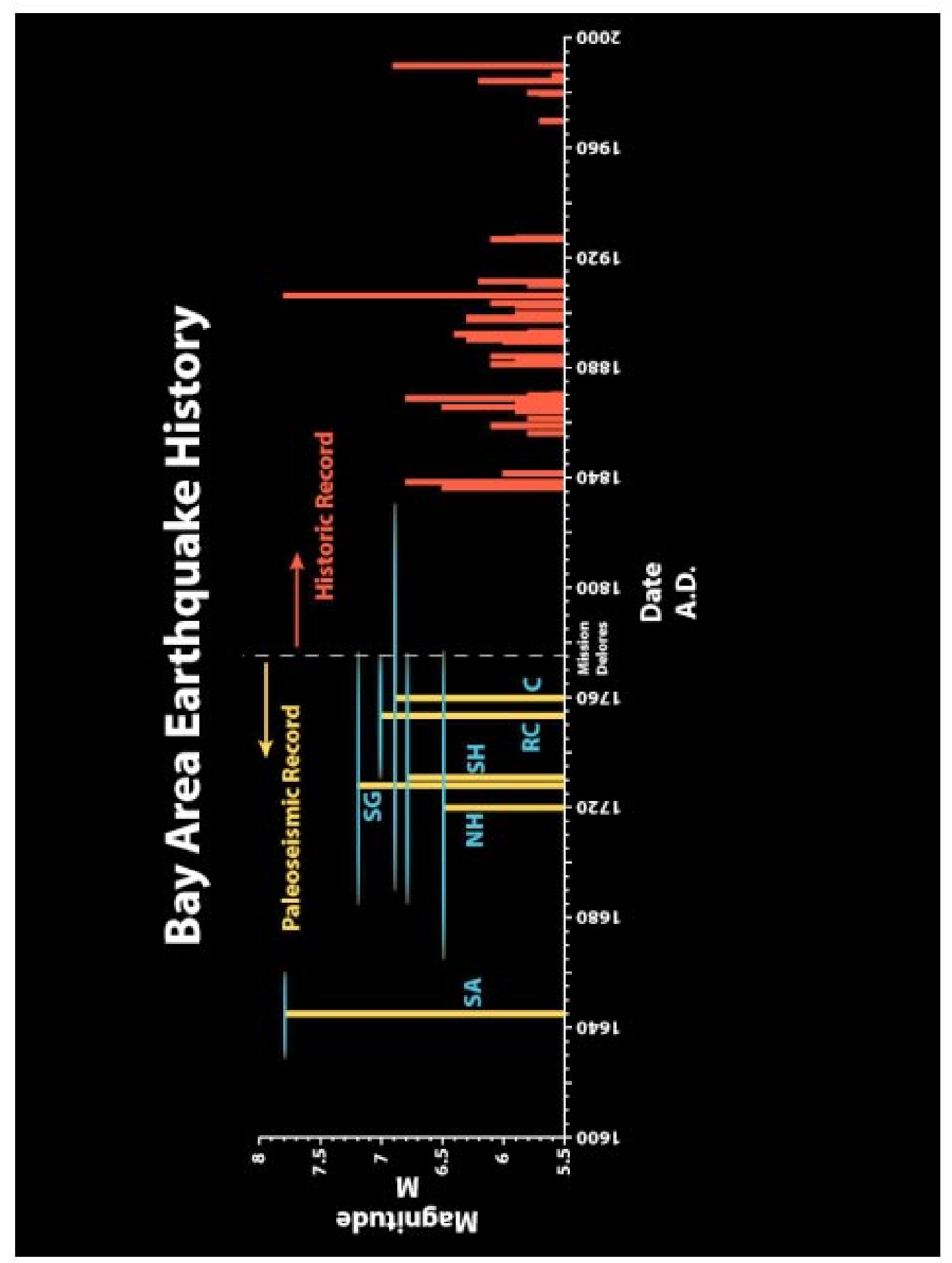

Figure 2. Timing of large Bay Area paleoearthquakes and historical earthquakes. Paleoearthquake "dates" are represented here as the midpoint of the one-sigma radiocarbon age range (horizontal lines) for the event. The magnitude of each paleo earthquake is the mean magnitude for that fault from the 2002 Bay Area Working Group on Earthquake Probability report.

$* * *$ 


\title{
CLOSING THE GAP BETWEEN ON AND OFFSHORE PALEOSEISMIC RECORDS IN THE LAKE TAHOE BASIN
}

\author{
Gordon Seitz, San Diego State University, San Diego, CA \\ Graham Kent, University of California, San Diego, Scripps, CA
}

The severity of seismic hazard within the Lake Tahoe basin has been largely under-appreciated due in large part to the lake coverage which delayed the recognition of active faults. Recent geologic and geodetic studies clearly show significant Holocene activity on three major faults. However, what is not known is the recurrence behavior of these faults, the associated magnitude and the timing of the most recent event.

The deformation across three active faults, within the Lake Tahoe basin, totaling $80 \mathrm{~km}$ in length, has been characterized using a novel combination of swath bathemetry, high resolution seismic CHIRP, airborne laser altimetry imagery, deep-water $(\sim 500 \mathrm{~m})$ and shallow-water $(\sim 25 \mathrm{~m})$ AMS C-14 dated sediment cores. This has resulted in the most robust sliprate estimate for Lake Tahoe faults.

For example, we have collected a striking sub-meter resolution seismic image of the Stateline fault expressed by a $10 \mathrm{~m}$ high surface scarp, located at a water depth of $500 \mathrm{~m}$. Cumulative fault slip rates and extension rates across the lake basin encompassing three faults, including the Stateline fault, were estimated by correlating displacements of two strainmarkers 1) the 9-15 m of vertical displacement across the entire lake, of a submerged shoreline, and 2) an approximately $23 \mathrm{~m}$ displacement of a seismically clearly identifiable stratigraphic horizon, the McKinney Bay slide, across the Stateline fault. A C-14 dated sediment core has allowed an age estimate of the McKinney Bay slide deposit. Considering that the basin-wide submerged shoreline strainmarker is displaced about half the amount of the single-fault displacement McKinney Bay slide deposits, allows a corresponding maximum age estimate. A C-14 dated shallow-water core of the submerged shoreline further constrains the age to as young as $12 \mathrm{ka}$. By assuming constant fault sliprates and fault dips of 60 degrees we estimate a minimum extension rate, across the entire lake basin encompassing three faults, of $0.5 \mathrm{~mm} / \mathrm{yr} \pm 0.35 \mathrm{~mm} / \mathrm{yr}$. Given the dimensions of the Lake Tahoe faults and typical displacements, this strain is most likely released in large seiche producing M7 range earthquakes with a recurrence time on the order of a few thousand years.

Most of the active Lake Tahoe faults are located in the deeper portions of the lake, however our target, the Incline Village fault clearly extends onshore. Of the three the three major faults that we have identified as active, the easternmost Incline Village fault creates a spectacular on and offshore scarp in late Pleistocene to Holocene age deposits. This presents a unique opportunity to conduct an onshore trenching study in close proximity to a detailed offshore highresolution seismic $3 \mathrm{~d}$ grid with associated sediment coring. Conducting this study in for Lake Tahoe relatively shallow water (15-25m) will also help develop the methodology for offshore paleoseismic investigations in other locations. We anticipate that results from this study may provide the first on fault evidence of past earthquake occurrence and associated magnitude for the Lake Tahoe Basin. Additionally, these results will provide a test for the increasingly cited "earthquake induced turbidite model" being applied here and elsewhere.

$* * *$ 


\title{
STRUCTURES IN THE HAYWARD AND CALAVERAS FAULT ZONES INFERRED FROM RELOCATED SEISMICITY
}

\author{
Robert W. Simpson, Russell W. Graymer, Robert C. Jachens, David A. Ponce, Carl M. Wentworth \\ U.S. Geological Survey, 345 Middlefield Rd., Menlo Park, CA
}

Sixteen years of earthquakes recorded by the Northern California Seismic Net (NCSN) between 1984-2000 and relocated using the Double-Difference technique (Ellsworth and others, Eos, 2000) reveal a number of intriguing structures within the Hayward and Calaveras fault zones and a complex relationship between the main fault surfaces and secondary oblique or reverse faults. As suggested by Waldhauser and Ellsworth (2002) and Manaker and Michael (2003), the central Calaveras fault appears to connect to the Hayward fault through a volume bounded on the north by the Mission seismicity trend. As defined by seismicity below $6 \mathrm{~km}$ depth, the connection appears quite simple, involving several straight, near-vertical segments forming a restraining bend along the Mission seismicity trend. Above $6 \mathrm{~km}$ the connection is complex and not well-defined by seismicity. At the Earth's surface, the mapped creeping trace of the southern Hayward fault deviates from the eastward diverging seismicity along the Mission trend, suggesting that the fault dips to the east in this vicinity to connect with the deeper seismicity. The mapped active central Calaveras fault trace is not very linear, has several strands in many places, and deviates by $2-3 \mathrm{~km}$ from the upward projection of a planar fault surface at depth, beautifully delineated by seismicity. The mapped surface traces of the two faults do not connect, but run subparallel about $5 \mathrm{~km}$ apart for $25 \mathrm{~km}$. The area of overlap is characterized by mapped reverse and oblique faults. At one location in the overlap region, seismicity suggests a dipping fault that appears to cut and offset horizontally a near-vertical Calaveras fault plane, raising the interesting possibility that seismogenic asperities are being created as the strike-slip and reverse/oblique systems interact. Intersections of this sort between two active fault systems might well explain the linear streaks of repeating microearthquakes that have been noted in a number of studies. One unanswered question is how such complex, interacting fault systems evolve in time, and whether the active creation of asperities might affect the temporal behavior of earthquakes on a fault, as may have occurred if the 1983 Coalinga event led to changes in the geometry of the San Andreas fault surface near Parkfield.

$* * *$ 


\title{
EVALUATING THE REPEATABILITY OF LATERAL SPREADING NEAR WATSONVILLE, CALIFORNIA
}

\author{
Stephen C Thompson, Robert C. Witter, and William R. Lettis \\ William Lettis \& Associates, Inc. \\ 1777 Botelho Dr., Suite 262 \\ Walnut Creek, CA 94596 \\ 925-256-6070, -6076(FAX) \\ thompson@lettis.com
}

Exploratory trenches across the late Holocene floodplains of the Pajaro River, northern California, revealed evidence for liquefaction-induced lateral spreading. This first-year feasibility study, designed to evaluate the repeatability and, therefore, predictability of lateral spreading associated with liquefaction, established an example of recurring sand injection and lateral spreading along a stratigraphic unconformity within the Pajaro River floodplain near Watsonville. We excavated two trenches across a lateral spread formed after the 1989 Loma Prieta earthquake on the Pajaro River floodplain near Watsonville, in an area identified and studied by US Geological Survey geologists and geotechnical engineers after that event (Holtzer et al., 1994; Bennett and Tinsley, 1995). In addition to liquefaction-related features produced in 1989, the trench walls revealed evidence for 2 to 4 prior lateral spread failures and associated liquefied sand bodies. The site likely included failure from the 1906 M7.8 San Francisco and penultimate San Francisco-type events. The repeated spreading occurred along a $\sim 1-\mathrm{m}$-wide zone that coincides with a buttress unconformity between mid Holocene floodplain deposits and late Holocene to historic fluvial deposits of an aggraded inset river terrace of the Pajaro River (Dupré and Tinsley, 1980). Small $(<1 \mathrm{~cm})$ vertical offsets several meters inboard of the main lateral spread zone are associated with minor ground cracking observed after the 1989 event. Although it is permissible that an earlier lateral spread event produced some of the minor normal fault displacements, the small magnitude of these failures relative to the massive failure along the main lateral spread zone indicates that this secondary deformation is minor and that the main zone of failure occurs in a repeatable fashion. By evaluating geologic evidence for repeated lateral spreading, our research is a first step towards testing the premise that the location and magnitude of lateral spreading is a predictable phenomenon subject to epistemic uncertainty and does not occur randomly within an area of high liquefaction susceptibility. The consequence of this study will be whether or not, in certain geologic environments, we can treat lateral spreads similar to fault ruptures such that specific locations, magnitudes, and orientations can be predicted for evaluation of impact to the built environment (i.e., lifelines, buildings).

NEHRP Award \# 03HQGR0075

$* * *$ 


\section{IMPROVING EARTHQUAKE LOCATIONS AND VELOCITY MODELS IN NORTHERN CALIFORNIA}

Clifford Thurber and Wen-xuan Du

University of Wisconsin-Madison

We are beginning a new project aimed at improving earthquake locations and velocity models in northern California. We will apply improved waveform alignment and seismic tomography techniques to available seismic data in order to develop regional three-dimensional seismic velocity models for targeted regions of northern California. The techniques we will apply have recently been developed by our research group, and involve (1) the use of the bispectrum method to verify the quality of waveform cross-correlation (WCC) differential arrival times for pairs of similar waveforms, and (2) the use of differential arrival times (catalog and WCC) in the simultaneous inversion for hypocenters and velocity structure, which we term double-difference tomography. Our work will also contribute to improving knowledge of the geometry of active faults, via improved earthquake locations. We will take advantage of recent work by others on large-scale waveform correlation (Waldhauser and Schaff) and the compilation of active-source data (Brocher). I will present a brief overview of the methods we have developed and examples of their application to other areas, and identify some potential target regions for study. 


\title{
APPLYING MASSIVE WAVEFORM CROSS CORRELATION AND DOUBLE- DIFFERENCE LOCATING TO NORTHERN CALIFORNIA AND CHINA
}

\author{
Schaff, D P, Waldhauser, F., and Richards, P G \\ Lamont-Doherty Earth Observatory, Columbia University, New York, NY
}

In recent years substantial advances in earthquake location have realized one to two orders of magnitude improvement over seismically broad areas due to the complementary benefits of waveform cross correlation and double-difference (DD) relative location in reducing both measurement and velocity model errors respectively. We report on results from applying these techniques on a massive scale to locally recorded seismic data across all of Northern California and to regional and teleseismic data in China. We are in the process of performing 2.5 billion correlation measurements on 280,000 events in Northern California from 1984 to present. The waveforms comprise the entire digital archive at the NCEDC recorded by 900 short period vertical component stations totaling $225 \mathrm{~GB}$ of data. We use a correlation detector instead of a correlation function to allow lags greater than $1 / 2$ of the window length (typically 1 to $2 \mathrm{~s}$ ) to be searched. At station JST, which includes 35,000 events from Bay area faults such as the Hayward, the Calaveras, and the San Andreas faults, $40 \%$ of the events have at least one other event with cross correlation coefficients (CC) greater than 0.9 (62\% for $\mathrm{CC}>0.8,77 \%$ for $\mathrm{CC}>$ 0.7). These percentages of similar events are surprisingly high, but they include known areas of repeating events on the Calaveras and San Andreas Faults. For a station in Long Valley Caldera recording 72,000 events, the distribution is $18 \%$ for $\mathrm{CC}>0.9,43 \%$ for $\mathrm{CC}>0.8$, and $67 \%$ for CC > 0.7. A station including 20,000 events in the different tectonic settings of Mendocino Triple Junction and Geysers Geothermal Fields has $16 \%$ of the events with $\mathrm{CC}>0.9$ with at least one other event, $32 \%$ have $\mathrm{CC}>0.8$, and $49 \%$ have $\mathrm{CC}>0.7$. The lower numbers of correlated events observed at the latter two stations most likely reflect the different faulting processes that take place in these areas, compared to the (mostly) strike-slip events recorded at JST. To improve the accuracy of inter-event distances from which we determine pairs of events for correlation measurements we have relocated about 240,000 events using the double-difference method together with about 5 million NCSN P-phase picks. The mean shift between routine NCSN locations and DD relocations is about 300 and $500 \mathrm{~m}$ in the horizontal and vertical directions, respectively. The relocated seismicity shows a substantially increased level of detail across most of the Northern California region, which can be significantly enhanced by incorporating the cross correlation differential time measurements, once they are available. In China, we applied cross correlation methods to seismograms recorded at regional and teleseismic distances from $\sim 14,000$ earthquakes and explosions, to measure relative arrival times to an accuracy of $\sim 0.01 \mathrm{~s}$, obtaining location precision around a few $100 \mathrm{~m}$--- approximately a hundredfold improvement over current methods. From the results it is discovered about $10 \%$ of earthquakes in and near China, reported for the period 1985 to 2000 with $M>=3$, are repeat events generating essentially the same signals from sources each of which cannot be more than about $1 \mathrm{~km}$ from another event. 


\section{Publications Resulting From NEHRP-Funded Work in Northern California}

Unruh, J.R., and W.R. Lettis, 1998, Kinematics of transpressional deformation in the eastern San Francisco Bay region, California: Geology, v. 26, p. 19-22.

Working Group on Northern California Earthquake Probabilities, 1999 Earthquake probabilities in the San Francisco Bay region: 2000 to 2030 - A summary of findings: U.S. Geological Survey OpenFile Report 99-517 (published on the World Wide Web, URL: http://quake.wr.usgs.gov/study/ wg99/of99-517/index.htm;; Unruh is one of many authors of this document)

Unruh, J.R., 2001, Characterization of Blind Thrust Faults in the San Francisco Bay Area, in Ferriz, H. and Anderson, R., Engineering Geology Practice in Northern California2: California Geological Survey Bulletin 210, p. 211-227.

\section{Guidebook Papers Resulting From NEHRP-Funded Work in Northern California}

Unruh, J.R., and Sawyer, T.L., 2001, Structure, late Cenozoic development, and seismic potential of the Mt. Diablo anticline, in Kelson, K.I., ed., Great Shakes of the Eastern Bay Area: a Ride Through the Past to See the Future: Guidebook, Seismological Society of America Annual Meeting Field Trip, $14 \mathrm{p}$.

Sawyer, T.L., and Unruh, J.R., 2001, Neotectonic aspects of the Greenville fault, San Francisco Bay area, in Kelson, K.I., ed., Great Shakes of the Eastern Bay Area: a Ride Through the Past to See the Future: Guidebook, Seismological Society of America Annual Meeting Field Trip, 7 p.

\section{Abstracts Resulting From NEHRP- and BAPEX-Funded Work in Northern California}

Unruh, J. R., 1996, Kinematics of seismogenic deformation east of the Hayward fault, eastern San Francisco Bay region, California. EOS (Transactions, American Geophysical Union) 77:(46)F742.

Sawyer, T. L., K. L. Knufsen and J. R. Unruh, 1996, Tectonic-geomorphic expression of late Quaternary folding in the Mt. Diablo-Livermore region, eastern San Francisco Bay area, California. EOS (Transactions, American Geophysical Union) 77:(46)F742.

Unruh, J.R., S.T. Hector, P.L. Williams, and J.W. Rector, 1997, Transpressional tectonics of the western Sacramento-San Joaquin Delta, eastern San Francisco Bay region, California: EOS (Transactions, American Geophysical Union) 78(45): F631-F632.

Baldwin, J.N., and J.R. Unruh, 1997, Neotectonic lineaments and Quaternary folds in the Howell Mountains, eastern Napa Valley California: Restraining step-over at the northern termination of the Green Valley fault? EOS (Transactions, American Geophysical Union), 78(45):F632.

Lettis, W.R., and J.R. Unruh, 1997, Causes of crustal shortening in the eastern San Francisco Bay region: a distinct seismotectonic domain. Geological Society of America Abstracts with Programs, 29(6):A-130-131.

Unruh, J.R., T.L. Sawyer, and J.N. Baldwin, 1999, Transpressional tectonics of the eastern Coast Ranges in central California. Geological Society of America Abstracts with Programs 31(6): A-103.

Unruh, J. R, 2000, Paleoseismic investigation of the central Greenville fault, eastern San Francisco Bay region, California Geological Society of America Abstracts with Programs 32(7): A-442.

Unruh, J.R., and Dumitru, T.A., 2001, Coupling of early Tertiary graben development in the Great Valley forearc basin with blueschist exhumation in the underlying Franciscan accretionary wedge at Mt. Diablo, eastern San Francisco Bay Area, California. Geological Society of America Abstracts with Programs, v. 33, no.3, p. A64.

Unruh, J.R., and Sawyer, T.L., 2001, Tectonic setting and seismic potential of the blind Mt. Diablo thrust fault, eastern San Francisco Bay area, California. Seismological Research Letters 72(2):p. 227. 


\section{STRUCTURE AND STRATIGRAPHY OF THE SANTA CLARA VALLEY}

C.M. Wentworth ${ }^{1}$, R.C. Jachens ${ }^{1}$, S.E. Graham ${ }^{2}$, R.W. Graymer ${ }^{1}$, R.T. Hanson ${ }^{3}$, E.A. Mankinen ${ }^{1}$, J.C. Tinsley ${ }^{1}$, and R.A. Williams ${ }^{4}$

${ }^{1}$ U. S. Geological Survey, 345 Middlefield Rd., Menlo Park, CA 94025

${ }^{2}$ U. S. Geological Survey, Flagstaff, AZ

${ }^{3}$ U. S. Geological Survey, WRD, San Diego, CA 92123

${ }^{4}$ U. S. Geological Survey, Denver, CO

The Santa Clara Valley is underlain by an alluvial basin about $400 \mathrm{~m}$ deep and less than 1 million years old that fills the southeastern end of the San Francisco Bay trough. It is bounded northeast and southwest by outward dipping reverse faults that have raised the adjacent mountains. The basement surface within the valley defines a central, northwest-trending basement high, but to both the northeast and southwest it drops beneath deep (4-6 km) flanking basins concealed by the younger alluvium.

The southwestern, Cupertino basin is an asymmetric structural depression that seismic reflection profiling indicates is filled with southwest dipping strata beneath a Plio-Quaternary unconformity at a depth of about $400 \mathrm{~m}$. These rocks are oil-bearing Miocene Monterey and possibly older Tertiary rocks (Stanley and others, 2000). In contrast, the northeastern, Evergreen basin is a pull-apart basin formed between the Silver Creek and Hayward faults that contains Miocene and younger fill. Seismic reflection profiling indicates this fill is essentially flat lying in at least the upper $1+\mathrm{km}$. The Silver Creek fault has offset that is young enough to form a groundwater boundary in the upper $175 \mathrm{~m}$ of alluvium.

Outward dipping reverse faults with late Quaternary offset at the valley margin are mapped at the ground surface and documented geophysically. We note the southwest-directed thrusts in the Evergreen basin indicated by ramp and flat structure in seismic profiles and small earthquakes that trend up to the base of the Cupertino Basin. There, groundwater modeling and seismic reflection profiling constrain the position of a blind fault outboard of the mapped faults.

The unconformable base of the Plio-Quaternary valley fill is identified from drillers logs of water wells, bedrock sampled in five deep holes, and seismic refraction and reflection profiles. Throughout much of the valley it lies at a depth of about $400 \mathrm{~m}$, but shallows northwestward toward the Dumbarton bridge and the Coyote Hills.

The alluvial fill has been explored with 8 new deep (1000 ft) drill holes. The section is largely less than $780 \mathrm{ka}$, as indicated by correlation of a magnetic reversal in cores from the holes with the Bruhnes/Matuyama paleomagnetic boundary. The section should contain unconformities associated with the numerous late Quaternary lowstands of sea level and toward San Francisco Bay should interfinger with high-stand estuarine sediments, thus providing a basis for sequence stratigraphic subdivision. The northernmost of the new drill holes seems to have encountered some of these estuarine sediments, although paleontologic confirmation has not been found. The uppermost sequence is Holocene and overlies an unconformity that has been mapped by others from geotechnical borings. This section locally reaches a thickness of more than $15 \mathrm{~m}$.

The Evergreen dense array of seismometers extends across the Evergreen basin and over the edge of the central basement high. The Holocene section thickens southwestward across the array and reaches a more stable thickness of about $12 \mathrm{~m}$ one $\mathrm{km}$ northeast of the Silver Creek fault.

$* * *$ 


\title{
OPPORTUNITIES FOR HEAT FLOW AND BOREHOLE STUDIES WITH PBO DRILLING AND RESULTS FROM SF BAY AREA MiniPBO MEASUREMENTS
}

\author{
Colin F. Williams, USGS Earthquake Hazards Team, Menlo Park, CA \\ Robert N. Harris, University of Utah, Salt Lake City, UT
}

An integral element to understanding rheology, continental deformation, evolution and geodynamics is knowledge of the subsurface thermal regime. Current plans call for the Plate Boundary Observatory (PBO) component of Earthscope to install 175 borehole strainmeters at targeted locations in the western U.S., with the majority concentrated along the San Andreas Fault (SAF) zone. Strainmeter installation involves drilling of shallow ( $<250 \mathrm{~m}$ depth) holes, and the new holes can be used for coincident heat flow and other borehole studies. The results from five boreholes, recently drilled for SF miniPBO strainmeter emplacement in the San Francisco Bay Area, California provide an example of the opportunity to collect new heat flow values within this dynamic area. These new values fill gaps in existing heat flow coverage in the central and northern Bay Area, and help constrain the role of temperature in determining the spatial and temporal pattern of deformation within this plate boundary zone.

The five boreholes vary in depth from 140 to 220 meters and penetrate Cretaceous and Jurassic age sedimentary, metamorphic and igneous rocks of the Franciscan and Salinian blocks. Temperature profiles were recorded in each borehole, and more than 200 thermal conductivities were measured on drill cuttings and core samples. Reliable heat flow values were acquired at four of the five sites and range from approximately 78 to $92 \mathrm{~mW} \mathrm{~m}^{-2}$. Average heat flow from the four new sites together with 12 previously published values from the San Francisco Bay Area is $87 \mathrm{~mW} \mathrm{~m}^{-2}$ with a standard deviation of $8 \mathrm{~mW} \mathrm{~m}^{-2}$. Overall, the new data are consistent with elevated heat flow that characterizes the California Coast Ranges and confirm the continuation of this thermal regime along both the northern segment of the Hayward fault and the section of the San Andreas fault offshore San Francisco. Locally, variations in heat flow along the SAF may reconcile along strike discrepancies between observed surface slip after the 1906 San Francisco earthquake and geodetic models for coseismic slip, through the influence of thermal conditions on the maximum depth of seismic moment release.

$* * *$ 


\section{EARLY PALEOEARTHQUAKE DATA FROM TULE POND, SOUTHERN HAYWARD FAULT, CALIFORNIA}

Patrick L. Williams ${ }^{1}$ and James J. Lienkaemper ${ }^{2}$

${ }^{1}$ P. Williams and Associates, PO Box 1492, West Tisbury, MA 02575

508-274-9618; plw3@earthlink.net

${ }^{2}$ U.S. Geological Survey, Menlo Park, CA 94025

We have developed geological evidence of ancient earthquakes through the detailed mapping of sediments deposited across a prominent trace of the Hayward fault in Fremont California. Future rupture of the Hayward fault is thought to present the single greatest source of seismic hazard to the San Francisco Bay Are. The study location is at the northern tip of Tule Pond (Tyson's Lagoon), denoted here as "the Mowry site." A discrete sequence of flood and lacustrine sediments occur along the eastern, up-slope edge of the pond. We present evidence of six earthquakes interpreted from relationships within these sediments. While the spatial evidence for these events is relatively straightforward, interpretation of these data has been hampered by challenges in sediment agedetermination. In-situe organic materials are rare or essentially absent in these sediments, and all of the ages presented here have been determined from re-deposited "detrital" charcoal. A large number of age-determinations of detrital carbon samples were thus required to develop the chronology presented here. More than forty radiocarbon measurements were obtained from the Mowry site. The record of six earthquakes from the Mowry site overlaps and complements the record of five earthquakes developed at the "Tyson" site by Lienkaemper et al., 2002. In general, the Mowry record precedes the Tyson chronology. Both sites share the historic 1868 event, and the youngest paleoearthquake at Mowry clearly overlaps the period of the Tyson record. What remains are four distinct prehistoric events from each site, although there is permissive overlap of the earliest Tyson event with a late Mowry event. Combined with the results of Lienkemper and others, the Mowry record thus completes a sequence of 8-9 earthquakes to contribute to interpretation of past and future behavior of the southern Hayward fault.

$* * *$ 


\title{
SEISMIC REFLECTION IMAGES OF THE HAYWARD AND SILVER CREEK FAULTS AND THE EVERGREEN AND CUPERTINO BASINS, SOUTHERN SAN FRANCISCO BAY AREA, CALIFORNIA
}

\author{
R. Williams ${ }^{1}$, W. Stephenson ${ }^{1}$, C. Wentworth ${ }^{2}$, R. Hanson ${ }^{3}$, J. Odum ${ }^{1}$, R. Jachens ${ }^{2}$, and R. Stanley \\ ${ }^{1}$ U.S. Geological Survey, Denver, rawilliams@usgs.gov; \\ ${ }^{2}$ U.S. Geological Survey, Menlo Park, CA; \\ ${ }^{3}$ U.S. Geological Survey, San Diego, CA 92123
}

Preliminary interpretation of $30 \mathrm{~km}$ of P-wave seismic reflection data in four profiles provides new information on the configuration of basement surfaces, sedimentary basin fill, and the location of faults within the Evergreen (EB) and Cupertino Basins (CB) located in Santa Clara Valley, and across the Hayward Fault near Fremont. Some of these data were acquired with funding from the Santa Clara Valley Water District.

Evergreen Basin and vicinity: Profile 1, which follows the Guadalupe River northwestward just west of the western edge of the EB, reveals an undulating basement surface overlain by about $400 \mathrm{~m}$ of well-layered Pleistocene and possibly Pliocene sedimentary deposits. Basement paleotopography is indicated by undulations of up to $150 \mathrm{~m}$ of relief over about 300 $\mathrm{m}$ lateral distance, with overlying beds truncated against the basement highs. Profile 2 trends northeastward and crosses the EB. A 2-km-long, and as deep as 450-m basement reflection on the western end of this profile shows $100 \mathrm{~m}$ of local relief and dips gently eastward before appearing to terminate abruptly in the vicinity of the previously inferred trace of the SCF. We interpret this basement reflection termination to be the location of the SCF. To the east, the sedimentary fill thickens abruptly with flat-lying layered reflections extending to at least $1.5 \mathrm{~km}$ depth. Bedding in a 500-m wide zone above the easternmost basement reflection is tilted and deformed, relative to reflections outside the SCF zone, but the presence of faulting is unclear. The eastern side of this profile shows basin fill that appears to be folded and faulted by a series of thrust faults emerging from below the hills on the east edge of EB. The thrust faults are not well imaged and are strongly inferred from the prominent ramp-and-flat system. The thickening and folded sediment wedge over the apparent thrust suggests motion on this feature in the Pleistocene.

Cupertino Basin: Cupertino Basin: Profile 3 is a north-south profile on the northeastern margin of the Cupertino Basin. This profile shows, at depths of 50-500 m, an 8-km-long sequence of flat-lying, laterally continuous reflections that probably represent undeformed to mildly deformed nonmarine strata of Pleistocene and/or Pliocene age. In the southern $2 \mathrm{~km}$ of the profile, these horizontal strata clearly overlie a prominent angular unconformity, below which are south-dipping reflections that extend to about $1 \mathrm{~km}$ depth and probably represent moderately deformed Miocene marine deposits. The profile crosses areas where the Cascade and Santa Clara faults are shown on geologic maps, but these faults do not appear to displace any of the reflections shown at this stage of processing.

Hayward Fault: Profile 4 is a 1.6-km long profile that crosses the Hayward fault along Alameda Creek. The data clearly show the fault abruptly truncating a strong reflection, probably basement, on the west side of the fault at about $500 \mathrm{~m}$ depth. The basement reflection does not appear to be imaged on the east side of the fault. Flat-lying reflections on the west side of the fault overlying the basement are clearly discontinuous from west dipping reflections on the east side of the fault. The angle of the discontinuity suggests a fault dipping about 70 degrees east in the upper 500 meters. 


\title{
INTRODUCTION, GOALS AND PURPOSES OF THE WORKSHOP
}

\author{
Mary Lou Zoback, USGS, Menlo Park, CA \\ NEHRP Regional Coordinator, Northern California
}

Welcome to the first annual Northern California Earthquake Hazards workshop sponsored by the USGS National Earthquake Hazards Reduction Program (NEHRP). The purpose of the workshop is to increase communication between internal and external researchers and with our user community. We hope to bring participants up-to-date on latest research results, highlight important unresolved questions and issues, and reach a consensus on short- and long-term priorities for hazard and risk reduction products and research in Northern California.

Northern California provides an unprecedented opportunity for major advances in NEHRP research, monitoring, and assessment efforts for several reasons:

- Most densely sampled (geologically \& geophysically) active seismic region in the country.

- Major contributory efforts by other USGS programs (Geologic Mapping and Coastal and Marine)

- Strong working relationships with the user community (transportation, utilities, water districts, emergency response, earthquake insurance sectors as well as state agencies and local governments)

- Active collaborations with partners at CGS, PEER, OES, FEMA, Lawrence Livermore, and the university and consulting communities

- NSF-funded EarthScope initiative will focus initial activity in central and northern California providing new seismic, GPS, and borehole strainmeter data

- Centennial anniversary of the 1906 earthquake will to focus the region's and the nation's attention on earthquake science and hazard and risk reduction products

These factors combined with the tectonic setting of northern California makes the region an ideal natural laboratory to address major NEHRP science questions:

- Fault communication and stress shadows

- Coefficient of variation/recurrence interval

- Role of creeping faults

- Soil non-linearity

- Strain/stress partitioning -- strike-slip vs. compressional

- Next generation seismic attenuation relations (with PEER, Caltrans, PG\&E, SCEC, CA Energy Commission)

All the reasons above combined with recent activities and research results make this an exciting and propitious time to better focus earthquake hazards work in Northern California. The Bay Region Earthquake probability study published in 2003 increased awareness of the hazard throughout the region and highlighted several unresolved research issues including the effect of stress shadows and the importance of fault interaction, creep behavior at depth and relationship to earthquakes, and "strength" and persistence of segment boundaries, among others. Formation of the California Integrated Seismic Network (with UC Berkeley, Caltech, CGS, and CA OES) has resulted in a uniform statewide seismic monitoring system with $\mathrm{N}-\mathrm{S}$ redundancy and a direct tie to state emergency response. Installation over the past three years of $\sim 100$ new digital strong motion stations connected by dial-up or real-time telemetry in the Bay Area as part of the USGS's Advanced National Seismic System (ANSS) allow production of ShakeMaps within minutes 
of significant events and are greatly increasing the database of ground motions for moderatesized events. Project Impact work in Oakland has produced prototype urban seismic hazard, liquefaction susceptibility and landslide hazard maps. A wealth of data from urban seismic arrays and active seismic experiments throughout the region are being used with gravity and magnetic data to define basin structure, identify young faulting and to build and test models of basin amplification. These data compliment site response studies, cone-penetrometer testing in the near surface and the recent correlation and consistent mapping of Quaternary deposits and liquefaction susceptibility for the greater Bay Area. The Bay Area Paleoseismology Experiment (BAPEX) has refined our knowledge of active faulting throughout the region is beginning to reach its goal of a developing a 2000 year history of activity on the region's main faults. This effort is complimented by a $6000+$ year chronology of major earthquakes on the San Andreas fault inferred from offshore turbidite correlations. These paleoseismic data, together with gravity, magnetic, and seismic data defining subsurface fault geometry, will help constrain physical models of long-term earthquake occurrence that can be tested against strain and deformation monitoring data that will be densified as a result of EarthScope.

One major outcome of this workshop will be to develop priorities to focus NEHRP efforts and products in Northern California. Strategies to address major unsolved questions/issues and product needs will be defined with one-year, 3-5 year, and long term (5-10 year) goals.

\section{Important web pages for USGS Northern California Earthquake Hazards products:}

Earthquake Probabilities in the San Francisco Bay Region: 2003-2032. http://quake.wr.usgs.gov/research/seismology/wg02

Project Impact urban hazard maps http://quake.usgs.gov/prepare/alameda.htm

Liquefaction Hazard and Shaking Amplification http://geopubs.wr.usgs.gov/map-mf/mf2379 seismic landslide hazard http://geopubs.wr.usgs.gov/map-mf/mf2385 susceptibility to slope failure

Real-time earthquake maps http://quake.wr.usgs.gov/recenteqs/latest.htm

CISN (California Integrated Seismic Network) http://www.cisn.org,

Real-time geodetic monitoring http://quake.wr.usgs.gov/research/deformation/monitoring/index.html

Quaternary Deposits and Liquefaction Susceptibility Maps for great SF Bay Area http://geopubs.wr.usgs.gov/open-file/of00-444,

Zoomable maps of soil type and shaking hazard in the SF Bay Area http://quake.usgs.gov/prepare/soil_type/index.html

Access to cone-penetrometer data in Bay Area http://quake.usgs.gov/prepare/cpt/

Logs and data from Tule Pond site on southern Hayward Fault http://geopubs.wr.usgs.gov/open-file/of03-488

Hayward Fault Workshop report

http://geopubs.wr.usgs.gov/open-file/of03-485

$* * *$ 


\section{Chapter 3 PANEL DISCUSSION: USER PERSPECTIVES}

Representatives of a variety of sectors in the user community provided their perspectives in a panel discussion scheduled for one and a half hours that expanded to nearly two and a half hours in response to discussion with the audience. The panel members and the agencies or companies they represented:

- David Lee, Senior Engineer, East Bay Muncipal Utilities District (EBMUD)

- Tom Horton, Group Manager, Earthquake Safety Program, Bay Area Rapid Transit (BART)

- Cliff Roblee, Chief, Geotechnical/Ground Motion Research,California Department of Transportation (Caltrans)

- Milo Pearson, Executive Director, California Earthquake Authority (CEA)

- Jim Goltz, Earthquake Specialist, California Office of Emergency Services (CA OES)

- Norm Abrahamson, Senior Research Engineer, Pacific Gas and Electric (PG\&E)

The panel members were invited to provide advice for the USGS NEHRP Program in northern California and comment on their particular earthquake hazard and risk concerns, how they view the role of the USGS in addressing these concerns, , and new products or information they would like to see. A synthesis of some of the general comments is given below, followed by summaries of each of the individual panel members presentations.

\section{Synthesis of some key points raised:}

User's biggest concerns related to earthquake hazard:

- their ability, post-earthquake, to provide continuity of essential services with a minimum of disruption

- recognition that despite their best planning and preparation, they remain vulnerable due to interdependencies/interconnectivity of infrastructure

What they look to the USGS for:

- Awareness of hazard - there was general agreement that USGS had done a good job of providing the information on earthquake likelihoods as well as seismic shaking hazard in northern California. However, there was a call for "training workshops" to explain and translate hazard products for city planners, etc.

- Expansion of hazard mapping--Users would like comparable and uniform mapping coverage for other earthquake-related hazards including landslides, liquefaction, and fault rupture. More than simply liquefaction susceptibility, end-users would like quantification of liquefaction effects (see abstract from Keith Knudsen, CGS, in Chapter 2, who although not part of the panel discussion, did comment on specific liquefaction research needs for the state's regulatory mapping) 
- Real-time data for earthquake response - modern digital sensors with broad dynamic range, advanced telecommunications, and widespread use of the internet have enabled the USGS as a part of the California Integrated Seismic Network (CISN) to immediately provide critical earthquake information post-event. Development of ShakeMap to provide mapping of measure and extrapolated ground motions has been extremely successful, it forms the basis for many CA end-users immediate post-earthquake response plans (for inspections, rerouting strategies, etc.). However, practical use has indicated the need for a number of improvements to ShakeMap capabilities including more precise source mode to supplement the actual recordings, some expression of uncertainty in the maps, as well as more robustness in delivery, including pushing ShakeMap through firewalls.

ShakeMap has created an appetite for additional near real time maps on possible secondary hazards such as the predicted area distribution and intensity of liquefaction, landslides, and fault rupture. The need for customizing alerting (e.g. for specific, user-defined geographic boundaries) was also raised.

- Role in research. Both basic and user-driven research are critical. In the basic research model, experts identify and address needs based on their research experience at the cutting edge of their fields. This model underlies how new discoveries are made and vetted into sound fundamental concepts and principles. Complementing this basic research, user-driven research engages the end-user early in the process to identify needs, then works to conver $t$ the new concepts and principals into effective tools for application by practitioners. End-users frequent are faced with basic research results by different researchers that have divergent views and are formulated using different parameters. Early and close coordination with "end users" is the key to success in applied research initiatives. This enables identification of desired research-deliverable output and formats as well as participation in the evaluation process to assure that proposed concepts and tools work for practitioners.

Users identified a number of basic research questions they would like to see addressed, most were related to enhancing our ability to predict earthquake effects, including: ground motion (influence of factors such as directivity, basin effects, hanging wall/footwall effects, near fault effects), fault offset, and liquefaction deformation (see list by Roblee, which is generally all inclusive of topics raised by other end users).

Several users lauded the USGS leadership and participation in working collaborations on focused research topics that connect researchers and end-users: such as the joint PEER-Caltrans-PG\&E-USGS collaboration on developing the Next Generation Attenuation relations for improved spectra (see abstract in Chapter 2 by Jack Boatwright describing the NGA project)Working together to address key issues, implementation of the USGS authorized "Advanced National Seismic System" to provide data as well. 
- USGS Leadership - However, beyond just the definition of earthquake hazard in northern California, these users indicated that they are looking for leadership by the USGS in a number of areas, including:

○ Integrating earthquake likelihood and hazard assessment across northern and southern California study areas and including the intervening regions.

- Establishing standards or guidelines, e.g. defining the acceptable level of risk for lifeline facilities, standardizing design criteria, and developing cost-benefit analysis.

○ Providing design-libraries of consensus-recommended sets of time histories (ground motions).

- Organizing and serving online existing geodata-while the USGS earthquake program has made tremendous strides in web-based accessibility to data over the past 5 years, much more could be done.

○ Synthesizing and maintaining community models and developing priorities for filling gaps in these models.

○ Creating, by working with FEMA through NEHRP, a forum for an integrative assessment to help us understand the impacts on a complex and interdependent infrastructure and on the diverse and very fragile social infrastructure in the Bay Region. (such an effort would include earth scientists, planners, engineers, social scientists, and emergency responders).

○ Providing support for outreach by local agencies 


\section{Summaries of Individual Presentations:}

\section{User Perspective-Utilities}

David Lee

Senior Engineer

East Bay Municipal Utility District (EBMUD)

\section{1) Awareness of hazard and risk and how EBMUD is managing it:}

EBMUD started technical studies following 1989 M6.9 Loma Prieta earthquake and developed the scope for evaluation and risk assessment:

- Seismic Evaluation Program began in 1991

- Systematic analysis to over 400 facilities-- water supply, treatment and distribution facilities

- Seismic Evaluation Program Results: January 1994

- Developed goals: protect life safety, maintain water quality, provide water for fire fighting, and minimized time to restore water service.

- Developed 4 alternative mitigation packages to meets goals

- Board adopted Seismic Improvement Program (SIP) in 1994

- $\quad$ Strong support of ratepayers

- \$189M 10-year Seismic Improvement Program began in 1995

East Bay Municipal Utility District Service Area and Active Faults

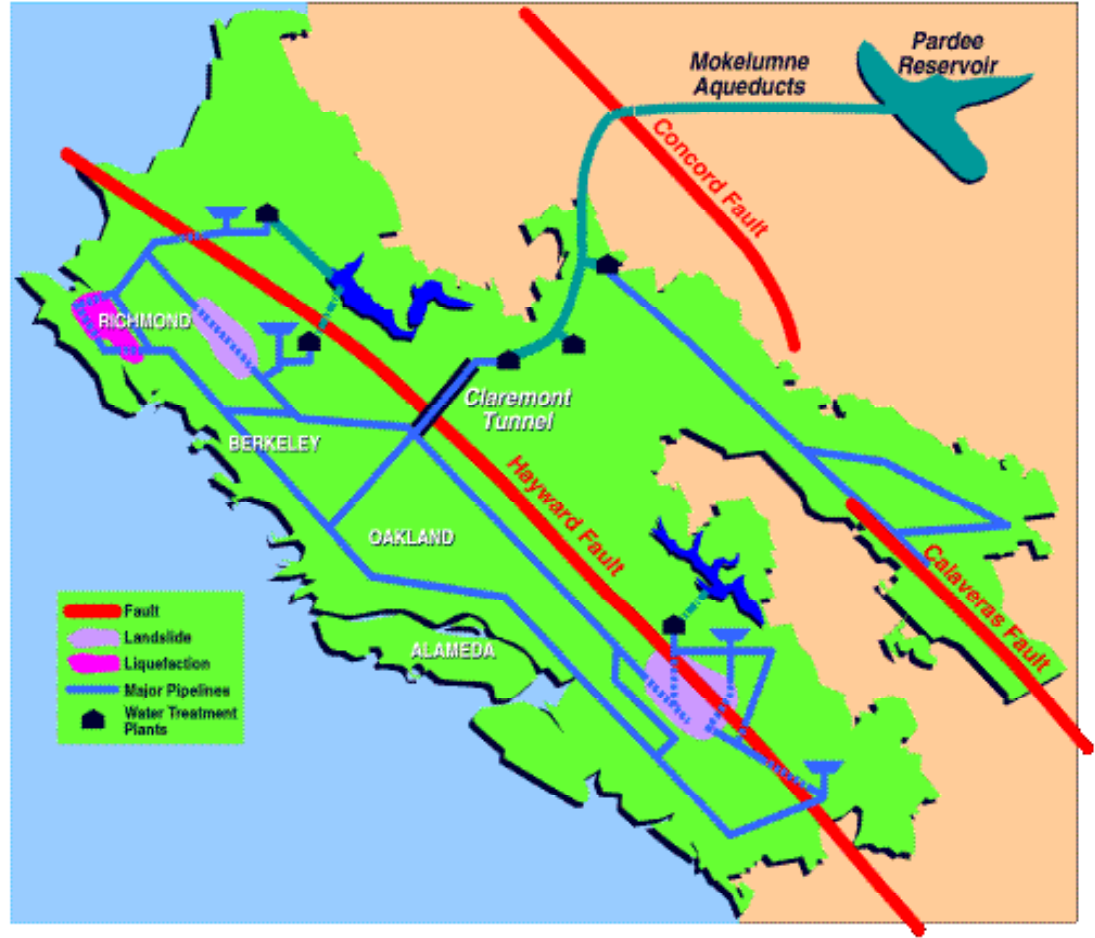




\section{Overall approach to develop Seismic Improvement Program}

- Define potential earthquake hazards

- Assess probability of post-quake functionality

- Set post-earthquake service levels/goals

- Developed four capital improvement alternatives to achieve goals

- Selected Package for Implementation

Choose four scenario earthquakes to investigate impacts:

$\begin{array}{cc}\text { Event } & \text { Magnit } \\ \text { Hayward } & 7.0 \\ \text { Hayward } & 6.0 \\ \text { Calaveras } & 6.75 \\ \text { Concord } & 6.5\end{array}$

\section{Predicted damage for Hayward magnitude 7 earthquake}

- $63 \%$ of our customers would be out of water

- Increased fire risk with $1 / 3$ of reservoirs and $2 / 3$ of pumping plants out of service

- Claremont Tunnel would be out of service

- 5,500 pipeline breaks

- 4 of 6 treatment plants would be out of service

\section{Overall mitigation goals for EBMUD}

- General goals--Life safety and Public Health

- Fire Service--Enable water availability in all service areas, especially in high fire danger zones

- Hospital and Disaster Centers--Ensure water service to locations with greater effect and vulnerable populations

- Water Service to Domestic, Commercial, and Industrial Users --Ensure potable water for drinking and hygiene

\section{Capital Improvement Program options investigated}

- Priority Package (\$13 million) - funded nearly immediately

Life safety; Reduced long-term outages

- Package \#1 (\$3 million)

Improve service after smaller earthquakes

- Package \#2 (\$84 million)

Limited service improvements after Hayward M-7

- Package \#3 (\$189 million)-selected package, funded by seismic surcharge on water bills

Improved service after Hayward M-7

- Package \#4 (\$288-\$360 million)

Low priority, low benefits—not selected 


\section{Implementation of Mitigation Package -}

- Building structures and equipment anchorage

- Strengthen buildings

- Tie-down equipment

- Water treatment Plants

- 5 of 6 water treatment plants have been structurally upgraded

- Water tank sesimic upgrade

- Shotcrete over new anchors

- Prestressed strands added to strengthen tanks

- New shotcrete cover

- Pumping plants

- Upgrade mechanical equipment and building structures so that plants can continue to supply water to higher elevation zones.

- Fault crossings

- Manual isolation valves and by-pass manifolds on pipelines

- Ability to isolate ruptured pipe and restore flow with temporary hoses

- Reinforce piping and setup flex hoses to bypass faults --Tested for emergency response with fire-fighting training

- Created southern loop pipeline (11 miles long)--connects southern part of service area to allow continued service in the event of a major quake

- Upgraded Claremont tunnel (existing tunnel was 9 feet in diameter)

- In secondary fault zone crossings--strengthen with 3 foot thick wall section and increased tunnel diameter to 12 feet to allow for continued usage following "minor" (up to 2.4 feet) of offset

- In primary fault zone crossing--increase tunnel diameter to 17 feet to accommodate up to 8.5 feet of offset. Inserted reinforced steel pipe allows water flow to continue despite offset and be protected from fallen debris.

\section{2) EBMUD Concerns Regarding Future Earthquakes}

- Life safety

- Water availability for fire fighting

- Post-earthquake customer service

- Vulnerability because of "interconnectivity" of infrastructure

- Road access to repair water facilities

- Disruption of power and communication after earthquakes

\section{3) User Needs-EBMUD perspective}

- Currently produce great earthquake probability information for the Bay Area

- Complete maps for all hazards including landslides, liquefactions, faults

- Complete next generation attenuation relations (NGA) study being carried out as part of a PEER-Caltrans-PG\&E-USGS collaboration

\section{4) How can the USGS help?}

- Organize various groups and studies for future focused collaboration and coordination - following PEER-Lifelines model connecting researchers and endusers 
- Provide leadership in establishing guidelines for acceptable risk of lifeline facilities

- Assist industry in efforts to standardize design criteria and in cost-benefit analysis

- Support local agencies in public outreach

5) How would you spend the USGS Northern California NEHRP budget if you were responsible for funding decisions?

- Take the leadership role, money is power and you are the Feds! 


\section{User's Perspective - Mass transit}

Thomas Horton

Group Manager, Earthquake Safety Program

Bay Area Rapid Transit (BART) District

BART service area and locations of active faults

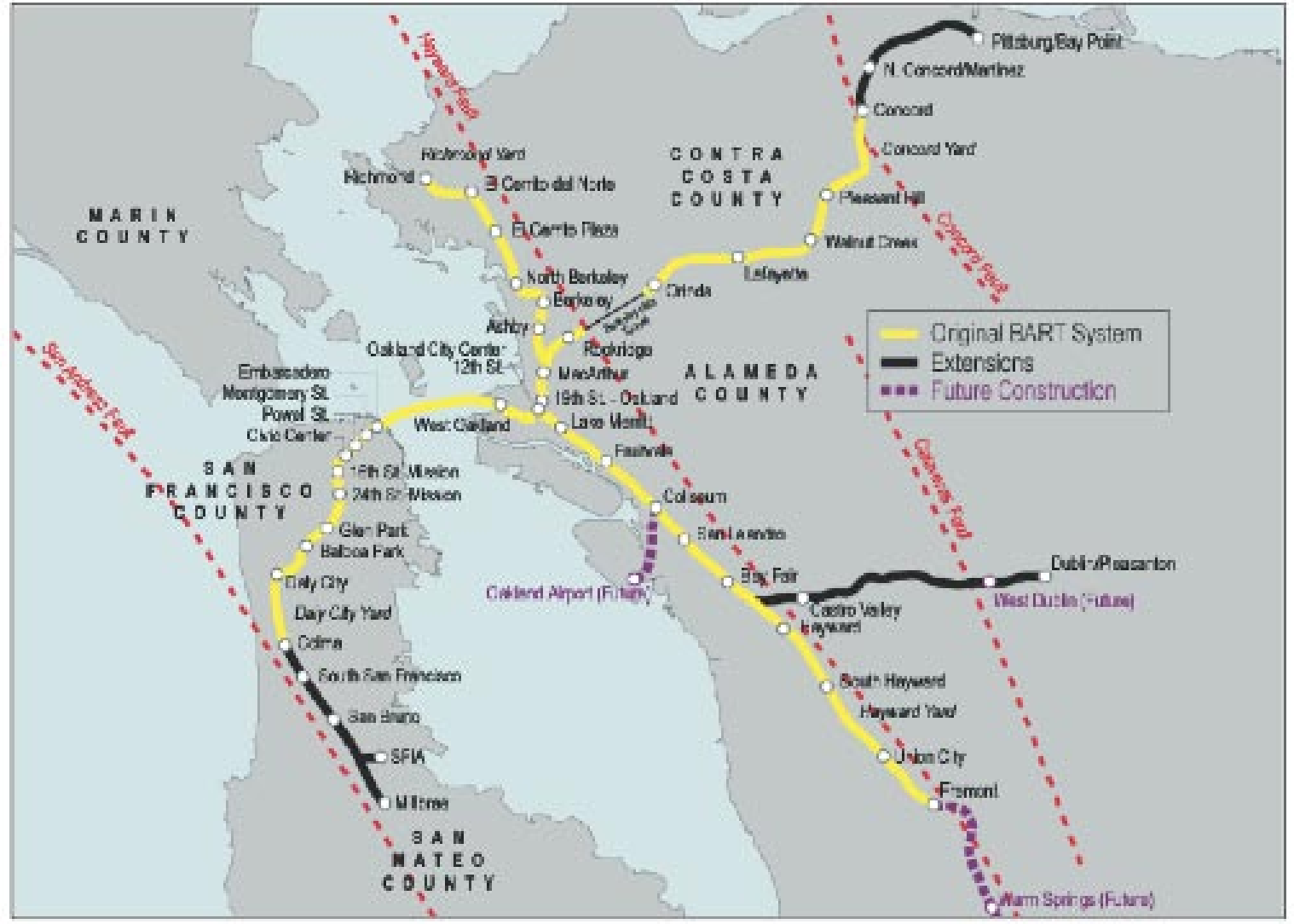

\section{User needs}

- Response spectra - we want to use spectra for design as often as possible to save design cost and time.

- Validated time histories with appropriate velocity pulses - saves the time, cost and hassle of creating new time histories for every project.

- Displacements at fault crossings - particularly at the depths/elevations where work actually takes place. Using displacement at the rock face tends to overstate the amount of displacement that will occur nearer the surface.

- Near real-time ground motions - for use in emergency response.

\section{Concerns with present ground motion information:}

- Big impact on design/retrofit concepts and costs -when there are large variations in ground motions designers tend to use the most conservative result, adding cost to the project. 
- Currently significant differences existed between "standard" models - as much as $50 \%$ variation in ground motion results at one site using different models.

- Need more consistency in approaches to get more consistent results

- Recommend more research focused on helping the users of ground motion information - provide guidance on how best to interpret results, and how to choose which analytical approach will give the most appropriate results at a given site. 


\section{User Perspective-Transportation \\ Dr. Cliff Roblee \\ Chief, Geotechnical/Ground Motion Research \\ California Department of Transportation}

Caltrans is very active in supporting applied seismic hazards research, primarily through the PEER-Lifelines (PEER-LL) program. Some key PEER-LL initiatives include:

- "Next Generation Attenuation (NGA)" for improved spectra;

- "Fault Surface-Rupture Model" for improved rupture offset estimates;

- "Design Ground Motion Library" for consensus strategies on selection and scaling of earthquake time histories for non-linear structural analyses;

- Joint Validation of PSHA Codes for improved consistency in PSHA results;

The USGS, California Geological Survey (CGS), and Southern California Earthquake Center (SCEC) are all actively participating and/or sponsoring portions of many of these projects.

The call for these projects comes primarily from design-floor experience where these issues have been shown to have significant impact. This model for research project development is sometimes termed "user driven" or "user directed" since it engages the end user early in the research process to identify needs. This model differs from the more common "principal investigator (PI) driven" research model where experts identify needs based on their research experience at the cutting edge of their fields.

Both the 'PI-driven' and the 'user-driven' research models play a vital role in achieving real advances that contribute to seismic resiliency of our infrastructure. The PI-driven model underlies how new discoveries are made and vetted into sound fundamental concepts. The user-driven model is critical to converting these new concepts into usable and effective tools for application by practitioners. The diagram below attempts to illustrate the evolution of a new research concept through development to implementation in practice. It stresses the vital, and oft-overlooked, role that the user plays in assuring implementation success.

\section{End-User's Role in Research Implementation}

(Cliff's View)

$\begin{array}{lll}\begin{array}{l}\text { Researcher } \\ \text { w/ outreach }\end{array} & \text { 0) Vacuum: } & \text { Inaccessible/Unaware } \\ & \text { 1) On-Horizon: } & \text { User Awareness and Interest } \\ \begin{array}{ll}\text { User } \\ \text { Assist }\end{array} & \text { 2) Qualitative: } & \text { Impacts User Judgment } \\ & \text { 3) Cautious Application: } & \text { Comparison } \\ \begin{array}{l}\text { Code/Policy } \\ \text { Organizations }\end{array} & \text { 4) Trusted Application: } & \text { User Preferred } \\ & \text { 5) Formal Adoption: } & \text { New Standards/Codes }\end{array}$


From the end-user perspective, new research concepts progress through a series of stages starting with vague awareness and ending with formal adoption into codes, standards and policies. Between these end members, a technical user's interest is sparked, the concept begins to impact their judgment, they begin to apply the concept cautiously on a comparative basis, they develop sufficient trust in the concept to convert from their older models, then finally, they work through the various committee processes required for code adoption.

Fundamental PI-driven research is required to identify and develop promising basic concepts. Highly educated and very specialized researchers working in an academic or government laboratory setting typically perform basic research. Typical deliverables of basic research are technical publications in professional journals. From the "end user" viewpoint, successful basic research can generate interest and even impact judgment, but it seldom yields tools that can be applied directly to problems at hand. End users frequently find basic research results by different investigators to have divergent views. Further, published results are often dispersed widely, are difficult to understand/interpret, and are presented in ways that are not readily adapted to the intended application. Using the numeric scale in the figure above, successful basic research with solid outreach programs can only be reasonably expected to bring a concept from stage ' 0 ' to stage ' 2 '.

At the other end of the implementation process are code and standards development activities. The groups and organizations that perform this work generally look only as far as well-established and trusted practices as defined by design practitioners for codification, thus moving from a stage ' 4 ' to stage ' 5 ' in the figure above. Too often, the senior-level design practitioners who participate in these activities do not incorporate the most recent research. Reasons include lack of familiarity or expertise to interpret the research literature, divergence or lack of synthesis of research findings, lack of proven application with understanding of consequences, and difficulties with a research product input requirements or output format. The 'disconnect' between the research community products and practitioners needs is sometimes referred to as an "implementation gap".

The role of 'applied research' is to span the implementation gap by converting basic research discoveries into consensus-based design tools and policies that can be implemented by practice. This might be viewed as the process of synthesizing basic research findings addressing the 'why' questions into the proven 'how to' applications needed by practicing professionals. The types of issues addressed by applied research include acquisition, organization, and synthesis of new and existing data, joint validation and application of emerging simulation procedures, pilot applications to real design problems to test the compatibility of models and data, and consensus building within the research and stakeholder communities. These activities are ultimately aimed at building user confidence for the adoption of new approaches.

Early and close coordination with 'end users' is the key to the success of applied research initiatives. Their contributions include identifying desired research-deliverable output and formats, and on-going participation in the evaluation process. The user evaluations provide 
critical early feedback to a project on whether proposed concepts and tools "work" in terms of both compatibility with information requirements and in providing useful output that is consistent with their experience. This close interaction of researcher and user is the key to spanning the implementation gap (stage ' 2 ' to ' 4 ') that will connect practice to the best emerging concepts from the research community. Caltrans is very active in precisely these types of applied research activities and looks to the broader range of infrastructure stakeholders to become active partners in these efforts.

Caltrans challenge with regard to earthquake risk and exposure--

Caltrans seismic risk needs to be considered at three levels:

- Component--primarily the capacity of bridges to withstand ground motion and ground deformation;

- Network--the connectivity and redundancy of components that defines system traffic capacity and service level;

- Operations--the ability to respond to earthquakes to quickly restore service.

\section{Caltrans Product Needs: Ground Motion}

- Design Spectra - Caltrans Design Typically Governed by large magnitude, short distance events, in the period range $\mathrm{T}=0.5$ to $2 \mathrm{sec}$

- Improved Attenuation - PEER-LL/USGS/SCEC NGA Project Underway

- Extrapolate to large M, small D using both empirical \& simulation

- Incorporate directivity pulse and fling step

- Separation of fault normal/fault parallel components

- Incorporate hanging wall / footwall

- Improved site classification

- Reduce Uncertainty

- Systematic data processing and synthesis

- Improved site characterization

- Extreme Motions in Near-Field

- Resolve whether directivity is narrow- or broad-band phenomena

- Basin Effects

- Synthesize available velocity data

- Develop regional models

- Identify areas of systematic differences in motions (from local 1-D)

- Spatial Coherence

- Important for network consideration - how likely adjacent sites will experience extreme motions

- Design Time Histories - Beginning To Be Used in Caltrans for Non-Linear Structural Analysis

- Design Library - PEER-LL/CSMIP Project Underway

- We have good databases, now we need a "design library" of consensusrecommended sets of motions for use in analysis (bins and scaling rules)

- Extreme near-field motions of greatest concern, but empirical data is sparse 
- Need reliable simulated motions or scaled empirical motions

- $\quad$ Scaling Issues

- What are the impacts of simple scaling and spectrum-matched scaling on inelastic response of structures?

- How much scaling is acceptable?

- Can far-field records be scaled to near field?

- Near Field - pulse and fling

- "Combination Rules"

- How should permanent offset (fling step) be incorporated into vibratory motion records?

- When does the maximum fling motion occur relative to the maximum dynamic motion?

\section{Caltrans Product Needs: Ground Deformation}

- Ground Deformation Hazards Are As Important To Bridge Design As Ground Shaking Hazard

- Fault Surface Rupture - Must Accommodate Large Potential Offset

- Liquefaction - Must Design Foundations To Withstand Large Lateral Forces

- $\quad$ Fault Surface Rupture Needs - PEER-LL/USGS/CGS Project Underway

- Want Model for Conditional Probability of Offset As A Function Of

- Fault type and magnitude

- Distance from mapped trace (must account for map error)

- Facility footprint size and orientation

- Variability of fault offset along strike

- Include secondary faulting

- Include fault complexity (bends, junctions, hanging wall/footwall, etc.)

- Want Simple Map Interface to Apply Model

- GIS interface for Statewide (or greater) application

- User-specified toggle between deterministic scenario (includes probability of offset conditional on event magnitude) and fully probabilistic assessment (includes event likelihood)

- Output cross-sections of displacement for specified recurrence (probabilistic) or fractile (scenario-based)

- Automatic fault parameter input for selected fault

- User-specific footprint area

- Default values for mapping uncertainty that can be over-ridden by user to account for detailed geologic survey

- Liquefaction Deformation Maps - PEER-LL/CGS Project Underway

- Want Regional-Scale (1:24000 Scale) Planning Model for Deformation Probability

- Input: Scenario or probabilistic ground motions

- Output to include free-field:

- Lateral deformation with uncertainty

- Settlement with uncertainty 
- Regional-scale tools useful for network reliability analyses. Site-specific methods are typically used for individual facilities.

- Note that Soil-Foundation-Structure Interaction (SFSI) is also a critical component of the performance of a facility, and needs to be assessed through geotechnical engineering research.

- Landslide Maps - Caltrans has pilot corridor-scale mapping project underway thru CGS)

- For network reliability analyses, want means to

- Identify most problematic slides along a highway corridor

- Estimate likelihood of having significant volumes of slide debris crossing the roadway or impacting a bridge as a function of ground shaking level

\section{Caltrans Product Needs: Earthquake Response}

- Basic ShakeMap for Response--Most useful within 1 hour, some value for 4 Hours (Value after that is primarily for forensic studies)

- Improve speed and accuracy

- Include knowledge from regional broad-band instruments

- More real-time strong-motion instruments

- Improve event modeling

- Include finite fault effects

- Include directivity

- Include hanging wall/footwall effects

- Include

- Provide uncertainty information

- Clear pre-event documentation of uncertainty and any built-in conservatism

- Provide means to plot location-specific sigma and/or fractile level, and provide updates as a function of map release

- Better coordination with CISN (current milieu is confusing to key clients)

- There are too many web sites showing same information. Work with CISN to develop uniform interface that recognizes institutional relationships and provides ubiquity for key information.

- CISN and USGS need to better coordinate efforts to assure robust delivery of and to "push" ShakeMaps thru firewalls.

- Added Features

- Develop ShakeCast tools for customized alerting and make available to broad user community

- Allow for user-specified alerting thresholds on magnitude and site-specific ground motion levels.

- Develop GIS-based administrative interface to allow institutions to pointand-click administrative boundaries over which thresholds should be set. 
- Develop near real-time maps of predicted areal distribution and intensity of possible secondary hazard

- Liquefaction

- Landslides

- Fault rupture

\section{Geo-Data Needs}

- Organize and e-Serve Existing Data

- Enhance on-line data accessibility (see PEER-LL/COSMOS GVDC effort) by providing boring logs, geophysical logs, etc. in a searchable GIS-interfacebased electronic archive.

- Particularly useful would be a public database of measured velocity profiles

- Create synthesized community models

- Create community models of subsurface conditions for all portions of the State

- Velocity model (similar to SCEC 3-D)

- Holocene contact elevation, Holocene sediment thickness, etc.

- Create visualization tools to allow users to easily navigate and view data

- Use data available from other organizations and firms

- Fill gaps in models

- Identify locations where models are poorly constrained and develop community priorities for filling the gaps. 


\section{User's Perspective - Insurance}

Milo Pearson

Executive Director

California Earthquake Authority

Earthquake Research and Hazard Product Needs

- Background on the CEA:

- Created in 1996

- Publicly managed/privately financed

- Earthquake insurance for residential structures only--no commercial

- Over 700,000 policyholders

- Insure homeowners, mobile homeowners, condos and renters

- Although these comments reflect the needs and perspective of the CEA, they also, in general, reflect the needs of the insurance industry.

- CEA has no mandate to provide for or fund research. However, historically there has been very little earthquake research related to insurance. Thus, the CEA has found research to be useful and important in these three general areas:

- Rate making

- Repair to earthquake damaged homes

- Earthquake mitigation and retrofit

- Currently the CEA funds research for post event earthquake repair (CUREE) and mitigation research (Caltech). Both of these areas are engineering-related rather than hazard.

- The new 5-year Strategic Plan for the CEA specifically references the importance of hazard research maintaining our financial strength and rate making.

- The CEA will increase its involvement in earthquake research, particularly hazard analysis.

- Here are some examples of earthquake hazard related research that the CEA considers important. Many of these ideas have been developed via discussions with various research groups, including the USGS.

- Update Southern California earthquake hazard forecast.

- Consider a statewide hazard forecast. (This is important for rate making)

- Foster better collaboration between earthquake scientists and engineers.

- Support strong motion data needs for residential structures.

- Better post earthquake data collection

- Reduce uncertainty for expected losses. 


\section{User's Perspective - Emergency Response \\ Dr. Jim Goltz \\ Earthquake Specialist \\ CA Governor's Office of Emergency Services}

\section{1) Do you feel you understand your earthquake hazard and risk?}

There is generally a good understanding of the overall hazard and risk. There is however a need for better assessments of how the region's geology impacts ground motions and building performance, and the predictability of directivity, basin effects, liquefaction and triggering of land slides. Current risk assessments and hazard mapping of liquefaction and landslide potential has limited application to land-use and emergency response planning. The area of building performance also needs work to improve the capability of loss estimation. Improvement in fragility curves, building-soil interaction, identifying, quantifying and evaluating building inventory, assessing economic losses and other societal impacts of earthquakes is also needed.

From an emergency management perspective, the developments in real-time seismology over the last decade have been critical in rapidly assessing the hazard after a damaging earthquake has occurred. The problem is that the availability of high quality and rapid data is limited to urban areas of California and other areas with high or moderate seismic risk do not have modern networks that provide such information. Even in areas where the networks provide high quality real-time data, there is the need to adequately fund programs of technology transfer and outreach to assure that the many users of this information become aware of it and can use it to optimal advantage.

2) From your personal perspective (OES) what are your biggest concerns regarding future earthquakes in Northern California?

We really do not understand the impacts of an urban earthquake on a complex and interdependent infrastructure, and on the diverse and very fragile social infrastructure in the Bay Region. The simulations and scenarios that have been used to date to describe impacts are inadequate to replicate or predict the post earthquake environment. This is an effort that will require earth scientists, planners, engineers, social scientists and emergency managers to address.

\section{3) Do you know how and where to get additional information you might need?}

Some information may exist and will need to be brought together. The real problem is that there is not a forum where the integrative process of assessment can take place. Perhaps the quarterly users meetings suggested in the session would be helpful in this regard. 
4) What new or different products/information would you like the USGS or the CA Geological Survey to provide?

If possible, it would be useful to have more quantitative assessments of risk. Building a multi-functional multi-organization model of the region's physical, economic, and social environment would also be beneficial.

Having strong motion instruments in more buildings and on or near critical infrastructure and processing data in real-time would help emergency managers prioritize damage inspection, expedite evacuations, and possibly reduce utility outage time. Collaboration among seismic, strong motion and GPS network operators would possibly enhance this capability. 


\section{User Perspective - Utilities 2}

Norm Abrahamson

Senior Research Engineer

Pacific Gas \& Electric

\section{The \#1 guiding principle for user needs-}

\section{Users need results in a format that can be directly applied}

- Typically requires more than a journal article

- Coordinated "integrating" projects are the fastest means for moving research to implementation

- Large engineering projects - results applied on specific project

- Users involved to test implementation

- Example - Next Generation Attenuation Relations (NGA) Project (PEER/

SCEC/USGS researchers)

- USGS researcher Paul Spudich developed new parameterization model for accounting for directivity effects on ground motions in Oct-Dec 2003 time frame

- This new parameterization will be implemented into attenuation relations by June 2004

- USGS report on Earthquake Probabilities for the Greater San Francisco Bay Region (2002-2031) aka "WG02"

- Developed earthquake probabilities using decision tree approach and rigorous accounting of uncertainties

- Did not go far enough toward defining hazard input for use in standard PSHA programs -could you be specific about the additional things you would like done? ** The report gives probabilities for ruptures over the next 30 years. Most engineering applications don't use 30 years. Values for 50 years would be more useful. Also, the typical input for PSHA codes is in terms of slip-rates, recurrence intervals, or annual rate for $M>5$. The values from the report can be converted to these inputs, but many users don't know how to do it. It would help to have the results converted to standard input variables (This is part of what Ned has been trying to do with his openPSHA.)

\section{Post Earthquake Products User Needs}

- Assessment of shaking from mainshock

- Generally well covered by SHAKEMAP

- Integration into users emergency response

- Assessment of shaking hazard following mainshock

- Stress-change plots

- Ground motion hazard from aftershocks (by day, week, month)

The USGS produced two products after the Dec. 22, 2003 M6.5 San Simeon earthquake which helped PG\&E decide not to defer critical maintenance at the Diablo Canyon plant 
as a result of this earthquake. First, the USGS calculated stress changes on significant neighboring faults as a result of the earthquake. The results showed that the stress driving fault motion on the Hosgri fault, the fault located closest to the PG\&E nuclear power plant at Diablo Canyon, had been reduced. Second, the USGS provided real-time information on the location of aftershocks and their rate of decay as well as the aftershock occurrence probability. PG\&E used this information to calculate the aftershock hazard a the Diablo Canyon site. (Site specific aftershock hazards are much more useful for decision makers than aftershock occurrence probabilities).

Because the power plant site was far enough from the aftershock zone, the aftershock shaking hazard indicated that the chance of damaging ground motions at the plant site was small. Also, since the rate of decay of the aftershock sequence was low, there would be little change in the aftershock hazard over a few days. Therefore, the decision was made not to defer critical maintenance at the Diablo Canyon plant as a result of this earthquake.

\section{Suggestions for USGS Products-Short-Time Frame}

- Seismograms for "scenario" M8 earthquakes

- Requires peer review of results

- USGS needs to take responsibility for simulations (e.g. after passing review, seismograms should be get "stamp of approval" from USGS)

- Ground motion models for creeping faults

- WG02 model reduces size of seismogenic rupture (patches) for creeping faults

- Standard attenuation relations may not be applicable to this case

- Deep site parameter

- Long period ( $\mathrm{T}>2 \mathrm{sec})$ response not captured by Vs30

- Need additional site term:

- e.g., depth to $\mathrm{Vs}=1500 \mathrm{~m} / \mathrm{s}$

- Consistent approach for applying site effects (amplification factors)

- Currently inconsistent hazard results for soil sites

- PSHA for rock site with soil amplification factors

- PSHA directly for soil site

To demonstrate impact of uncertainty in the attenuation relation, the following hazard curves indicate the predicted number of damaged transformers for 3 commonly used attenuation relationships. At the 0.001 level of annual probability of exceedance, the number of damaged transformers varies by a factor of 2 . 


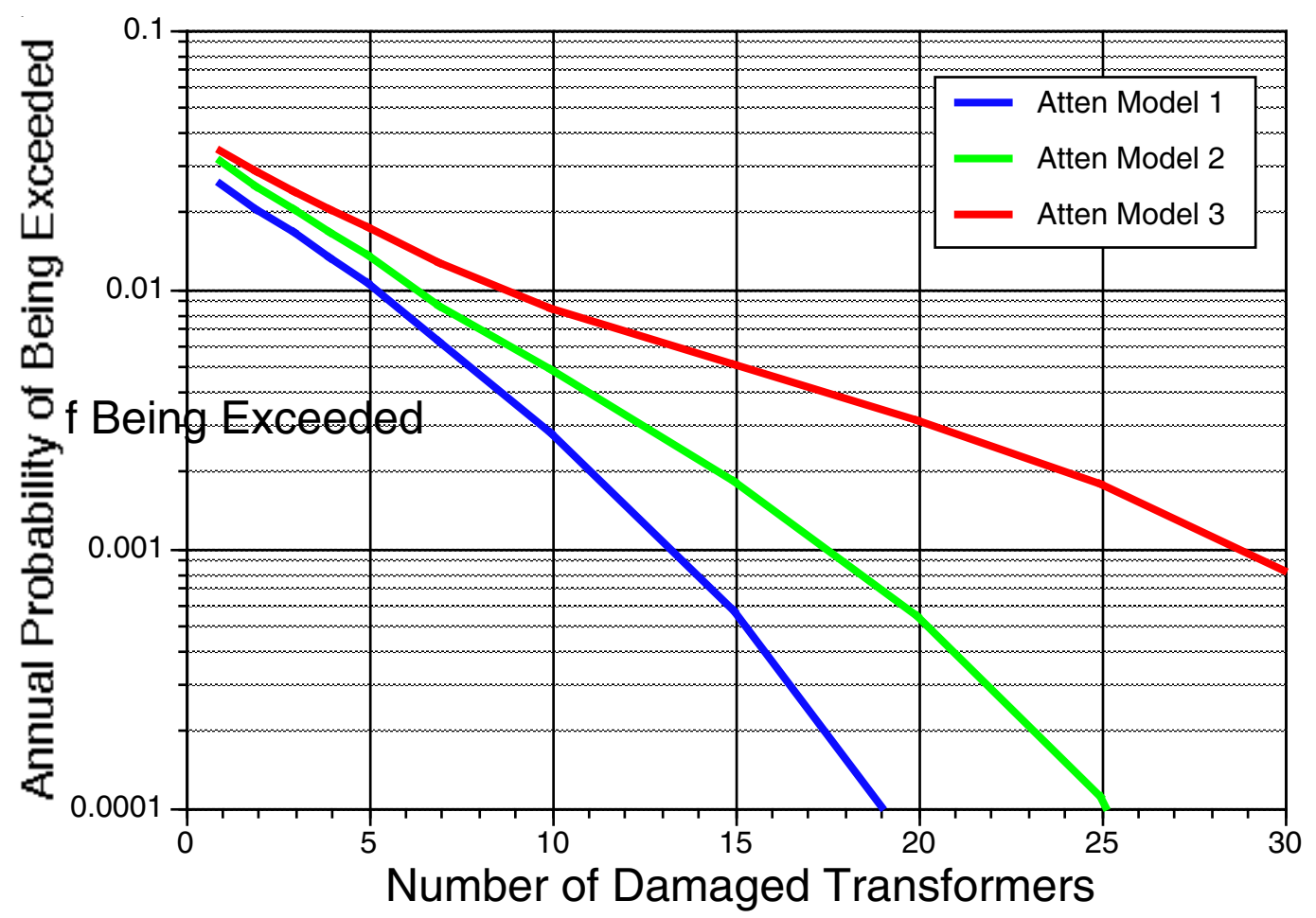

Similarily, uncertainties in source characterization outlined in the WG02 report can lead to also lead to wide range in predicted damage. These uncertainities include: time-dependent recurrence, how creep and segmentation are handled, and the magnitude-area relationship. The plot below indicates a $\pm 20-25 \%$ uncertainty in the predicted number of damaged transformers just due to the uncertainty in characterizing the time-dependent hazard.

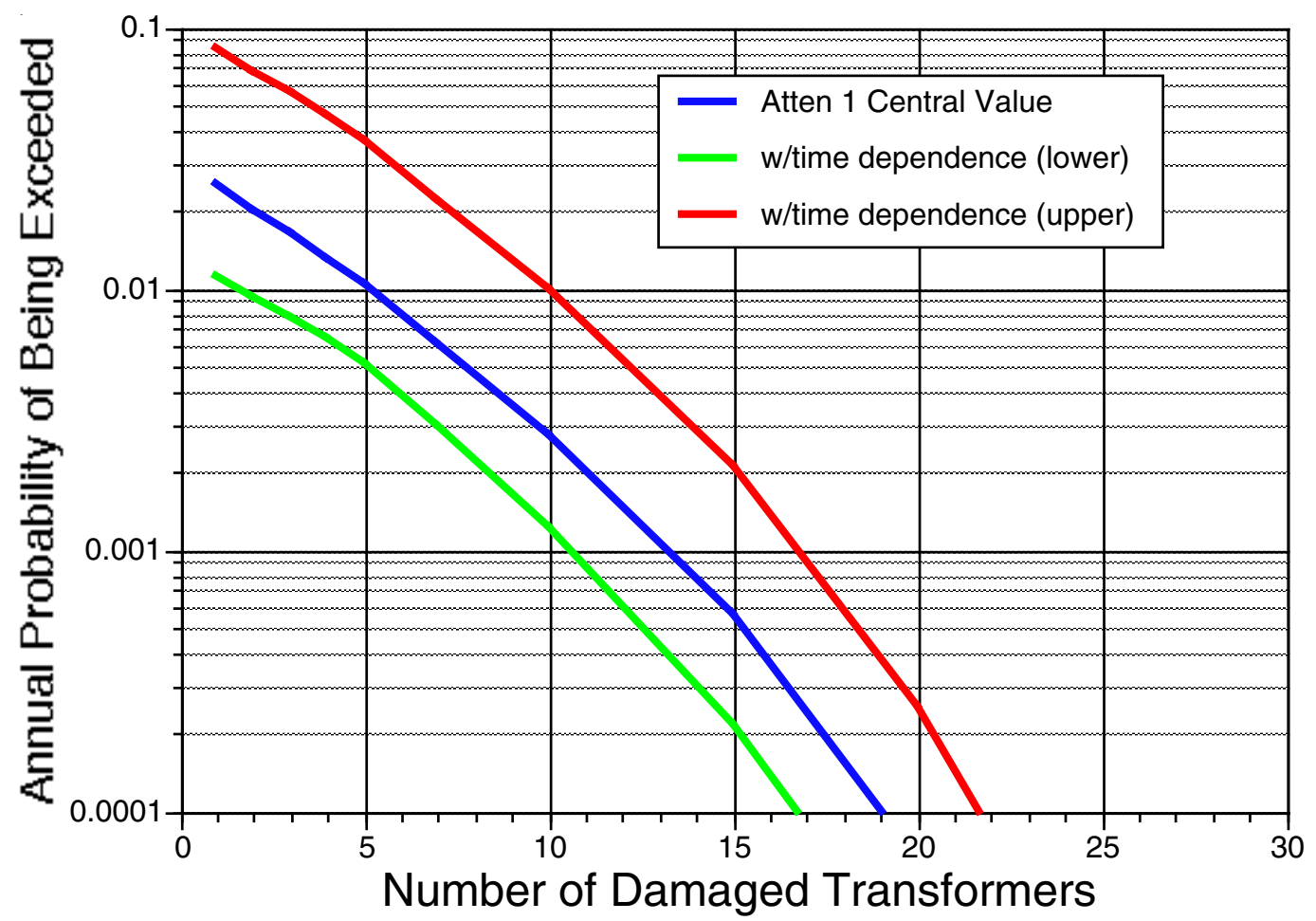




\section{User Needs--Long Term Research}

- Significant reduction in uncertainty requires data--waiting for earthquakes will not increase data set in useful time frame --need to go back in time

- Paleoseismology

- Earthquake recurrence, fault segmentation, periodicity, asperity locations(?)

- Paleoseismometry

- Geologic constraints on past ground motion-need tools besides precarious rocks

- Need major coordinated effort for collecting information on prehistoric earthquakes, e.g. rupture history for past 2000 years in. northern California 


\section{Chapter 4 PROSPECTUS FOR COMBINED USGS NEHRP NORTHERN CALIFORNIA EARTHOUAKE HAZARDS PROGRAM}

(available on the web at: http://erp-web.er.usgs.gov/NC-web.pdf)

Listed below are high-priority efforts for NEHRP research and products for the Northern California region that were identified in an open workshop held at the USGS in Menlo Park on January 13-14, 2004. Most of these efforts are on going, some with new emphases. Many require large-scale collaborations involving both internal USGS and externally funded researchers. Specific tasks within these efforts are identified below, in some cases they are categorized as short-term (to be completed in 1-2 years) and longer-term (to be completed in 3-5 years in most cases).

The highest priority for funding in the external program will be given to proposals that address these identified efforts and projects, although we always encourage submission of any creative, new ideas and projects directly applicable to a better definition of the earthquake hazard or reducing losses in northern California. It is recommended that external proposers contact the USGS researchers listed with each effort to ascertain how their proposed work can complement and help support the goals and objectives of these projects and efforts.

At current funding levels, emphasis in the Northern California hazards program will be on the highly-urbanized, greater San Francisco Bay region, extending from Gilroy in the south and Santa Rosa to the north, and from the Coast Range-Central Valley boundary on the east to the Pacific coast on the west. This region constitutes the greatest population density in Northern CA and more than 25\% of the nation's annualized risk (FEMA-366, February 2001: HAZUS99 Estimated Annualized Earthquake Loss for the United States, http://www.fema.gov/hazus/li_pubs.shtm)

This list of high-priority efforts is for a combined internal and external program, and in some cases, tasks will be carried out entirely internally. These tasks are denoted with ** in the list below.

I. Continue to upgrade and enhance capabilities and products of seismic and structural monitoring in Northern CA through the California Integrated Seismic Network (CISN).

USGS CONTACTS: David Oppenheimer (oppen@usgs.gov), Woody Savage (wusavage@usgs.gov), Mehmet Celebi (mcelebi@usgs.gov)

Short-term tasks:

1) Develop and enhance tools for automated earthquake products to be implemented by CISN in Northern California, including:-

a. cross-correlation timing/double-difference locations 
b. locations based on 3-D velocity models

c. automated computation of maps depicting static stress changes based on slip distribution models (when available) or moment tensors for smaller quakes

d. web interface to compute probablilistic probabilistic ground motions from a time-dependent model like the Jones/Weimer approach being utilized in southern Californai

e. ShakeMap-style maps of predicted areas of liquefaction] and landslide hazard immediately after a significant quake (also mentioned under hazard products.

f. regular updates to aftershock probabilities based on aftershock statistics of big quakes to be integrated with Jones/Wiemer model being utilized in southern California

2) **Convert analog USGS-funded structural and free-field strong motion and arrays in Northern California to digital instrumentation.

3) **Install direct or dial-up capability for structural and stand-alone strong motion arrays in Northern California in order to utilize these data for ShakeMap or rapid post-earthquake structural evaluation.

4) In response to the guidelines to be issued in 2004 by the national ANSS Structural Instrumentation Guideline Committee, develop a prioritized list of specific structures to instrument in Northern California.

II. Construct a community 3D seismic velocity model for northern California that can be used for seismic event locations, source mechanism determinations, sedimentary basin response calculations, and the calculation of probabilistic hazard maps. This model will be compatible with the 3D community velocity model being developed for southern California by SCEC and with the 3D geologic map being developed by the USGS for the greater San Francisco Bay region by the USGS National Cooperative Geologic Mapping Program http://3d.wr.usgs.gov/docs/wgmt/3d

\section{USGS CONTACTS: Walter Mooney (mooney@usgs.gov) and Jack Boatwright (boat@usgs.gov)}

This model will be a 3D multi-parameter physical model of the crust, including faults and seismic/lithologic boundaries. The initial 3D model will extend from Salinas north as far as Petaluma and Napa, east through the Coast Range as far as Antioch. We expect the model to be eventually extended south to encompass Monterey, north to the Geysers, and east as far as Sacramento.

This is a collaborative effort with the 3D geologic map being developed for the greater San Francisco Bay region led by Bob Jachens under the USGS National Cooperative Geologic Mapping Program. 


\section{Short-term tasks:}

1) **Adopt a suitable framework for the representation of the $3 \mathrm{D}$ model such that it can be readily accessed through the Web by all users. Develop tools for model utilization, visualization, and establish links to the database that is used to establish the model.

2) Exploit existing seismic refraction data to extract shear-wave velocities for use in model definition and particularly for the calculation of predicted ground motions for scenario earthquakes.

3) Develop a new northern California 3D tomographic model that will serve as a background model for the deeper crust, and as an initial calibration for the San Francisco Bay region 3D velocity model.

\section{Longer-term tasks:}

1) Refine Northern California 3D seismic velocity model with targeted active and passive source seismic data, including definition of seismic velocity structure within fault zones that may help constrain physical parameters.

2) Develop enhanced tools for $3 \mathrm{D}$ model verification and modification, 3D wave propagation, and model visualization. Adopt multi-parameter inversion schemes that utilize multiple seismic and geophysical data sets.

3) Expand 3D model to all regions within Northern California for which there is a priority for seismic monitoring and reporting. A second 3D model may be developed for the area encompassing Cape Mendocino and Eureka.

4) Implement high-speed computational approaches that permit model verification and modification in near-real time. Adopt truly 3D approaches to seismic event locations and source mechanism determinations using high-performance computational schemes (see Seismic monitoring effort).

5) Work with SCEC to develop an integrated 3D seismic velocity model for the entire State of California and that can be used for seismic monitoring, waveform calculation, and refined hazard assessment.

6) Provide a 3D multi-parameter physical model of the crust, including faults and seismic/lithologic boundaries, that can be used for fully $3 \mathrm{D}$ deformational modeling based on seismic slip and geodetic data for Northern California. 
III. Construct a community Quaternary fault database that will include 3D information on fault locations and slip histories. Initial implementation of the map database will be limited to the San Francisco Bay area, Santa Cruz County, and northern Monterey County. This effort will link with the USGS National Fault database and SCEC's Fault Activity database (FAD) and community fault model efforts. Results will be integrated into the 3D geologic map being developed for the greater San Francisco Bay region by the USGS National Cooperative Geologic Mapping Program:

http://3d.wr.usgs.gov/docs/wgmt/3d

USGS CONTACT: Russ Graymer (rgraymer@usgs.gov)

\section{Short-term task:}

1) Compile and evaluate existing data, and develop new information, on the surface traces, and 3-D geometry of Quaternary faults (including blind faults) and folds for incorporation into the April 2006 release of the Northern California Quaternary Fault Map Database.

2) Relocate and provide geographic coordinates for a newly-developed archive of photographs taken after the 1906 earthquake showing fault rupture, landslides, building damage, and other earthquake effects. The digital archive, assembled by UC Berkeley's Bancroft Library, will be available on the web as part of their 1906 historical database. Most of the photos were taken in San Francisco and are already located in a geographic grid. We are most interested in getting coordinates for several hundred photos taken outside of San Francisco, most of which are located by county only. We particularly encourage proposals that would involve undergraduate students in this endeavor and that would involve close coordination with USGS efforts.

\section{Longer-term tasks:}

1. Develop new information on the surface traces and 3D geometry of Quaternary faults (including blind faults) and folds that are currently poorly constrained.

2. Extend the Quaternary fault database for the entire northern California region

IV. Develop a 2000+ year slip chronology for the major active faults both onshore and offshore in northern California. This is part of an on-going effort, the Bay Area Paleoseismic Experiment (BAPEX). Study sites and results to date can be viewed at: http://quake.usgs.gov/research/paleoseismology/bapex/

USGS Contact: David Schwartz (schwartz@usgs.gov)

Tasks:

1) Determine paleoearthquake chronologies and slip-per-event, refine slip-rate and recurrence estimates, and evaluate segmentation models for major faults of the San Andreas system including the San Andreas, Hayward, Calaveras, San 
Gregorio, Concord-Green Valley, Rodgers Creek, Greenville, Maacama, and West Napa faults.

2) Determine paleoearthquake chronologies and slip-per-event, refine slip-rate and recurrence estimates, and evaluate segmentation models for surface and blind thrust faults and folds in the greater San Francisco Bay region.

Proposals are specifically encouraged for the Peninsula and North Coast segments of the San Andreas that complement a joint NSF-USGS NEHRP study to develop a paleoseismic record of the Northern San Andreas Fault from Holocene turbidite deposits off of the Northern California margin and the northern San Andreas fault Lidar data (see next item). (For information on the turbidite study, contact Chris Goldfinger at Oregon State University (gold@coas.oregonstate.edu)

V. Analyze the Lidar dataset for coastal northern California recently acquired by NASA (in collaboration with the USGS). The 418 square $\mathbf{~ k m}$ area of coverage includes a 70-km-long section of the North Coast San Andreas fault as well as a 120- kmlong stretch of coastal marine terrace. The region covered extends from near Fort Ross northward along the coast to the town of Mendocino, and inland 3-10 km. More information on this dataset, some sample images, and download directions are available at:

http://quake.usgs.gov/research/geology/lidar/

USGS contact: Carol Prentice (cprentice@usgs.gov)

\section{Short-term task:}

This Lidar dataset provides a unique opportunity to quantify and precisely map geomorphic features relevant to Quaternary fault studies. We encourage proposals that will utilize the Northern California Lidar data set as well as those that involve the development of new tools and/or techniques for quantitative geomorphic analysis that can be applied to the Lidar dataset.

VI. Utilize crustal deformation measurements to constrain the regional deformation rates, fault slip rates, role of fault creep, fault mechanics, strain transients, and models of stress evolution for northern California.

USGS CONTACT: Wayne Thatcher (thatcher@usgs.gov)

\section{Short-term tasks:}

1) Develop a Northern California GPS velocity model product.

2) **Develop a plan for operation and maintenance of the existing USGS lowfrequency deformation network in northern CA (borehole strainmeters, creepmeters, magnetometers, pore pressure transducers, and water-level monitors). Immediate problems concern upgrading instruments, modernizing telemetry, replacing failed instruments, closing down sites where geophysical return is minimal and installing new sites where expected geophysical return is optimal. 
3) **Make available to end-users in a web-accessible format fully-processed strainmeter, creepmeter, and other continuous deformation data products (including cleaned, corrected and processed multi-decade records) as well as analysis tools. Make data streams available in real-time where appropriate.

4) Develop a prototype event detection system using continuous GPS data from the Bay Area Regional Deformation (BARD) network:http://quake.geo.berkeley.edu/ bard/bard.html).

5) Augment PBO's planned strain and GPS networks by developing and/or improving creepmeter technology with the goal of low-cost, low maintenance operation, improved reliability, high long-term stability (without sacrificing shortterm precision), and ability to span greater width of fault zone than at present.

\section{Longer-term tasks:}

1) Quantify active deformation associated with areas of potential active thrust faulting and complex fault geometry such as step-overs and fault junctures (e.g., Mt. Diablo, Hayward-Calaveras juncture). This may require filling in gaps in current geodetic coverage as well as integration of GPS and InSAR analysis.

2) Utilize InSAR data to identify boundaries of active aquifers, local settling regions, relevant to near-surface fault geometry and site response issues.

3) Constrain the role of fault creep on seismic source zones and define priorities for measurements of fault creep in areas of PBO densification in northern California to study deformation and slip transients(e.g., San Andreas between San Juan Bautista and Parkfield, Maacama)

4) Develop a prototype real-time GPS processing system that can detect deformation transient of a range of durations (minutes to decades) to assist in early earthquake parameterization of source, for stress change studies, earthquake timing, triggering, and nucleation (precursors).

5) Quantify the occurrence and elucidate the role of slip transients and other deformation features that may be used in improved earthquake prediction.

6) Develop approaches to formally integrate geodetic (GPS, InSAR etc.) with seismic and geologic data

7) Develop deformation models that incorporate higher-order fault and lithosphere rheology, time dependence, stress evolution etc.

8) Develop integrated time-dependent earthquake hazard models derived from such deformation models 
VII. Develop NEHRP hazard products for Northern California with the long-term goal of producing probabilistic hazard maps (shaking, liquefaction, and landslide) that include source directivity, 3D velocity effects, non-linearity, and complete recurrence models for faults. While these products will be published by the USGS, research is needed on methodology development and validation

USGS Contact: Jack Boatwright (boat@usgs.gov)

\section{Short term tasks:}

1) Complete a series of urban hazard maps for the Santa Clara Valley

a. Create a digital site amplification map of the Santa Clara Valley that includes the effects of basin-depth, basin-edge, and non-linearity effects. This map will be linked to a web-based database of amplification data from permanent and campaign seismic stations in Santa Clara Valley.

b. Create a library of time histories and response spectra for sites within Santa Clara Valley using finite-difference models forrupture scenarios for damaging Bay Area earthquakes defined by the Working Group on Earthquake Probabilities in the San Francisco Bay Region (http://quake.usgs.gov/research/seismology/wg02/) as well as for potential moderate earthquakes in the Santa Clara valley.

c. Complete a probabilistic liquefaction hazard map and scenario hazard map for northern Santa Clara valley.

2) Develop a User guide for the Earthquake Probabilities for the San Francisco Bay Region (2002-2031) (WG02) report. This guide would help northern California municipalities fulfill federately-mandated risk assessments for their communities as stipulated by the federal Disaster Mitigation Act (DMA) 2000.

3) Convene topical workshops for the user community in Northern California to assist them in effectively utilizing USGS earthquake information and hazard products. Examples include: utilizing the results of Working Group 02 for site-specific and regional hazard assessment in northern California, effective utilization of CISN real-time earthquake products for emergency response, and reconciling inconsistent methodologies in developing design ground motions.

4) Input all geotechnical data for USGS and ANSS strong motion stations into the National Geotechnical Experimentation Sites database (http://www.unh.edu/nges) being sponsored by COSMOS. Develop methods and collect geotechnical information to model the location and amount of permanent ground deformation, including liquefaction landslides, expected from Bay Area scenario earthquakes

5) Conduct geotechnical assessments, both borehole and SASW(special analysis of surface waves) accelerograph sites that recorded the December 22, $2003 \mathrm{M}=6.5$ San Simeon earthquake. 


\section{Longer-term tasks:}

1) Create and compile maps of Quaternary geologic units in the urban Bay Area and initiate their geotechnical characterization (Mapping to be done at 1:24,000 scale and to cover the region of the preliminary map of Quaternary Deposits and Liquefaction Susceptibility Maps for the greater San Francisco Bay Area: http://geopubs.wr.usgs.gov/open-file/of00-444/). Parameters to be characterized include thickness of Holocene units, seismic wave velocities, and physical properties.

2) Create a digital site amplification map for the extended Bay Area that includes the effects of basin-depth, basin-edge, and non-linearity effects. This map will be linked to web-based database of seismic amplification data from permanent and campaign seismic stations throughout the region.

3) Develop methodologies to refine liquefaction and landslide susceptibility assessment applicable to the Bay area.

4) Develop, in collaboration with the California Geological Survey, maps showing graded liquefaction and landslide hazard, these maps would to create thresholds and subdivisions of the current "in/out" CGS hazard zoning maps.

5) Create a web-based digital library of time histories and response spectra for greater Bay Area sites from finite difference scenario models, exploiting the Bay Area 3D velocity model.

6) Develop criteria for validating hybrid and stochastic methods of generating time histories. (this effort may be part of a future USGS/PEER/SCEC collaboration).

VIII. Convene workshops to develop collaborative proposals to capitalize on deployment of the NSF-funded EarthScope MRE facility to address NEHRP Northern California earthquake hazards goals.

\section{Short term tasks:}

Develop plans and proposals to capitalize on USArray deployment and piggyback experiments in the greater Bay Area as well as complementary NEHRP efforts to collect critical data for improved NEHRP hazard evaluation.

Anticipate and plan for PBO infrastructure and data to develop complementary activities that maximize the utility of these data for NEHRP supported studies. 


\section{Appendix WORKSHOP PARTICIPANTS}

\begin{tabular}{|c|c|c|c|}
\hline Participant & First Name & E-mail & Representing \\
\hline Aagaard & Brad & baagaard@usgs.gov & USGS \\
\hline Abrahamson & Norm & NAA2@pge.com & $\begin{array}{c}\text { Pacific Gas \& Electric } \\
\text { (PG\&E) }\end{array}$ \\
\hline Abramson & Hans & HAbramson@geomatrix.com & Geomatrix \\
\hline Apel & Trey & & UC Berkeley \\
\hline Baher & Shirley & sbaher@usgs.gov & USGS \\
\hline Bakun & William & bakun@usgs.gov & USGS \\
\hline Baldwin & John & baldwin@lettis.com & Wm. Lettis \& Associates \\
\hline Barry & Rob & rbarry@water.ca.gov & $\begin{array}{l}\text { CA Div. Of Water } \\
\text { Resources }\end{array}$ \\
\hline Beroza & Gregory & beroza@stanford.edu & Stanford University \\
\hline Blanpied & Michael & mblanpied@usgs.gov & USGS \\
\hline Boatwright & John & boat@usgs.gov & USGS \\
\hline Bonilla & Doc & bonilla@usgs.gov & USGS Emeritus \\
\hline Boore & Dave & dboore@usgs.gov & USGS \\
\hline Borcherdt & Roger & borcherdt@usgs.gov & USGS \\
\hline Brocher & Tho & brocher@usgs.gov & USGS \\
\hline Bryant & Bill & bbryant@consrv.ca.gov & $\begin{array}{c}\text { California Geological } \\
\text { Survey }\end{array}$ \\
\hline Bullard & Thomas & tbullard@dri.edu & Desert Research Institute \\
\hline Burgmann & Roland & burgmann@seismo.berkeley.edu & UC Berkeley \\
\hline Caskey & John & caskey@sfsu.edu & $\begin{array}{c}\text { San Francisco State } \\
\text { University }\end{array}$ \\
\hline Catchings & Rufus & catchings@usgs.gov & USGS \\
\hline Celebi & Mehmet & celebi@usgs.gov & USGS \\
\hline Chakos & Arietta & Achakos@ci.berkeley.ca.us & City of Berkeley \\
\hline Clahan & Kevin & kclahan@consrv.ca.gov & $\begin{array}{c}\text { California Geological } \\
\text { Survey }\end{array}$ \\
\hline Craig & Mitchell & craig@csuhayward.edu & Cal State Hayward \\
\hline Crampton & Todd & Tcrampton@geomatrix.com & Geomatrix \\
\hline Croker & David & dcroker@usgs.gov & USGS \\
\hline d'Alessio & Matt & burgmann@seismo.berkeley.edu & UC Berkeley \\
\hline Dengler & Lori & lad1@humboldt.edu & Cal State Hayward \\
\hline Dreger & Doug & dreger@seismo.berkeley.edu & UC Berkeley \\
\hline
\end{tabular}




\begin{tabular}{|c|c|c|c|}
\hline Ellsworth & William & ellsworth@usgs.gov & USGS \\
\hline Evans & John R. & jrevans@usgs.gov & USGS \\
\hline Fenton & Clark & clark_fenton@urs.com & URS Corporation \\
\hline Fitzenz & Delphine & fitzenz@usgs.gov & USGS \\
\hline Fletcher & Jon B. & jfletcher@usgs.gov & USGS \\
\hline Frankel & Art & afrankel@usgs.gov & USGS \\
\hline Fuis & Gary & fuis@usgs.gov & USGS \\
\hline Fumal & Thomas E. & tfumal@usgs.gov & USGS \\
\hline Furlong & Kevin & kevin@geodyn.psu.edu & Penn State University \\
\hline Gans & Kate & kgans@usgs.gov & USGS \\
\hline Garcia & Susan & sgarcia@usgs.gov & USGS \\
\hline Gee & Lind & lind@seismo.berkeley.edu & UC Berkeley \\
\hline Geist & Eric & egeist@usgs.gov & USGS \\
\hline Goldfinger & Chris & gold@ oce.orst.edu & Oregon State University \\
\hline Goltz & Jim & jim.goltz@oes.ca.gov & $\begin{array}{c}\text { CA Office of Emergency } \\
\text { Services }\end{array}$ \\
\hline Graymer & Russ & rgraymer@usgs.gov & USGS \\
\hline Grove & Karen & kgrove@sfsu.edu & $\begin{array}{c}\text { San Francisco State } \\
\text { University }\end{array}$ \\
\hline Hanks & Thomas & thanks@usgs.gov & USGS \\
\hline Hanson & Kathryn & khanson@geomatrix.com & Geomatrix \\
\hline Hardebeck & Jeanne & jhardebeck@usgs.gov & USGS \\
\hline Harden & Deborah & harden@geosun.sjsu.edu & San Jose State University \\
\hline Harris & Ruth & harris@usgs.gov & USGS \\
\hline Hartzell & Steve & shartzell@usgs.gov & USGS \\
\hline Hecker & Suzanne & shecker@usgs.gov & USGS \\
\hline Hilley & George & burgmann@ seismo.berkeley.edu & UC Berkeley \\
\hline Hillhouse & Jack & hillhouse@usgs.gov & USGS \\
\hline Hirsch & Derrick & dhirsch@usgs.gov & USGS \\
\hline Hitchcock & Tim & hitch@lettis.com & Wm. Lettis \& Associates \\
\hline Holzer & Thomas & tholzer@usgs.gov & USGS \\
\hline Horton & Tom & thorton@bart.gov & $\begin{array}{c}\text { Bay Area Rapid Transit } \\
\text { (BART) }\end{array}$ \\
\hline Houston & Heidi & heidi@moho.ess.ucla.edu & UCLA \\
\hline Howard & J. & jhoward@water.ca.gov & $\begin{array}{c}\text { CA Div. Of Water } \\
\text { Resources }\end{array}$ \\
\hline Irwin & Porter & pirwin@usgs.gov & USGS Emeritus \\
\hline
\end{tabular}




\begin{tabular}{|c|c|c|c|}
\hline Jachens & Robert & jachens@usgs.gov & USGS \\
\hline Johanson & Ingrid & ingrid@seismo.berkeley.edu & UC Berkeley \\
\hline Johnson & Sam & sjohnson@usgs.gov & USGS \\
\hline Johnston & Malcolm & mal@usgs.gov & USGS \\
\hline Keefer & David & dkeefer@usgs.gov & USGS \\
\hline Kelson & Keith & kelson@lettis.com & Wm. Lettis \& Associates \\
\hline Knudsen & Keith & kknudsen@conservation.ca.gov & $\begin{array}{c}\text { California Geological } \\
\text { Survey }\end{array}$ \\
\hline Langbein & John & langbein@usgs.gov & USGS \\
\hline Langenheim & Vicky & langenheim@usgs.gov & USGS \\
\hline Lee & David & dlee@ebmud.com & $\begin{array}{c}\text { East Bay Municipal } \\
\text { Utilities District }\end{array}$ \\
\hline Lettis & Bill & lettis@lettis.com & Wm. Lettis \& Associates \\
\hline Lienkaemper & James J. & jlienk@usgs.gov & USGS \\
\hline Lindh & $\mathrm{Al}$ & lindh@usgs.gov & USGS Emeritus \\
\hline Lockner & Dave & dlockner@usgs.gov & USGS \\
\hline Luetgert & Jim & luetgert@usgs.gov & USGS \\
\hline Lusk & Jeff & Jeffrey.Lusk@dhs.gov & FEMA Homeland Security \\
\hline Manaker & Dave & manaker@geology.ucdavis.edu & UC Davis \\
\hline Matsuda & Ed & ematsud@bart.gov & $\begin{array}{c}\text { Bay Area Rapid Transit } \\
\text { (BART) }\end{array}$ \\
\hline McCarthy & Jill & jmccarthy@usgs.gov & USGS \\
\hline McCrory & Pat & pmccrory@usgs.gov & USGS \\
\hline McLaughlin & Robert & rjmcl@usgs.gov & USGS Emeritus \\
\hline Michael & Andrew J. & michael@usgs.gov & USGS \\
\hline Mooney & Walter D. & mooney@usgs.gov & USGS \\
\hline Moore & Diane E. & dmoore@usgs.gov & USGS \\
\hline Morrow & Carolyn A. & cmorrow@usgs.gov & USGS \\
\hline Mortensen & Carl & cmortensen@alum.berkeley.edu & USGS Emeritus \\
\hline Murphy & Janice & jmurphy@usgs.gov & USGS \\
\hline Murray & Jessica R. & jrmurray@usgs.gov & USGS \\
\hline Murray & Mark & mhmurray@seismo.berkeley.edu & UC Berkeley \\
\hline Nadeau & Bob & nadeau@ccs.lbl.gov & UC Berkeley \\
\hline Neimi & Tina & niemit@umkc.edu & $\begin{array}{c}\text { Univ. of Missouri-Kansas } \\
\text { City } \\
\end{array}$ \\
\hline Noce & Tom & tnoce@usgs.gov & USGS \\
\hline
\end{tabular}




\begin{tabular}{|c|c|c|c|}
\hline Oppenheimer & David H. & oppen@usgs.gov & USGS \\
\hline Pagenkopp & Mark & markp@water.ca.gov & CA Div. of Water Resources \\
\hline Parsons & Thomas & tparsons@usgs.gov & USGS \\
\hline Pearson & Milo & PearsonM@calquake.com & $\begin{array}{c}\text { California Earthquake } \\
\text { Authority }\end{array}$ \\
\hline Perkins & Jeanne & jeannep@abag.ca.gov & $\begin{array}{c}\text { Association of Bay Area } \\
\text { Governments (ABAG) }\end{array}$ \\
\hline Pollitz & Fred & fpollitz@usgs.gov & USGS \\
\hline Ponce & David & ponce@usgs.gov & USGS \\
\hline Prentice & Carol S. & cprentice@usgs.gov & USGS \\
\hline Ramseyer & Cynthia & cramseyer@usgs.gov & USGS \\
\hline Reasenberg & Paul A. & reasen@usgs.gov & USGS \\
\hline Reichle & Mike & mreichle@consrv.ca.gov & $\begin{array}{c}\text { California Geological } \\
\text { Survey }\end{array}$ \\
\hline Reitherman & Bob & reitherman@curee.org & CUREE \\
\hline Roblee & Cliff & cliff.roblee@dot.ca.gov & Caltrans \\
\hline Rodgers & Janice & jrodgers@usgs.gov & USGS \\
\hline Romanowicz & Barbara & barbara@seismo.berkeley.edu & UC Berkeley \\
\hline Ross & Stephanie & sross@usgs.gov & USGS \\
\hline Sarna & Andrei & sarna@usgs.gov & USGS \\
\hline Savage & Jim & jasavage@usgs.gov & USGS \\
\hline Savage & Woody & woody_savage@usgs.gov & USGS \\
\hline Sawyer & Tom & tom@piedmontgeosciences.com & Piedmont Geosciences \\
\hline Schwartz & David P. & dschwartz@usgs.gov & USGS \\
\hline Segall & Paul & segall@pangea.stanford.edu & Stanford University \\
\hline Seitz & Gordon & seitz3@earthlink.net & San Diego State University \\
\hline Shakal & Tony & tshakal@consrv.ca.gov & $\begin{array}{c}\text { California Geological } \\
\text { Survey }\end{array}$ \\
\hline Sickler & Robert & mazourka@hotmail.com & USGS \\
\hline Simpson & Robert W. & simpson@usgs.gov & USGS \\
\hline Spudich & Paul A. & spudich@usgs.gov & USGS \\
\hline Stenner & Heidi & hstenner@usgs.gov & USGS \\
\hline Stephenson & William & wstephenson@usgs.gov & USGS \\
\hline Strayer & Luther & lstrayer@csuhayward.edu & Hayward State University \\
\hline Sutter & John & jsutter@usgs.gov & USGS \\
\hline Swan & Bert & bswan@geomatrix.com & Geomatrix \\
\hline
\end{tabular}




\begin{tabular}{|c|c|c|c|}
\hline Taylor & C. D. & cdtaylor@earthlink.net & \\
\hline Thatcher & Wayne & thatcher@usgs.gov & USGS \\
\hline Thurber & Cliff & thurber@geology.wisc.edu & University of Wisconsin \\
\hline Uhrhammer & Bob & bob@seismo.berkelely.edu & UC Berkeley \\
\hline Unger & John & junger@usgs.gov & USGS \\
\hline Unruh & Jeff & unruh@lettis.com & Wm. Lettis \& Associates \\
\hline Wagner & Dave & dwagner@consrv.ca.gov & $\begin{array}{c}\text { CA Div. Of Water } \\
\text { Resources }\end{array}$ \\
\hline Walter & Steve & swalter@usgs.gov & USGS \\
\hline Ward & Steve & ward@uplift.ucsc.edu & UC Santa Cruz \\
\hline Ward & Wes & wward@usgs.gov & USGS \\
\hline Wells & Donald & DWells@geomatrix.com & Geomatrix \\
\hline Wentworth & Carl & cwent@usgs.gov & USGS \\
\hline Wicks & Charles & cwicks@usgs.gov & USGS \\
\hline Williams & Chesley & chesley.williams@rms.com & Risk Management Solutions \\
\hline Williams & Colin & colin@usgs.gov & USGS \\
\hline Williams & Patrick & plw3@earthlink.net & Independent Consultant \\
\hline Williams & R.A. & rawilliams@usgs.gov & USGS \\
\hline Wills & Chris & cwills@conservation.ca.gov & $\begin{array}{c}\text { California Geological } \\
\text { Survey }\end{array}$ \\
\hline Witter & Rob & witter@lettis.com & Wm. Lettis \& Associates \\
\hline Wong & Ivan & Ivan_Wong@urscorp.com & URS Corporation \\
\hline Zachariasen & Judy & jaz@usgs.gov & USGS \\
\hline Zoback & Mary Lou & zoback@usgs.gov & USGS \\
\hline
\end{tabular}


